UNIVERSIDADE DE SÃO PAULO

FACULDADE DE ECONOMIA, ADMINISTRAÇÃO E CONTABILIDADE DE RIBEIRÃO PRETO

DEPARTAMENTO DE CONTABILIDADE

\title{
O IMPACTO DO NÍVEL DE TRANSPARÊNCIA NO CUSTO DO CAPITAL PRÓPRIO DAS EMPRESAS DO IBOVESPA
}

LÍLIAN PEROBON MAZER

Orientador: Prof. Dr. Sílvio Hiroshi Nakao

Ribeirão Preto 
Reitora da Universidade de São Paulo:

Profa. Dra. Suely Vilela

Diretor da Faculdade de Economia, Administração e Contabilidade de Ribeirão Preto:

Prof. Dr. Rudinei Toneto Júnior

Chefe do Departamento de Contabilidade:

Profa. Dra. Maisa de Souza Ribeiro 
LÍLIAN PEROBON MAZER

\section{O IMPACTO DO NÍVEL DE TRANSPARÊNCIA NO CUSTO DO CAPITAL PRÓPRIO DAS EMPRESAS DO IBOVESPA}

Dissertação apresentada ao Departamento de Contabilidade da Faculdade de Economia, Administração e Contabilidade de Ribeirão Preto da Universidade de São Paulo, como parte dos requisitos para obtenção do título de Mestre em Controladoria e Contabilidade.

Área de Concentração: Controladoria e Contabilidade Orientador: Prof. Dr. Sílvio Hiroshi Nakao

Ribeirão Preto 


\section{FICHA CATALOGRÁFICA}

\section{Mazer, Lílian Perobon.}

O impacto do nível de transparência no custo do capital próprio das empresas do Ibovespa.

Ribeirão Preto, 2007.

101 p. : il. ; $30 \mathrm{~cm}$

Dissertação de Mestrado apresentada à Faculdade de Economia, Administração e Contabilidade de Ribeirão Preto/USP Área de concentração: Controladoria e Contabilidade.

Orientador: Nakao, Sílvio Hiroshi.

1. Contabilidade - Governança Corporativa. 2. Transparência. 3. Custo do Capital Próprio. 


\section{FOLHA DE APROVAÇÃO}

Lílian Perobon Mazer

O impacto do nível de transparência no custo do capital próprio das empresas do Ibovespa.

Dissertação apresentada ao Departamento de Contabilidade da Faculdade de Economia, Administração e Contabilidade de Ribeirão Preto da Universidade de São Paulo, como parte dos requisitos para obtenção do título de Mestre em Controladoria e Contabilidade.

Área de Concentração: Controladoria e Contabilidade

Aprovada em:

Banca Examinadora

Prof. Dr. Sílvio Hiroshi Nakao

Instituição: FEA-RP/USP

Assinatura:

Prof. Dr.

Instituição:

Assinatura:

Prof. Dr.

Instituição: Assinatura: 


\section{DEDICATÓRIA}

Aos meus pais, Rubens e Cleide, pelo amor, exemplo, incentivo e apoio incondicional. Ao Cláudio. 


\section{AGRADECIMENTOS}

Agradeço a Deus!

Quando cheguei ao final deste trabalho e olhei para trás, verifiquei que muitas pessoas tiveram participação e por isso agradeço aqui, a todos que contribuíram direta ou indiretamente, para o meu sucesso. Infelizmente não conseguirei citar todos, mas vocês são inesquecíveis e têm a minha eterna gratidão.

Ao Prof. Dr. Silvio Hiroshi Nakao, pelo apoio e orientação durante todo o trabalho, pelos ensinamentos dentro e fora do mestrado e pelo exemplo de dedicação acadêmica e amizade.

Aos meus colegas do mestrado, Adriano Nuintin, Andréa Salvi, Carlos Bonacim, Cássio Vellani, Denise Mendes, Lucileni Pereira, Maíra Assaf, Vanessa Berlato e Téssia Teixeira pelo convívio, companheirismo, apoio, aprendizado e pelos estudos partilhados dentro e fora da sala de aula.

Agradeço em especial ao meu amigo Marcelo Ambrozini pelo incentivo e contribuição, pois sem a ajuda a conclusão deste trabalho seria impossível.

Aos professores do mestrado Adriana Procópio, Alexandre Assaf Neto, Eliseu Martins, José Carlos Marion, Maísa de Souza Ribeiro, Marcelo Nagano, Roberto Vatan e Rosana Gonçalves e a todos os outros Mestres que me ajudaram a alcançar este momento.

Agradeço em especial ao professor Evandro Saidel que muito contribuiu para a conclusão deste trabalho.

À minha amiga-irmã Ana Silvia, por estar sempre ao meu lado, por partilhar comigo momentos alegres e difíceis, por me apoiar sempre e não me deixar desistir nunca.

Aos meus tios e tias que rezaram muito por mim.

Aos meus irmãos João Luís e Pedro Rubens que sempre me incentivaram.

Agradecimentos especiais dedico aos meus pais, Rubens e Cleide, por serem meu maior exemplo, pela educação, amor, apoio incondicional em todos os momentos da minha vida e pelas valiosas orações.

Por fim, ao Cláudio, meu amor, companheiro, amigo, cúmplice, por trazer ainda mais felicidade e alegria à minha vida, por sua compreensão, paciência, carinho, conselhos e apoio nos momentos difíceis. Desculpe-me por "aqueles" dias! 
“É impossível receber um abraço sem dar outro em troca. Ter falhado significa ter lutado. Ter lutado significa ter crescido." Louise L. Hay 


\section{RESUMO}

A diminuição do custo do capital das empresas por meio de um maior nível de transparência na divulgação de informações é apoiada pela literatura em duas correntes teóricas. A primeira afirma que um maior disclousure aumenta a liquidez das ações no mercado e, assim, reduz o custo de capital da organização pela redução dos custos de transação ou pelo aumento na demanda por títulos da empresa. A segunda corrente de pensamento sugere que maior transparência pode reduzir o custo de capital pela redução do risco não diversificável de estimativa. Com base nisso, o objetivo desta pesquisa é verificar a existência de relação entre o nível de transparência das empresas que compunham o índice BOVESPA na data base de 29 de dezembro de 2005 e o custo de capital próprio dessas empresas. Além das variáveis custo de capital próprio e transparência, foram usadas como variáveis de controle, o tamanho da empresa, o grau de endividamento e a relação entre o preço da ação e o valor patrimonial da empresa. Para testar a relação entre transparência e custo de capital próprio no mercado brasileiro, foi utilizada uma regressão múltipla do tipo seção transversal entre a variável dependente custo de capital e a variável independente transparência. O R-múltiplo foi de 0,3969, indicando que as variáveis do modelo são positivamente correlacionadas. No entanto, a análise do R-Quadrado mostra que apenas $15,75 \%$ da variação do custo do capital deve-se às variações das variáveis independentes utilizadas no modelo de regressão. Em linhas gerais, os resultados desse trabalho não permitem afirmar que um maior grau de transparência implica em uma redução significativa do custo de capital das empresas brasileiras no período estudado, corroborando o resultado de algumas pesquisas nacionais e internacionais levantadas na revisão bibliográfica. 


\begin{abstract}
The reduction of the costs of the companies' capital by means of a bigger level of transparency in the spreading of information is supported by literature in two theoretical chains. The first one affirms that a greater disclosure increases the liquidity of stocks in the market and, thus, reduces the cost of the organization's capital by the transaction costs reduction or by the increase in the demand for equities of the company. The second theoretical chain suggests that bigger transparency can reduce the cost of capital by the reduction of the estimated not diversifiable risk. Based on this, the objective of this research is to verify the relation between the level of transparency of the companies of which were part of the index of the São Paulo stock exchange (BOVESPA) more specifically on December 29 th of 2005 and the cost of these companies' capital. Other control variables were used; besides the cost of the companies own capital and transparency, the size of the company, the degree of liabilities and the relation between the price of shares and the equity value of the company. To test the relation between transparency and cost of the companies own capital in the Brazilian market, capital cost was used in a multiple transversal section regression between a variable dependable capital cost and the variable independent transparency. The $R$-multiple was of 0,3969, indicating that the model's variable are positively correlated. However, the analysis of R-Square shows that only $15.75 \%$ of the variation of the cost of the capital was a result of variations of the used independent variables in the regression model. As a whole, the results of this research do not enable to affirm that a bigger degree of transparency implies in a significant reduction of the cost of capital of the Brazilian companies in the studied period, confirming the result of some national and international research in the bibliographical revision.
\end{abstract}


1 FUNDAMENTAÇÃO TEÓRICA

$\begin{array}{llr}1.1 & \text { Governança corporativa } & 11\end{array}$

1.2 Marco histórico da governança corporativa $\quad 11$

1.2.1 O ativismo pioneiro de Robert Monks $\quad 12$

$\begin{array}{llr}\text { 1.2.2 O Relatório Cadbury } & 13\end{array}$

$\begin{array}{ll}\text { 1.2.3 Os princípios da OCDE } & 15\end{array}$

$\begin{array}{lll}\text { 1.3 conceito de governança corporativa } & 17\end{array}$

$\begin{array}{ll}1.4 & \text { A governança corporativa no mundo }\end{array}$

$\begin{array}{ll}\text { 1.5 A governança corporativa no Brasil } & 23\end{array}$

1.6 A BOVESPA e os níveis diferenciados de governança corporativa $\quad 26$

$\begin{array}{ll}\text { 1.6.1 Nível } 1 \text { de governança corporativa } & 28\end{array}$

$\begin{array}{ll}\text { 1.6.2 Nível } 2 \text { de governança corporativa } & 29\end{array}$

$\begin{array}{ll}\text { 1.6.3 Novo Mercado } & 30\end{array}$

1.7 Relação entre governança corporativa e transparência $\quad 33$

1.8 A questão da transparência $\quad 34$

1.9 A influência da transparência no custo de capital $\quad 39$

1.9.1 Os fatores relacionados às decisões dos gerentes sobre transparência 41

1.9.2 Consequiências da transparência na redução do custo de capital 43

1.10 Custo de oportunidade do capital $\quad \mathbf{4 4}$

$\begin{array}{lll}1.10 .1 & \text { Custo de capital } & 45\end{array}$

$\begin{array}{lll}1.10 .2 & \text { Custo do capital de terceiros } & 46\end{array}$

$\begin{array}{lll}1.10 .3 & \text { Custo do capital próprio } & 48\end{array}$

$\begin{array}{lll}\text { 1.10.4 Custo do capital total para a empresa } & 49\end{array}$

1.11 Modelos para determinação do custo do capital próprio $\quad 5$

1.11.1 Estudos sobre o custo do capital próprio no Brasil $\quad 53$

1.11.2 Metodologia de determinação do custo do capital próprio por benchmark 56

1.12 Estudos relacionados à comparação entre transparência e custo de capital 60

$\begin{array}{lll}1.12 .1 & \text { Estudos realizados no exterior } & 60\end{array}$

$\begin{array}{lll}\text { 1.12.2 Estudos realizados no Brasil } & 63\end{array}$

2 METODOLOGIA DA PESQUISA E RESULTADOS 65

$\begin{array}{llr}2.1 & \text { Composição da amostra } & 65\end{array}$

$\begin{array}{ll}2.2 & \text { Definição operacional das variáveis }\end{array}$

$\begin{array}{llr}\text { 2.2.1 Custo do capital próprio } & 68\end{array}$

$\begin{array}{lr}\text { - Taxa livre de risco } & 69\end{array}$

- Coeficiente beta $\quad 69$

- Prêmio pelo risco de mercado $r$

- Prêmio pelo Risco-Brasil $r$

$\begin{array}{ll}\text { 2.2.2 Transparência } & 71\end{array}$

$\begin{array}{lll}2.3 & \text { Variáveis de controle } & \mathbf{7 6}\end{array}$

$\begin{array}{lll}\text { 2.3.1 Tamanho da empresa } & 76\end{array}$

$\begin{array}{lll}\text { 2.3.2 Grau de endividamento } & 76\end{array}$

$\begin{array}{ll}\text { 2.3.3 Relação entre preço da ação e valor patrimonial } & 77\end{array}$

3 ANÁLISE DOS RESULTADOS DA PESQUISA

$\begin{array}{llr}3.1 & \text { Estatística descritiva } & 79\end{array}$

3.2 Análise da correlação de Pearson $r$

$\begin{array}{llr}3.3 & \text { Teste de hipóteses para correlação } & 81\end{array}$

3.4 Análise dos resultados da regressão linear múltipla $r$

$\begin{array}{llr}3.5 & \text { Teste de normalidade Kolmogorov-Smirnov } & 86\end{array}$

$\begin{array}{llr}\text { 3.6 Teste de Multicolinearidade de Farrar e Glauber } & 87\end{array}$

3.7 Análise da homocedasticidade e heterocedasticidade $\quad 90$

3.8 Teste de autocorrelação residual de Durbin-Watson $\quad 91$

4 CONSIDERAÇÕES FINAIS $\quad 93$ 


\section{LISTA DE ABREVIATURAS E SIGLAS}

ADR - American Depositary Receipt.

ANEFAC - Associação Nacional dos Executivos de Finanças, Administração e Contabilidade

BOVESPA - Bolsa de Valores de São Paulo

CAPM - Capital Asset Pricing Model

CVM - Comissão de Valores Mobiliários

DFP - Demonstrações Financeiras Padronizadas

FIPECAFI - Fundação Instituto de Pesquisas Contábeis, Atuariais e Financeiras

IAN - Informações Anuais

IASB - International Accounting Standards Board

IASC-GAAP - International Accounting Standards Committee Generally Accepted

Accounting Principles

IBGC - Instituto Brasileiro de Governança Corporativa

IBOVESPA - Índice da Bolsa de Valores de São Paulo

IPEA - Instituto de Pesquisas Econômicas e Atuariais

ITR - Informações Trimestrais

NYSE - New York Stock Exchange.

OCDE - Organização para a Cooperação e o Desenvolvimento Econômico

ROE - Return on Equity

US-GAAP - United States Generally Accepted Accounting Principles

WACC - Weighted Average Cost of Capital

YTM - Yield to Maturity 


\section{INTRODUÇÃO}

O tema transparência é de alta relevância para as corporações, já que é uma das maneiras mais importantes pelas quais os gestores se comunicam com os acionistas de uma empresa e com o mercado em geral. Tapscott e Ticoll (2005, p. 23) definem transparência como a acessibilidade, para os stakeholders, às informações institucionais referentes a assuntos que afetam seus interesses. A divulgação de informações, nesse sentido, tem papel fundamental na diminuição da assimetria informacional existente entre os grupos de interessados na empresa.

Para Hendriksen e Van Breda (1999, p. 139), a assimetria da informação pode ser entendida como uma informação incompleta, ou seja, quando as partes envolvidas em uma transação não dispõem de todas as informações desejáveis. Como exemplo, os autores citam o caso de o proprietário de uma empresa, que pode não saber quais são as preferências do administrador da mesma, seja porque o administrador tem um conjunto diferente de preferências, seja porque o administrador está deliberadamente procurando enganar o proprietário.

Da mesma forma, a transparência possui uma função de auxílio na avaliação das melhores oportunidades de alocação de recursos por parte dos investidores, já que, com base nas informações apresentadas pelos gestores, os investidores farão inferência sobre o desempenho e perspectivas futuras da empresa e tomarão a decisão de investimento em determinado empreendimento.

Ao divulgar informações com um maior nível de transparência, a empresa tende a reduzir a assimetria informacional, o que pode auxiliar na captação de recursos financeiros a um custo mais baixo. Isso porque, ao divulgar informações relevantes, os investidores terão capacidade de melhor avaliar os investimentos que estão à sua disposição, reduzindo assim o risco de erro de estimativas de retorno do seu investimento.

Por isso, o assunto transparência tem sido objeto de uma enorme gama de pesquisas, principalmente nos últimos vinte anos, dada sua crescente importância num mercado de capitais cada vez mais globalizado e competitivo, no qual os investidores têm exigido maior proteção aos seus investimentos. 
A divulgação de uma maior e melhor quantidade de informações, de forma consistente para toda a sociedade e o mercado, pode ser considerada como uma forma de igualdade de direitos entre todos os acionistas e uma forma de os gestores adquirirem credibilidade junto ao mercado. Os escândalos ocorridos recentemente envolvendo grandes empresas, principalmente nos EUA, aumentaram as discussões sobre a relevância, a credibilidade e a qualidade da divulgação de informações financeiras fornecidas aos investidores, o que torna importante estudos que exploram esse aspecto.

\section{Caracterização do problema da pesquisa}

De acordo com Hendriksen e Van Breda (1999, p. 76), a partir da década de 20, com a publicação de obras sobre a Teoria da Contabilidade e uma crescente pressão por parte do mercado, houve uma mudança do objetivo da Contabilidade, passando da apresentação de informações à administração e aos credores, para o fornecimento de informações aos investidores e acionistas. Tal mudança de objetivo levou a uma maior preocupação com as demonstrações contábeis, dando ênfase à divulgação integral de informações relevantes e de maneira uniforme.

Iudícibus (2000, p. 28) ressalta a importância da evidenciação das informações contábeis, pois, por meio da divulgação, a contabilidade consegue atingir seu objetivo principal. Dessa forma, todos os eventos que afetam ou que possam vir a afetar a situação econômica, financeira e patrimonial de uma entidade, devem ser evidenciados. Porém, cabe ressaltar que a evidenciação deve ser realizada de maneira voluntária, com informações adicionais às obrigatórias por lei, tais como estimativas de resultados futuros, demonstrações financeiras complementares, relatórios para a imprensa e outros.

Conforme dito, a assimetria informacional ocorre quando os agentes envolvidos em uma transação não possuem as mesmas informações. Dessa forma, a Contabilidade, ao fornecer informação relevante e confiável, pode exercer um papel importante na administração dos conflitos de interesse e na redução da assimetria da informação. E, um dos reflexos esperados de uma menor assimetria de informação é a redução do custo de capital. 
Alencar e Lopes (2005, p. 1) exemplificam como informação disponível e de amplo conhecimento está ligada ao custo de capital. Para os autores, como os compradores de ações não têm certeza da credibilidade dos emissores de ações, tendem a diminuir o preço da oferta que considerariam justo para essas ações. Isso funciona como um mecanismo de proteção usado pelos investidores, que tende a elevar o custo de captação por parte da empresa. Em sentido contrário, portanto, é esperado que, ao reduzir a insegurança dos investidores, munindo-os de informações relevantes, a empresa pode obter uma redução no custo desse capital.

Dessa forma, a investigação feita neste trabalho procura responder o seguinte problema de pesquisa: O nível de transparência pode afetar o custo do capital próprio da empresas brasileiras?

\section{Objetivo da pesquisa}

O objetivo desta pesquisa é verificar a existência de relação entre o nível de transparência das empresas que compunham o índice BOVESPA na data base de 29 de dezembro de 2005 e o custo de capital próprio dessas empresas.

A análise da relação entre as variáveis estudadas, mostrará se existem evidências empíricas de que empresas mais transparentes apresentam menor custo de capital próprio. Espera-se ainda contribuir para a discussão sobre transparência e custo de capital e a relação entre eles, apresentando pesquisas que representam o estado da arte sobre o tema, haja vista a crescente importância do assunto e a pouca quantidade estudos publicados sobre essa relação, especialmente no Brasil.

Alguns trabalhos com objetivo de testar a hipótese de que maior nível de evidenciação tem como efeito uma redução no custo de captação de recursos pela empresa já foram realizados anteriormente, principalmente no exterior. Por isso, essa pesquisa procura fazer uma replicação e uma extensão de outros trabalhos realizados no passado, e permitirá comparar os resultados obtidos. 


\section{Variáveis}

Além das variáveis custo de capital próprio e transparência, algumas variáveis de controle foram usadas com o objetivo de isolar sua influência sobre o relacionamento entre as variáveis. São elas: tamanho da empresa (medida pelo logaritmo neperiano da receita bruta de vendas), grau de endividamento (relação entre o Exigível Total e o Patrimônio Líquido) e a relação entre o preço da ação e o valor patrimonial da empresa (índice book-to-market).

\section{Hipóteses de Pesquisa}

De posse das informações relativas ao Custo de Capital Próprio, Transparência, Tamanho da Empresa, Endividamento e Índice Book-to-Market, foi realizado um estudo comparativo com o objetivo de verificar se existe uma relação entre essas variáveis. E, se existe, se a correlação é positiva ou negativa.

A hipótese nula (H0) é de que a correlação entre as variáveis testadas duas a duas é zero, ou seja, não existe correlação significativa entre as variáveis relacionadas. A hipótese alternativa (H1) é de que existe correlação linear significante entre as variáveis.

\section{Justificativa}

Healy e Palepu (2001) apresentaram alguns estudos relacionados ao nível de transparência da empresa, o que evidencia ser um campo de conhecimento relativamente bem desenvolvido no exterior. No Brasil, foram encontrados alguns trabalhos relacionados a esse assunto, porém, poucos estudos foram desenvolvidos no intuito de verificar a relação entre transparência e custo de capital.

De acordo com Bushman e Smith (2003, p. 68) a transparência das informações tem um papel fundamental para o bom funcionamento do mercado de capitais, pois é essencial para a avaliação das oportunidades de investimentos em uma economia, cujo papel é auxiliar investidores a alocarem seus recursos de forma mais eficiente entre as diferentes opções disponíveis no mercado. 
Nesse ponto de vista, a transparência, especialmente a voluntária, é uma ferramenta importante para as empresas se diferenciarem umas das outras, em termos de apresentarem seu desempenho, suas estratégias e metas, novos projetos de investimentos etc.

Segundo Lopes (2002), em função das condições particulares do mercado brasileiro, informações como o lucro da empresa pode ser pouco relevante para redução da assimetria de informação. Uma vez que o valor patrimonial de mercado de uma empresa (obtido pela multiplicação do total de ações emitidas e em negociação, pelo valor de mercado de cada uma delas), não é incorporado e nem divulgado pela contabilidade. Essa informação pode ser mais relevante, em termos de valor informacional, do que o lucro propriamente dito.

Esse trabalho se diferencia dos demais trabalhos realizados dentro dessa linha de pesquisa por utilizar uma amostra diferente dos encontrados na literatura, por considerar aspectos adicionais na definição de transparência, por fazer um estudo cross section de um período recente (2005) e por utilizar proxies de estimação do custo de capital próprio e da transparência empresarial diferentes dos utilizados em pesquisas semelhantes realizadas no Brasil até então.

\section{Metodologia}

O método desenvolvido nessa pesquisa é eminentemente descritivo, quantitativo e explicativo. Procura-se descrever e caracterizar com relativa profundidade os objetos em estudos, compostos por empresas brasileiras que compunham o índice BOVESPA em 29 de dezembro de 2005.

Para a descrição dessas empresas procura-se imprimir um caráter intensamente quantitativo, que permita mensurar e analisar suas características econômico-financeiras. Por fim, com a descrição e análise dessas empresas, busca-se possíveis explicações para as relações existentes entre as características de transparência dessas organizações e a relação com o custo de capital.

Para entender o caráter explicativo dessa pesquisa, busca-se embasamento no modelo teórico dos grandes temas aqui estudados. Os temas aqui abordados estão inseridos na área de 
finanças corporativas, que envolve o estudo do custo de capital e de governança corporativa, dando ênfase a um de seus princípios básicos que é a transparência.

Para Kayo (2002, p. 56), é de grande importância a formação de modelos na investigação científica, dada a dificuldade, ou até mesmo a impossibilidade de se analisar todas as conexões de uma realidade complexa. A área de Ciências Econômicas, por exemplo, é pródiga na aplicação de modelos e simplificações da realidade sob a condição do ceteris paribus. Derivada das ciências econômicas, a área de finanças faz amplo uso de modelos na tentativa de explicar as relações que influenciam os diversos tipos de decisão empresarial.

O modelo teórico contempla as teorias sobre transparência e custo de capital, que estão apresentadas no capítulo da Fundamentação Teórica. Já o modelo operacional, onde estão construídas ou operacionalizadas as variáveis utilizadas na investigação empírica - tomandose por base o que preconiza o arcabouço conceitual que forma o modelo teórico -, é apresentado no capítulo específico da Metodologia.

De acordo com Alencar e Lopes (2005, p. 1), há uma grande dificuldade em se fazer estudos que relacionam nível de transparência com custo de capital, uma vez que nenhuma dessas duas variáveis é diretamente observável. Portanto, a qualidade das conclusões dependerá, em grande parte, da habilidade do pesquisador em escolher as proxys adequadas para essas variáveis.

A amostra deste trabalho é composta por empresas que compunham o índice da Bolsa de Valores de São Paulo (BOVESPA) em 29 de dezembro de 2005, sendo a variável que representa o nível de transparência um conjunto de quatorze questões apresentadas no capítulo de Metodologia. Como representação da variável custo de capital próprio, foi utilizado o modelo do Capital Asset Pricing Model - CAPM. Como variáveis de controle adicionadas ao modelo de regressão múltipla, foram utilizadas o tamanho da empresa, o nível de endividamento e grau de conservadorismo. Por fim, as variáveis foram submetidas a um tratamento estatístico para teste de hipóteses elaboradas.

\section{Estrutura do trabalho}


No capitulo 1, "Fundamentação Teórica", é apresentada a revisão bibliográfica das teorias que formam a base deste estudo. Os principais temas abordados são governança corporativa, transparência, custo de capital. No capítulo 2, "Metodologia da Pesquisa e Resultados", são explicados os procedimentos que conduziram a investigação empírica feita neste trabalho. No capítulo 3, "Análise dos Resultados da Pesquisa", são descritos resultados encontrados bem como os testes estatísticos aplicados. E, no capítulo 4, são apresentadas as "Considerações Finais" desta pesquisa. 


\section{FUNDAMENTAÇÃO TEÓRICA}

A evidenciação de informações corporativas relevantes é um aspecto fundamental para o bom funcionamento do mercado de capitais e, conseqüentemente, para a economia de uma nação como um todo. Isso porque, investidores racionais têm aversão ao risco, e a transparência na evidenciação contábil-financeira atua na redução desse risco.

Nesse âmbito, a evidenciação tende a reduzir os efeitos da assimetria informacional entre investidores de recursos - acionistas - e tomadores de recursos - empresários. Isso porque, os proprietários das empresas possuem muito mais as informações relevantes para estimar o valor da empresa e o seu efetivo potencial de retorno em comparação com o investidor externo. Este, por sua vez, possui informações limitadas a respeito da corporação, muitas vezes restritas aos demonstrativos financeiros emanados pela Contabilidade.

Dessa forma, a Governança Corporativa surge para reduzir esse conflito de interesses, descrito na literatura econômica como conflito de agentes. Jensen e Meckling formalizaram a Teoria da Agência em 1976. Segundo essa teoria, os administradores de uma empresa (chamados de agentes) e os acionistas da organização (chamados de principais) possuem interesses divergentes e tenderão a agir de acordo com os interesses próprios.

Os conflitos de Agência surgem na medida em que as organizações se tornam maiores e começa a haver uma separação entre propriedade e gerência. A base de todos os conflitos está no fato de os administradores (gestores) possuírem interesses que se choca com os dos acionistas (proprietários). Por exemplo, a maximização do lucro no curto prazo pode ser desejada pelos gestores para aumentarem suas bonificações enquanto que os proprietários podem estar preocupados com a continuidade da empresa no médio e longo prazo, como forma de garantir seus rendimentos futuros.

Com o surgimento da Governança Corporativa, alguns mecanismos capazes de minimizar esse conflito de interesses tanto internos quanto externos à organização foram criados, conforme serão vistos a seguir. 


\subsection{Governança corporativa}

A Governança Corporativa surgiu a partir da necessidade de se criar mecanismos para solucionar os conflitos de Agência existentes nas organizações empresariais. Por meio de um conjunto de normas e diretrizes, as práticas da Governança Corporativa objetivam um maior controle e monitoramento da atividade empresarial, melhorando o relacionamento entre a gerência da companhia, os acionistas, os conselhos de administração e todos os stakeholders envolvidos no negócio.

Para Claessens et al. (2002), o desenvolvimento da governança corporativa está ligado ao próprio desenvolvimento econômico das nações e, ao adotar melhores práticas de governança corporativa, as empresas passam a ter maior acesso às instituições financiadoras de seu desenvolvimento, já que o risco associado à sua atividade passa a ser menor, o que implica na redução do seu custo de captação.

A expressão governança corporativa foi empregada pela primeira vez em $1991 \mathrm{com}$ algumas das melhores práticas definidas no ano de 1992. O primeiro livro a tratar especificamente desse assunto, Corporate Governance de R. Monks e N. Minow foi lançado em 1995. No entanto, toda a teoria que dá suporte aos mecanismos de controle e monitoramento que são recomendadas nas práticas de Governança Corporativa, advém desde a década de 1930 quando Berle e Means apresentaram o clássico problema da Teoria da Agência no artigo entitulado The Modern Corporation and Private Property.

\subsection{Marco histórico da governança corporativa}

Naquele momento, começava a se desencadear os processos de pulverização do capital e de separação da propriedade e da gestão. Nesse sentido, Andrade e Rossetti (2004, p. 56) apresentam pelo menos três marcos históricos que são importantes por sintetizar, em ordem cronológica, fatos históricos que se constituíram nos pilares da moderna Governança Corporativa. São eles:

- $\quad \mathrm{O}$ ativismo pioneiro de Robert Monks; 
- O Relatório Cadbury;

- Os Princípios da OCDE (Organização para a Cooperação e o Desenvolvimento Econômico).

\subsubsection{O ativismo pioneiro de Robert Monks}

Robert Monks foi um acionista de uma empresa norte-americana que se sentia inconformado com a omissão dos proprietários em relação a boa gestão da corporação e que começou a questionar ativamente as práticas adotadas pelos gerentes da companhia, que eram conflitantes com os interesses dos acionistas. Advogado formado em Harvard e com grande experiência do mundo corporativo, Monks detectou enormes distorções na forma como as companhias eram governadas causadas pelo fato de que o destino das companhias não eram traçados pelos seus proprietários, mas sim pelos executivos que as administravam.

Além disso, Monks alertou para a falta de transparência que as empresas possuíam e sugeriu uma maior intervenção de órgãos reguladores poderia melhorar os padrões de evidenciação das corporações, auxiliando na melhor alocação de recursos no mercado de capitais. Não demorou para que Monks conquistasse vários acionistas com as mesmas preocupações que a sua, principalmente grandes fundos de pensão americanos, e isso lhe deu maior poder de negociação com a direção das empresas.

Em 1992, Robert Monks constituiu um fundo de investimento voltado para empresas em dificuldades financeiras. Utilizando uma forma agressiva de administração, Monks mostrou na prática que suas idéias não eram simplesmente utopias sociais. Agindo da forma como ele preconizava na teoria, principalmente por meio de um monitoramento constante dos gestores, conseguiu recuperar corporações, produzindo resultados positivos e aumentando o valor de suas ações. O desempenho do seu fundo, composto de 25 corporações, chegou a superar a valorização das ações do índice Standard \& Poor's 500.

De acordo com Andrade e Rossetti (2004, p. 62), Monks capitalizou diferentes pontos de vista moldados na arena do ativismo transformando-os em ações pontuais e eficazes, amarradas a um propósito central - o de levar o acionista para os conselhos das corporações, fazendo-o 
participante dos processos decisórios. Para ele, a falta de envolvimento do proprietário passivo criou a hegemonia dos administradores, fazendo que os acionistas perdessem sua face e se tornassem desconhecidos dos administradores.

Tendo essa consciência, Monks atuou em várias frentes, entre elas incitando uma maior participação dos fundos de pensão na cobrança pela maximização do valor das empresas em que possuíam participação, além de uma forte atuação nas empresas em que era acionista entre elas a gigante do varejo americano Sears. Os resultados obtidos por Monks vão desde revelações de desvios nas práticas corporativas e exposição de falhas na legislação até um refinamento da capacidade técnica dos proprietários.

Porém, o maior legado de Monks foi a mobilização dos acionistas minoritários e institucionais na defesa dos seus interesses. Isso propiciou um maior respeito pelos direitos dos proprietários e forneceu as bases da institucionalização das práticas de Governança Corporativa.

\subsubsection{O Relatório Cadbury}

Na Inglaterra do início dos anos 1990, os conselhos de administração das corporações eram constituídos por pessoas que participavam do conselho de um grande número de companhias. Esse fato fazia com que os conselheiros se comportassem como velhos e bons amigos, que atuavam mais no sentido de atender interesses próprios do que defender as reivindicações dos acionistas minoritários. Isso gerou um clima de insatisfação crescente, que deu início a fortes pressões por parte de grupos de acionistas que acabaram tendo grande repercussão local.

Dessa forma, foi estabelecido um comitê, no início da década de 1990, com objetivo de elaborar um Código de Melhores Práticas de Governança Corporativa, constituído por representantes da Bolsa de Valores de Londres e do Instituto de Contadores Certificados. A coordenação desse comitê foi confiada a Adrian Cadbury, que já possuía um histórico de envolvimento com práticas empresariais profissionais. 
Esse comitê divulgou em 1992 um documento que reunia um conjunto das melhores práticas de Governança Corporativa, conhecido como Relatório Cadbury, que atingiram em cheio a forma como vinham sendo governadas as corporações britânicas. De acordo com Andrade e Rossetti (2004, p. 72), as práticas de governança corporativa recomendadas influenciaram efetivamente a alta gestão das corporações no Reino Unido e serviram de base para posições semelhantes em outros países. Como diferenças relevantes das propostas de Monks, o Relatório Cadbury preconizava:

- O encorajamento de um papel mais ativo nas empresas por parte dos investidores institucionais;

- O fortalecimento dos canais de comunicações entre os acionistas, os conselheiros e a direção executiva;

- Maior envolvimento do governo no sentido de incorporar os princípios de boa governança corporativa na legislação.

Assim, observa-se que, no tocante ao fortalecimento dos canais de comunicação, os instrumentos que possibilitam à empresa prestar informações com maior grau de transparência assumem um papel de grande importância. O disclosure atua então como um redutor da assimetria informacional, que além de auxiliar a melhor alocação de recursos por parte dos investidores institucionais, permite uma redução do custo de captação por parte das empresas, objeto deste estudo.

Para Schadewitz e Blevins (1995, p. 44), a transparência na evidenciação de informações empresariais permite que os potenciais riscos existentes nas organizações sejam percebidos por parte dos investidores racionais, que evitarão assumir posições acionárias e realizar investimentos financeiros em companhias cuja quantidade e qualidade da abertura de informações estão abaixo das expectativas.

No tocante a importância da informação contábil-financeira no contexto da governança corporativa, Bushman e Smith (2003) defendem que, tanto para os próprios gestores tomarem decisões sobre um projeto de investimento quanto para os investidores decidirem sobre um projeto de alocação de recursos entre as opções disponíveis, a informação contábil-financeira da empresa e de seus concorrentes é essencial. 
Porém, a governança corporativa possui um marco mais recente e de maior alcance, impulsionado principalmente pelo crescimento dos negócios corporativos, pelo amadurecimento do mercado de capitais e pela globalização entre as nações, que será visto a seguir.

\subsubsection{Os princípios da OCDE}

O terceiro grande marco da Governança Corporativa foi estabelecido por uma instituição multilateral, a Organisation for Economic Co-operation and Development, a sigla em português é OCDE - Organização para a Cooperação e o Desenvolvimento Econômico -, que congrega os 29 países industrializados mais desenvolvidos do mundo e que, desde a metade dos anos 90 vinha se interessando pelas boas práticas de governança corporativa.

Vários foram os fatores que despertaram o interesse da OCDE por questões de governança corporativa. A eliminação de barreiras econômicas entre as nações, por exemplo, aumentou a consideravelmente a competição por investimentos estrangeiros. Ciente disse, a OCDE pregava que países que adotassem práticas de governança, tais como padrões rigorosos de contabilidade e proteção aos acionistas minoritários, teriam preferência no investimento de recursos financeiros para suas corporações.

Dessa forma, Andrade e Rossetti (2004, p. 74) reiteram que a missão do grupo criado pela OCDE foi a de desenvolver princípios que ajudassem os países-membros em seus esforços de avaliação e de aperfeiçoamento institucional da boa governança corporativa. Isso traria benefícios tanto para as companhias de capital aberto quanto para as empresas de capital fechado. Os princípios foram concisos, compreensíveis e acessíveis permitindo a formação de uma base comum aplicável pelos países-membros e não-membros com interesses em adotar melhores práticas de governança corporativa.

O grupo de governança corporativa da OCDE concluiu seu trabalho em maio de 1999. No entanto, de acordo com a OCDE (2004, p. 100), com base nos debates realizados no seio do grupo de orientação, no estudo por ele realizado sobre a evolução da situação nos EstadosMembros da OCDE e nos comentários recebidos durante a ampla série de consultas, concluiu- 
se que os Princípios de 1999 deveriam ser revistos, de modo a tomar em consideração acontecimentos recentes e novas preocupações.

Depois de revistos, foram definidos alguns princípios. O primeiro deles visava assegurar a base para um enquadramento eficaz do governo das sociedades, com o objetivo de promover mercados transparentes e eficientes. Isso seria possível por meio de uma divisão clara das responsabilidades das autoridades de supervisão, das autoridades reguladoras e das autoridades dedicadas à aplicação de leis.

Outro princípio revisto, de acordo com a $\operatorname{OCDE}$ (2004, p. 18), foi com relação aos direitos dos acionistas e funções fundamentais de exercício dos direitos. Para a OCDE, o enquadramento do governo das sociedades deveria proteger e facilitar o exercício dos direitos dos acionistas. Além disso, o governo deveria assegurar o tratamento eqüitativo de todos os acionistas, incluindo acionistas minoritários e acionistas estrangeiros.

Em relação ao papel dos outros sujeitos com interesses relevantes no governo das sociedades, a OCDE afirmava ser fundamental que o governo das sociedades deveria acautelar os direitos legalmente consagrados, ou estabelecidos por meio de acordos mútuos. Também deveria encorajar uma cooperação ativa entre as sociedades e esses sujeitos na criação de riqueza, de emprego e na manutenção sustentada de empresas financeiramente saudáveis.

No tocante à divulgação de informação e transparência, a $\operatorname{OCDE}(2004$, p. 22) defendia que o governo deveria assegurar a divulgação clara e objetiva de todas as informações relevantes relativas à sociedade, principalmente no que dizia respeito à situação financeira, desempenho, participações sociais e governo da empresa.

Por fim, com relação às responsabilidades dos órgãos da administração, a OCDE propunha o enquadramento do governo no sentido de assegurar um acompanhamento e fiscalização eficazes da gestão pelo órgão de administração e a responsabilização do órgão de administração perante a empresa e os seus acionistas.

De maneira geral, conforme resumidos por Andrade e Rossetti (2004, p. 75), os princípios da OCDE visam assessorar governos membros e não-membros em seus esforços de avaliação e aperfeiçoamento da estrutura jurídica e regulatória para a Governança Corporativa em seus 
países, além de proporcionar orientação e sugestões para bolsas de valores, investidores, corporações e outras entidades que desempenham algum papel no processo de desenvolvimento da boa Governança Corporativa.

\subsection{O conceito de governança corporativa}

A Governança Corporativa, como um conjunto de princípios e práticas que tem sido incorporado aos modelos de gestão das empresas, tem atraído a atenção de diferentes partes interessadas. E, apesar da diversidade conceitual, há um conjunto bem definido de expressõeschaves, ligadas aos princípios, modelos, práticas, mecanismos de regulação e aos propósitos da Governança Corporativa.

Existem várias definições diferentes para o termo governança corporativa. Porém, apesar dos diversos conceitos existentes, eles podem ser reunidos em quatro agrupamentos, conforme proposto por Andrade e Rossetti (2004, p. 23). Cada um desses quatro agrupamentos de definições de governança corporativa possui alguns conceitos em comum.

O primeiro conjunto de definições enfatiza os direitos dos agentes envolvidos na organização e o sistema de relações existentes nas corporações. O Instituto Brasileiro de Governança Corporativa (IBGC) pode ser classificado nesse agrupamento. Para o IBGC (2006):

"A Governança corporativa é o sistema pelo qual as sociedades são dirigidas e monitoradas, envolvendo os relacionamentos entre Acionistas/Cotistas, Conselho de Administração, Diretoria, Auditoria Independente e Conselho Fiscal. As boas práticas de governança corporativa têm a finalidade de aumentar o valor da sociedade, facilitar seu acesso ao capital e contribuir para a sua perenidade."

Já um segundo conjunto de definições de governança corporativa dá ênfase nos sistemas de governo e estruturas de poder. Como exemplo, pode-se citar a definição do Relatório Cadbury que define governança corporativa como um sistema e uma estrutura de poder que regem os mecanismos através dos quais as companhias são dirigidas e controladas. 
O próprio Relatório Cadbury apresenta uma outra definição de governança corporativa que chama a atenção para sistemas de valores e padrões de comportamento. Nesta definição, a governança corporativa é expressa por um sistema de valores que rege as organizações, em sua rede de relações internas e externas, que reflete os padrões da companhia e, por conseguinte, os padrões de comportamento da sociedade como um todo.

Um quarto e último agrupamento de definições de governança corporativa são aquelas que enfocam os sistemas normativos. A definição de Monks e Minow ilustra bem essa vertente. Para eles, a governança corporativa trata do conjunto de leis e regulamentos que visam assegurar os direitos dos acionistas das empresas, disponibilizar informações que permitam acompanhamento das decisões empresariais, observância dos direitos dos stakeholders e promoção da interação dos acionistas, conselhos de administração e direção executiva das organizações.

A figura 1 resume esses quatro conjuntos de conceitos por meio dos elementos-chaves da Governança Corporativa. Este trabalho, por sua vez, concentra-se no sistema de valores, que são os princípios fundamentais que dão sustentação à boa Governança Corporativa, dando destaque à transparência.

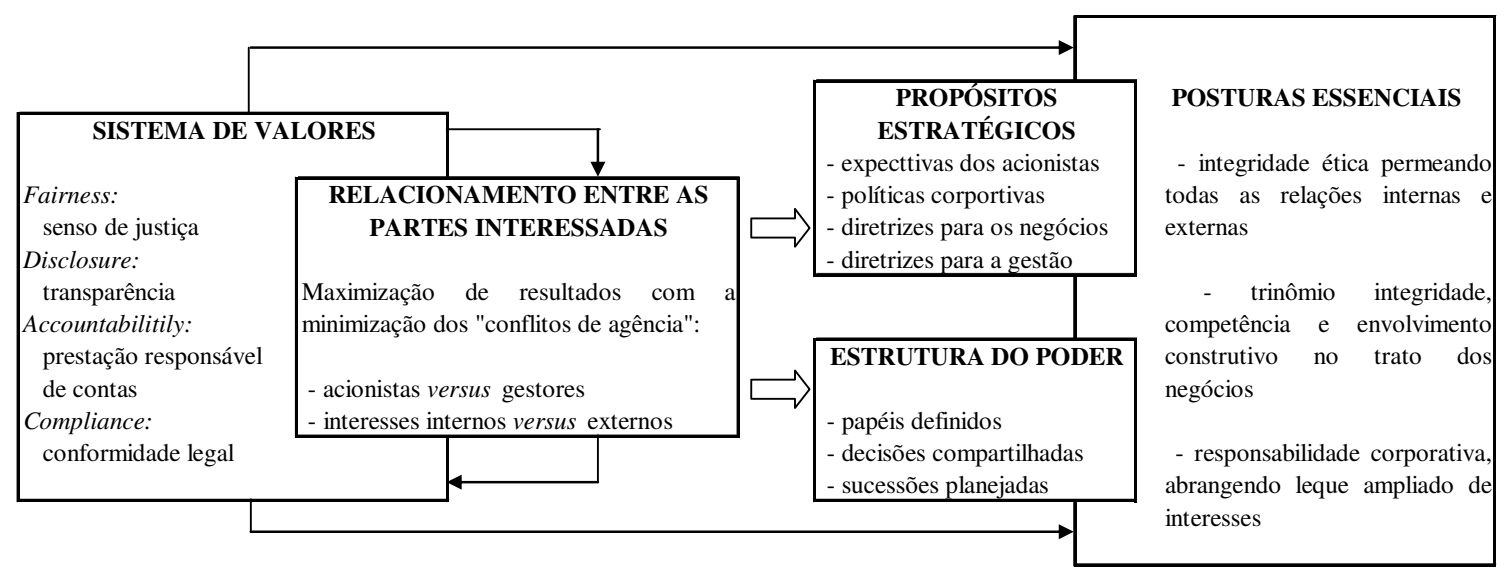

Figura 1 - Conjunto de definições de Governança Corporativa

FONTE: adaptado ANDRADE e ROSSETTI; 2004, p. 28.

\subsection{A governança corporativa no mundo}

Uma pesquisa realizada pela McKinsey \& Company (2002, p. 2) em cooperação com o Fórum Global de Governança Corporativa aplicou um questionário para saber a opinião geral 
dos investidores, que compreendeu o período de abril e maio de 2002. Esse questionário baseou-se nas respostas de 200 investidores institucionais, responsáveis por investimentos da ordem 2 trilhões de dólares. Os resultados apontam um grande interesse por parte dos investidores institucionais em relação à qualidade da divulgação da informação contábil com superior prioridade.

A pesquisa abrangeu 31 países na Ásia, Europa, América Latina, Oriente Médio, África e América do Norte. A origem dos investidores é: 32\% da Europa Ocidental, 21\% da América do Norte, $20 \%$ da América Latina, $18 \%$ da Ásia e 9\% da Europa Oriental e África. Os tipos de investidores são: $20 \%$ fundos mútuos, $17 \%$ investidores particulares (private equity), 11\% money manager, $10 \%$ capital de risco, $9 \%$ fundos de pensão, $9 \%$ corretor de valores, $8 \%$ insurance (seguradora), 7\% bancos e 9\% outros (MCKINSEY \& COMPANY, 2002, p.1).

Os investidores consideram a Governança Corporativa em igual patamar com os indicadores financeiros para avaliar as decisões de investimentos. A maioria dos investidores estão dispostos a pagar um prêmio pelas empresas que apresentam padrões elevados de Governança Corporativa. Esses prêmios variam de 12 a 14\% para países que estão na América do Norte e Oeste Europeu, de 20 a 25\% para países que estão na Ásia e na América Latina e 30\% para países que estão na Europa Ocidental e África (MCKINSEY \& COMPANY, ibid., p. 2).

Segundo a pesquisa de McKinsey \& Company (ibid., p. 2), a transparência financeira é de interesse primordial. $\mathrm{Na}$ busca pela melhor transparência da contabilidade, os investidores expressam o interesse na unificação dos padrões globais de contabilidade, com $90 \%$ sendo favorável a tal movimento.

A governança permanece importante se comparada com indicadores financeiros, particularmente nos mercados emergentes. Dos Investidores da África e da Europa Oriental $15 \%$ consideram a Governança Corporativa menos importante que os indicadores financeiros, $45 \%$ a consideram tão importante quanto e $40 \%$ consideram mais importante.

Na América Latina, 16\% consideram a Governança Corporativa menos importante que os indicadores financeiros, $66 \%$ a consideram tão importante quanto e $18 \%$ a consideram mais importante. Já na Ásia os resultados foram parecidos aos encontrados na América Latina, 
sendo que $18 \%$ consideram a Governança Corporativa menos importante que os indicadores financeiros, $61 \%$ a consideram tão importante quanto e $21 \%$ consideram mais importante.

Na América do Norte e na Europa Ocidental os resultados também são próximos. Na América do Norte, $43 \%$ consideram a Governança Corporativa menos importante que os indicadores financeiros, $50 \%$ a consideram tão importante quanto e $7 \%$ consideram mais importante. $\mathrm{Na}$ Europa Ocidental, 44\% consideram a Governança Corporativa menos importante que os indicadores financeiros, $41 \%$ a consideram tão importante quanto e $15 \%$ consideram mais importante (MCKINSEY \& COMPANY, 2002, p. 3).

$\mathrm{Na}$ questão sobre como a Governança Corporativa afeta as decisões de investimentos os entrevistados responderam que $63 \%$ evitam certas empresas que não adotam Governança Corporativa, $57 \%$ evitam certas empresas que tiveram aumentos ou reduções nas suas ações, $31 \%$ evitam certos países que não possuem que não têm ou não adotam código de melhores práticas de Governança Corporativa e $28 \%$ evitam certos países cujas ações tiveram aumentos ou diminuições. As questões eram de múltipla escolha e podia ter mais de uma resposta.

A pesquisa mostrou também que uma maioria significativa dos investidores disse que estão dispostos a pagar um prêmio para empresas com melhor Governança. No Oeste Europeu e na Ásia, 78\% dos investidores estão dispostos a pagar um prêmio pela melhor Governança e 22\% dos investidores não. Na América do Norte e América Latina, 76\% dos investidores estão dispostos a pagar um prêmio pela melhor Governança e $24 \%$ dos investidores não. Já na África e Leste Europeu, 73\% dos investidores estão dispostos a pagar um prêmio pela melhor Governança e $27 \%$ dos investidores não.

Ainda de acordo com McKinsey \& Company (ibid., p. 7), os investidores apóiam a unificação global dos padrões de contabilidade, mas discordam que o atual padrão deveria prevalecer. A pergunta foi se o nível dos padrões globais de contabilidade é desejável, $90 \%$ dos entrevistados responderam sim, $5 \%$ responderam não e $5 \%$ responderam que não tem certeza.

Outra pergunta sobre o padrão preferido como padrão global, caso isso fosse possível. $\mathrm{Na}$ Europa Ocidental $78 \%$ preferem o IASC-GAAP (normas internacionais de contabilidade Generally Accepted Accounting Principles - promulgadas pelo International Accounting Standards Committee) e $2 \%$ o US-GAAP (normas de contabilidade utilizadas nos Estados 
Unidos da América, conhecidas como United States Generally Accepted Accounting Principles), ficando próximo dos resultados obtidos na Europa Oriental e África, onde 76\% preferem o IASC-GAAP e $24 \%$ o US-GAAP.

Na Ásia, a preferência foi de $65 \%$ para o IASC-GAAP e 35\% para o US-GAAP. Na América Latina, $41 \%$ preferem o IASC-GAAP e 59\% o US-GAAP. Já na América do Norte, 24\% preferem o IASC-GAAP e $76 \%$ o US-GAAP. O quadro 1 resume os principais aspectos abordados nessa pesquisa e a opinião dos investidores institucionais.

Quadro 1 - Posição de investidores em relação à práticas de governança corporativa

\begin{tabular}{|l|c|c|c|c|c|}
\hline Aspectos Pesquisados Ásia & $\begin{array}{c}\text { Europa } \\
\text { Ocidental }\end{array}$ & $\begin{array}{c}\text { América } \\
\text { Latina }\end{array}$ & $\begin{array}{c}\text { Europa } \\
\text { Oriental e } \\
\text { África }\end{array}$ & $\begin{array}{c}\text { América } \\
\text { do Norte }\end{array}$ \\
\hline Origem dos investidores & $18 \%$ & $32 \%$ & $20 \%$ & $9 \%$ & $21 \%$ \\
\hline Prêmio pela governança & 20 a $25 \%$ & $30 \%$ & 20 a $25 \%$ & $\begin{array}{c}12 \text { a } 14 \% \\
\text { Europa e } 30 \% \\
\text { África }\end{array}$ & 12 a $14 \%$ \\
\hline $\begin{array}{l}\text { Investidores que consideram a GC } \\
\text { menos importante que indicadores } \\
\text { financeiros }\end{array}$ & $18 \%$ & $44 \%$ & $16 \%$ & $15 \%$ & $43 \%$ \\
\hline $\begin{array}{l}\text { Investidores que consideram a GC tão } \\
\text { importante quanto indicadores } \\
\text { financeiros }\end{array}$ & $61 \%$ & $41 \%$ & $66 \%$ & $45 \%$ & $50 \%$ \\
\hline $\begin{array}{l}\text { Investidores que consideram a GC } \\
\text { mais importante que indicadores } \\
\text { financeiros }\end{array}$ & $21 \%$ & $15 \%$ & $18 \%$ & $40 \%$ & $7 \%$ \\
\hline $\begin{array}{l}\text { Investidores dispostos a pagar um } \\
\text { prêmio por melhores práticas de GC }\end{array}$ & $78 \%$ & $78 \%$ & $76 \%$ & $73 \%$ & $76 \%$ \\
\hline $\begin{array}{l}\text { Investidores que preferem o IASC- } \\
\text { GAAP }\end{array}$ & $65 \%$ & $78 \%$ & $41 \%$ & $76 \%$ & $24 \%$ \\
\hline Investidores que preferem o US-GAAP & $35 \%$ & $2 \%$ & $59 \%$ & $24 \%$ & $76 \%$ \\
\hline
\end{tabular}

FONTE: elaborado a partir da pesquisa McKinsey \& Company (2002)

Quase todos os investidores apóiam a remuneração por meio da opção de ações. A pergunta foi se os investidores são a favor da remuneração dos gerentes e diretores por meio da opção de ações, incluindo os ganhos e perdas. São a favor $83 \%$ dos entrevistados, são contra $9 \%$ e $8 \%$ não tem certeza.

A pesquisa da McKinsey \& Company (2002, p. 9) mostrou que os investidores identificam as publicações transparentes com alto nível de impacto nas suas decisões de investimento. Os fatores corporativos são transparência contábil com $71 \%$ e igualdade aos acionistas com $47 \%$. Os fatores do mercado de capitais são infra-estrutura e regulamentações do mercado com $43 \%$, padrões internacionais de contabilidade com $42 \%$ e liquidez do mercado com $37 \%$. 
Como fatores amplos e cada país foram considerados: direito à propriedade com 46\%, pressão na corrupção com 32\%, regulamentação de falência e insolvência com 32\%, ambiente fiscal com $31 \%$ e o sistema bancário com $30 \%$.

Os investidores identificaram as prioridades da Governança para as empresas. Ampla transparência e informações na hora certa correspondem a 52\% das respostas dos entrevistados. Mais independência dos Conselhos de Administração com 44\%, maior prática efetiva dos diretores com $38 \%$ e adotar a atuação do diretor/administrador como recompensa com 28\% (MCKINSEY \& COMPANY, 2002, p. 10).

McKinsey \& Company (ibid., p. 11) verificaram que os investidores identificam as prioridades da Governança para policymaker (política dos fabricantes). As reformas prioritárias foram: fortalecer os direitos dos acionistas com 33\%, aprimorar os padrões contábeis com $32 \%$, mais transparência efetiva com $31 \%$ e forte coerção (enforcement).

Essa pesquisa conduzida pela McKinsey \& Company mostra que boas práticas de governança corporativa tem atraído cada vez mais a atenção por parte dos investidores e sido fator a ser perseguido pela gestão das companhias. No tocante ao tema desta dissertação, é importante ressaltar que o fator corporativo de maior importância para os investidores é transparência contábil. Mais de $70 \%$ dos investidores apontam a publicação de demonstrações transparentes como tendo alto impacto nas suas decisões de investimento.

Por isso, as empresas devem estar atentas no sentido de buscar reduzir a assimetria de informação - e isso pode ser efetuado por meio da emissão de relatórios contábil-financeiros com alto grau de evidenciação - como forma de buscar a redução do seu custo de captação de recursos financeiros por parte dos investidores. Os resultados da pesquisa da McKinsey \& Company apontam que os investidores estão atentos a esse aspecto e, assim, cabe às organizações a adoção de normas contábeis mais transparentes. 


\subsection{A governança corporativa no Brasil}

No Brasil, o Instituto Brasileiro de Governança Corporativa (IBGC) é um órgão criado com a meta principal de contribuir para otimizar o conceito de Governança Corporativa nas empresas nacionais. Ao abraçar essa missão, o Instituto visa cooperar com o aprimoramento do padrão de governo das empresas nacionais, para seu sucesso e perpetuação. A boa Governança Corporativa assegura aos sócios eqüidade, transparência, prestação de contas (accountability) e responsabilidade pelos resultados. Dentre suas iniciativas e esforços neste campo destacam-se a elaboração e revisão do Código Brasileiro das Melhores Práticas de governança corporativa.

O Instituto é considerado nacional e internacionalmente como um dos principais responsáveis pela introdução do conceito de governança corporativa no país, pelo reconhecimento e disseminação da importância das boas práticas e pelo crescente interesse das empresas brasileiras em se fortalecer por meio da adoção das mesmas.

A pesquisa mais recente sobre Governança Corporativa no Brasil intitulada Panorama da Governança Corporativa no Brasil, foi conduzida em 2001 em parceria pela McKinsey \& Company e Korn Ferry International, onde são enfocadas características da estrutura de propriedade e liderança das empresas nacionais e a organização e as práticas dos conselhos de administração. A pesquisa diz de as empresas nacionais, premidas por necessidades de financiamento e pelos desafios impostos pela competição em nível global, estão reformulando suas práticas de governança corporativa.

A pesquisa da McKinsey e Korn/Ferry demonstra que começa a existir entre acionistas, controladores e administradores de empresas uma conscientização da importância da governança corporativa como forma de valorizar a companhia. Nota-se uma preocupação com a separação entre funções executivas (diretores) e as atribuições de formular a política da companhia (conselho de administração), bem como com a transparência das informações. Esse trabalho contribuiu para demonstrar que a nova lei de sociedades anônimas e iniciativas como o Novo Mercado da BOVESPA servirão para estimular e impulsionar as companhias que tenham aspiração de competitividade e crescimento a implantar a governança corporativa. 
$\mathrm{O}$ enfoque da pesquisa foram os conselheiros das empresas brasileiras com faturamento superior a US\$ 250 milhões. Do total de conselheiros contatados, 127, representando 74 empresas, responderam à pesquisa, além de terem sido entrevistados 14 conselheiros. Essa pesquisa revelou como é o modelo atual de governança corporativa nas empresas, os novos modelos que estão surgindo em função das mudanças no ambiente competitivo e nas próprias empresas e qual será o modelo que provavelmente irá prevalecer no Brasil (MCKINSEY e KORN/FERRY, 2001, p. 6).

McKinsey e Korn/Ferry (ibid., p. 6) perguntaram como é o modelo atual de governança corporativa utilizado pelas organizações. As empresas com forte liderança e capacidades financeiras e que conseguiram ser bem-sucedidas no Brasil determinaram o modelo atual de governança corporativa. Esse modelo caracteriza se por uma forte concentração da propriedade em apenas alguns acionistas majoritários.

Essa estrutura de propriedade resulta numa sobreposição entre propriedade e liderança executiva, na qual os membros do conselho representam o interesse dos acionistas controladores ou majoritários, e os acionistas minoritários são pouco ativos. Além disso, as estruturas e os procedimentos de governança são geralmente informais.

Prova disso é que $44 \%$ dos membros de conselhos responderam que não existem sub-comitês constituídos em suas empresas e somente $11 \%$ estão satisfeitos com os processos atuais. Com relação à questão da transparência na comunicação, a maioria dos membros do conselho considera que o nível atual de comunicação com os mercados financeiros é satisfatório, já que não há interesse em divulgar informações sigilosas aos concorrentes. Os acionistas minoritários, por sua vez, consideraram que o processo de comunicação era insuficiente.

A pesquisa indicou ainda que apenas $27 \%$ dos respondentes indicaram estar satisfeitos com a coerência das decisões estratégicas tomadas em suas empresas, e quase a metade dos conselheiros acredita que uma mudança no atual modelo poderia criar valor. Nas empresas familiares, isso ficou ainda mais evidente, pois $62 \%$ responderam que é necessária uma mudança na estratégia empresarial adotada pela organização.

Com relação ao grau de satisfação geral em relação a Governança Corporativa, $54 \%$ dos conselheiros acham que o modelo necessita ou poderia melhorar e $46 \%$ acham o modelo 
satisfatório. Nesse aspecto, a pesquisa identificou que está ocorrendo uma mudança rumo a um modelo emergente de governança caracterizado por um maior profissionalismo. Nesse modelo, as estruturas do conselho e seus processos são bem definidos, e os conselheiros têm melhor qualificação para lidar com questões estratégicas. Além disso, os acionistas minoritários estão se tornando mais ativos.

A estrutura de propriedade, no entanto, permanece com uma alta concentração da propriedade, e a sobreposição entre propriedade e liderança executiva continua sendo observada. Esse crescente profissionalismo, embora encontre alguma resistência por parte de alguns conselheiros controladores, vem contribuindo para reforçar a postura estratégica do conselho, tornar os processos decisórios mais eficientes, estabelecer um melhor relacionamento com os mercados de capitais e os órgãos de regulamentação.

Ainda de acordo com a Mckinsey e Korn/Ferry (2001, p. 7), as empresas que almejam atingir um alto índice de crescimento e competir globalmente além de sua capacidade de financiamento evoluirão para o modelo de mercado. Nesse modelo, acionistas majoritários cedem parte do controle, tendo acesso, assim, a novas fontes de capital, capacitando-se para atrair novos talentos, ou proporcionando uma base para a entrada em novos mercados ou áreas de negócio. Em resumo, as empresas no Brasil estão reformulando suas práticas de governança corporativa para enfrentar os desafios impostos pela nova realidade econômica brasileira. Mas, ainda é cedo para avaliar se tais mudanças serão suficientes para essas empresas competirem globalmente, ou se talvez seja necessário aprofundar as reformas no sentido de um maior compartilhamento da propriedade e do controle.

A pesquisa de McKinsey e Korn/Ferry faz um diagnóstico da Governança Corporativa no Brasil. O modelo atual pode caracterizado em cinco dimensões: estrutura de propriedade, relação entre propriedade e gestão executiva, estrutura do conselho, pessoas e processos do conselho. Será focado neste estudo, dentro dos processos do conselho, o nível de transparência adequado segundo as empresas, mas insuficiente segundo os investidores.

Uma característica primordial do atual modelo brasileiro de governança corporativa é o nível de transparência e comunicação com o mercado financeiro e os acionistas minoritários. A maioria dos conselheiros (76\%) acredita que a comunicação com o mercado é satisfatória, já que um nível excessivo de comunicação resultaria na disseminação de informação valiosa 
para os concorrentes em um mercado ainda muito informal. Por sua vez, os acionistas minoritários não estão satisfeitos com o atual nível de transparência.

As entrevistas mostraram diversas situações nas quais a pouca transparência é um impedimento para a realização de novos investimentos por parte de acionistas minoritários como, por exemplo, os fundos de pensão. A comunicação com o mercado financeiro e com os acionistas minoritários é adequada para $76 \%$ dos respondentes, é insuficiente para $22 \%$ e excessiva para $2 \%$ de acordo com McKinsey e Korn/Ferry.

Os benefícios esperados da mudança de modelo com a profissionalização das práticas de governança devem contribuir para uma maior eficiência na tomada de decisões, em um contexto competitivo mais complexo, melhor relacionamento com o mercado de capitais e maior consideração dos interesses dos acionistas minoritários. Como conseqüência, as empresas devem ter um melhor desempenho devido a melhores estratégias e, potencialmente, menor custo de capital, além de maior atratividade para os investidores (MCKINSEY e KORN/FERRY, 2001, p. 28).

\subsection{A BOVESPA e os níveis diferenciados de governança corporativa}

Segundo Andrade e Rossetti (2005, p. 1), uma das mais consistentes tendências que se observa no mundo corporativo, no primeiro quadriênio do século 21, é a crescente pressão do mercado pela adesão das empresas às boas práticas da governança. Como a pressão não nasce dentro das corporações, mas vem de fora, o processo de adesão tem sido lento. Mas é irrecusável e deve acelerar-se daqui para frente.

$\mathrm{Na}$ maior parte dos países, a adesão às melhores práticas de governança corporativa tem avançado. É o que se observa no Brasil, em resposta a um conjunto consistente de novas condições que vêm se estabelecendo nos últimos anos. O balanço do qüinqüênio 2000-2004 é positivo. Foram modestos os avanços da nova Lei das S/A, mas, em contrapartida, outras forças externas passaram a atuar com maior vigor. 
A BOVESPA criou o Novo Mercado e os níveis diferenciados de governança, abrindo-os à adesão voluntária. A Comissão de Valores Mobiliários (CVM) editou cartilha recomendando padrões de conduta superiores aos exigidos pelos institutos legais e pelos marcos regulatórios. Os maiores fundos de pensão editaram códigos de boa governança e passaram a privilegiar participações em empresas que adotassem os princípios sugeridos. O IBGC editou edições revistas de seu código (ANDRADE e ROSSETTI, 2005, p. 2).

Implantados em dezembro de 2000 pela BOVESPA, os Níveis Diferenciados de Governança Corporativa são segmentos especiais de listagem que foram desenvolvidos com o objetivo de proporcionar um ambiente de negociação que estimulasse, simultaneamente, o interesse dos investidores e a valorização das companhias.

Empresas listadas nesses segmentos oferecem aos seus acionistas investidores melhorias nas práticas de governança corporativa que ampliam os direitos societários dos acionistas minoritários e aumentam a transparência das companhias, com divulgação de maior volume de informações e de melhor qualidade, facilitando o acompanhamento de sua performance.

A premissa básica é que a adoção de boas práticas de governança corporativa pelas companhias confere maior credibilidade ao mercado acionário e, como conseqüência, aumenta a confiança e a disposição dos investidores em adquirirem as suas ações, pagarem um preço melhor por elas, reduzindo seu custo de captação.

A adesão das Companhias ao Nível 1 ou ao Nível 2 depende do grau de compromisso assumido e é formalizada por meio de um contrato, assinado pela BOVESPA, pela Companhia, seus administradores, conselheiros fiscais e controladores. Ao assinarem o contrato, as partes acordam em observar o Regulamento de Listagem do segmento específico, que consolida os requisitos que devem ser atendidos pelas Companhias listadas naquele segmento, além de, no caso das Companhias Nível 2, adotar a arbitragem para solução de eventuais conflitos societários.

Para uma empresa aderir ao Nível 1 de "Práticas Diferenciadas de Governança Corporativa" ela tem que atender algumas exigências, como manter em circulação ações que representam pelo menos $25 \%$ do seu capital, realizar ofertas públicas de ações através de mecanismos que favoreçam a dispersão do capital, divulgar acordos de acionistas e programas de stock options 
entre outros. Já para adesão ao Nível 2, além dos requisitos contidos no Nível 1, e empresa tem que atender a exigências mais amplas, como disponibilizar as demonstrações contábeis segundo normas internacionais, estender a todos os acionistas os mesmos direitos concedidos aos acionistas ordinários, aderir à Câmara de Arbitragem para resolução de conflitos societários entre outros aspectos. Esses aspectos serão analisados com mais detalhes na seqüência.

\subsubsection{Nível 1 de governança corporativa}

As Companhias Nível 1 se comprometem, principalmente, com melhorias na prestação de informações ao mercado e com a dispersão acionária. A companhia aberta listada no Nível 1 tem como obrigações adicionais à legislação:

- Melhoria nas informações prestadas, adicionando às Informações Trimestrais/ITR (documento que é enviado pelas companhias listadas à CVM e à BOVESPA), demonstrações financeiras consolidadas e a demonstração dos fluxos de caixa;

- Melhoria nas informações relativas a cada exercício social, adicionando às Demonstrações Financeiras Padronizadas/DFP (documento que é enviado pelas companhias listadas à CVM e à BOVESPA), demonstrações financeiras anuais, tais como a demonstração dos fluxos de caixa;

- Melhoria nas informações prestadas, adicionando às Informações Anuais/IAN (documento que é enviado pelas companhias listadas à CVM e à BOVESPA), informações como a quantidade e características dos valores mobiliários de emissão da companhia detidos pelos grupos de acionistas controladores, membros do Conselho de Administração, diretores e membros do Conselho Fiscal, bem como a evolução dessas posições;

- Realização de reuniões públicas com analistas e investidores, ao menos uma vez por ano;

- Apresentação de um calendário anual, do qual conste a programação dos eventos corporativos, tais como assembléias, divulgação de resultados e outros;

- Divulgação dos termos dos contratos firmados entre a companhia e partes relacionadas; 
- Divulgação, em bases mensais, das negociações de valores mobiliários e derivativos de emissão da companhia por parte dos acionistas controladores;

- Manutenção em circulação de uma parcela mínima de ações, representando $25 \%$ (vinte e cinco por cento) do capital social da companhia;

- Adoção de mecanismos que favoreçam a dispersão do capital, quando da realização de distribuições públicas de ações.

Ao implantar esses níveis diferenciados, a Bolsa de Valores de São Paulo contribui para o desenvolvimento de um ambiente de negócios que estimula o desenvolvimento de práticas de boa governança corporativa por parte das empresas brasileiras. Isso desperta também a atenção dos investidores, que passam a ter condições de melhor analisarem as diversas opções de alocação de recursos monetários. Em abril de 2006, 35 empresas já haviam aderido ao Nível 1 de Governança Corporativa da BOVESPA.

\subsubsection{Nível 2 de governança corporativa}

As Companhias Nível 2 se comprometem a cumprir as regras aplicáveis ao Nível 1 e, adicionalmente, um conjunto mais amplo de práticas de governança relativas aos direitos societários dos acionistas minoritários. Por exemplo, a companhia aberta listada no Nível 2 tem como obrigações adicionais à legislação:

- Divulgação de demonstrações financeiras de acordo com padrões internacionais USGAAP ou IASC-GAAP;

- Conselho de Administração com mínimo de 5 (cinco) membros e mandato unificado de até 2 (dois) anos, permitida a reeleição. No mínimo, 20\% (vinte por cento) dos membros deverão ser conselheiros independentes;

- Direito de voto às ações preferenciais em algumas matérias, tais como, transformação, incorporação, fusão ou cisão da companhia e aprovação de contratos entre a companhia e empresas do mesmo grupo sempre que, por força de disposição legal ou estatutária, sejam deliberados em assembléia geral;

- Extensão para todos os acionistas detentores de ações ordinárias das mesmas condições obtidas pelos controladores quando da venda do controle da companhia e de, no 
mínimo, $80 \%$ (oitenta por cento) deste valor para os detentores de ações preferenciais (tag along);

- Realização de uma oferta pública de aquisição de todas as ações em circulação, no mínimo, pelo valor econômico, nas hipóteses de fechamento do capital ou cancelamento do registro de negociação neste Nível;

- Adesão à Câmara de Arbitragem do Mercado para resolução de conflitos societários.

Além de presentes no Regulamento de Listagem, alguns desses compromissos deverão ser aprovados em Assembléias Gerais e incluídos no Estatuto Social da companhia. O atendimento dessas normas por parte das empresas permite aos investidores, entre outros aspectos, uma diminuição do risco de uma avaliação errada das suas opções de investimento. Além disso, a regulamentação das normas de governança corporativa oferece maior proteção ao direito desses acionistas, e torna o mercado acionário mais seguro e confiável.

Em abril de 2006, a BOVESPA já contava com 13 empresas listadas no Nível 2 de Governança Corporativa. Isso mostra que as organizações têm trabalhado no sentido de promover sua migração para os níveis diferenciados e, como a adesão é voluntária, fica claro que as empresas esperam obter algum retorno com isso, seja na melhoria da imagem institucional, seja na maior demanda por suas ações ou na diminuição do custo de captação, que será analisado neste trabalho.

\subsubsection{Novo Mercado}

O Novo Mercado é um segmento de listagem destinado à negociação de ações emitidas por companhias que se comprometam, voluntariamente, com a adoção de práticas de Governança Corporativa adicionais em relação ao que é exigido pela legislação.

A valorização e a liquidez das ações são influenciadas positivamente pelo grau de segurança oferecido pelos direitos concedidos aos acionistas e pela qualidade das informações prestadas pelas companhias. Essa é a premissa básica do Novo Mercado. 
Para Peixe (2003, p. 42), as vantagens para as empresas participarem do Novo Mercado é que deverão conseguir melhor precificação de suas ações, conseguindo com isso menores custos de captação, baseado no pressuposto de que os investidores dispõem-se a pagar um prêmio para as empresas que adotam melhores práticas de Governança Corporativa e que apresentam maior grau de transparência. Já para o investidor, a vantagem é a maior segurança e a oportunidade de comprar o que a BOVESPA chama 'produto ação diferenciado', pois são negociadas apenas ações com direito a voto (ordinárias), que permitem ao investidor participar e acompanhar de perto a evolução da companhia.

A entrada de uma companhia no Novo Mercado ocorre por meio da assinatura de um contrato e implica a adesão a um conjunto de regras societárias, genericamente chamadas de "boas práticas de governança corporativa", mais exigentes do que as presentes na legislação brasileira. Essas regras, consolidadas no Regulamento de Listagem do Novo Mercado, ampliam os direitos dos acionistas, melhoram a qualidade das informações usualmente prestadas pelas companhias, bem como a dispersão acionária e, ao determinar a resolução dos conflitos societários por meio de uma Câmara de Arbitragem, oferecem aos investidores a segurança de uma alternativa mais ágil e especializada.

A principal inovação do Novo Mercado, em relação à legislação, é a exigência de que o capital social da companhia seja composto somente por ações ordinárias. Porém, esta não é a única. Por exemplo, a companhia aberta participante do Novo Mercado tem como obrigações adicionais:

- Extensão para todos os acionistas das mesmas condições obtidas pelos controladores quando da venda do controle da companhia (tag along);

- Realização de uma oferta pública de aquisição de todas as ações em circulação, no mínimo, pelo valor econômico, nas hipóteses de fechamento do capital ou cancelamento do registro de negociação no Novo Mercado;

- Conselho de Administração com mínimo de 5 (cinco) membros e mandato unificado de até 2 (dois) anos, permitida a reeleição. No mínimo, 20\% (vinte por cento) dos membros deverão ser conselheiros independentes;

- Melhoria nas informações prestadas, adicionando às Informações Trimestrais (ITR) documento que é enviado pelas companhias listadas à CVM e à BOVESPA, 
disponibilizado ao público e que contém demonstrações financeiras trimestrais - entre outras: demonstrações financeiras consolidadas e a demonstração dos fluxos de caixa;

- Melhoria nas informações relativas a cada exercício social, adicionando às Demonstrações Financeiras Padronizadas (DFP) - documento que é enviado pelas companhias listadas à CVM e à BOVESPA, disponibilizado ao público e que contém demonstrações financeiras anuais - entre outras, a demonstração dos fluxos de caixa;

- Divulgação de demonstrações financeiras de acordo com padrões internacionais;

- Melhoria nas informações prestadas, adicionando às Informações Anuais (IAN) documento que é enviado pelas companhias listadas à CVM e à BOVESPA, disponibilizado ao público e que contém informações corporativas - entre outras: a quantidade e características dos valores mobiliários de emissão da companhia detidos pelos grupos de acionistas controladores, membros do Conselho de Administração, diretores e membros do Conselho Fiscal, bem como a evolução dessas posições;

- Realização de reuniões públicas com analistas e investidores, ao menos uma vez por ano;

- Apresentação de um calendário anual, do qual conste a programação dos eventos corporativos, tais como assembléias, divulgação de resultados etc.;

- Divulgação dos termos dos contratos firmados entre a companhia e partes relacionadas;

- Divulgação, em bases mensais, das negociações de valores mobiliários e derivativos de emissão da companhia por parte dos acionistas controladores;

- Manutenção em circulação de uma parcela mínima de ações, representando 25\% (vinte e cinco por cento) do capital social da companhia;

- Quando da realização de distribuições públicas de ações, adoção de mecanismos que favoreçam a dispersão do capital;

- Adesão à Câmara de Arbitragem do Mercado para resolução de conflitos societários.

Além de presentes no Regulamento de Listagem, alguns desses compromissos deverão ser aprovados em Assembléias Gerais e incluídos no Estatuto Social da companhia. Em abril de 2006 haviam 24 empresas listadas no Novo Mercado.

Por parte dos investidores, a adesão de empresas no novo mercado permitirão uma maior precisão no processo de precificação das suas opções de investimento, melhora no processo de acompanhamento e fiscalização das companhias e maior respeito dos seus direitos 
societários. Uma vez que o grau de observância dos princípios de boa governança corporativa estão sendo levados em consideração pelos investidores, as empresas serão cada vez mais estimuladas a aderirem aos níveis diferenciados da BOVESPA. Isso poderá conduzir ao fortalecimento das companhias e a dinamização do mercado acionário.

\subsection{Relação entre governança corporativa e transparência}

O Código das Melhores Práticas de Governança Corporativa do IBGC destaca que um dos princípios básicos que inspiraram a criação do mesmo foi a transparência. De acordo com o código, mais do que a obrigação de informar, a Administração deve cultivar o desejo de informar, sabendo que da boa comunicação interna e externa, particularmente quando espontânea, franca e rápida, resulta um clima de confiança, tanto internamente, quanto nas relações da empresa com terceiros. Além disso, a comunicação não deve restringir-se ao desempenho econômico-financeiro, mas deve contemplar também os demais fatores (inclusive intangíveis) que norteiam a ação empresarial e que conduzem à criação de valor.

Adicionalmente, o Código destaca que uma boa governança corporativa também envolve prestar informações que sejam pertinentes, além das que são obrigatórios por lei ou regulamento, tão logo estejam disponíveis, e a todos os interessados, ressaltando que toda informação que possa influenciar decisões de investimento deve ser divulgada imediata e simultaneamente a todos os interessados.

Sob a ótica da teoria de agência, Jensen e Meckling (1976, p. 46) mostram que tanto os custos de monitoramento externos como os custos de monitoramento internos recaem sobre o gerente-proprietário e, por isso, é do seu maior interesse garantir que o monitoramento seja feito ao custo mínimo.

Os autores destacam que a transparência dos relatórios financeiros por parte das empresas é um mecanismo de monitoramento da gerência por parte dos acionistas externos e credores. Ressaltam que, dado que as informações financeiras são obtidas por um custo mais baixo pelos gerentes da companhia do que pelos acionistas (já que o gestor necessita das informações internamente para a tomada de decisão), a transparência seria uma forma de 
buscar minimizar o conflito de agência (seria considerado como um custo de certificação, que faz parte dos custos de agência).

Bushman e Smith (2003, p. 71) destacam o importante papel da governança da informação contábil, uma vez que a mesma serve como um instrumento fundamental de monitoramento dos gestores da empresa pelos investidores externos.

\subsection{A questão da transparência}

A transparência é um dos quatro princípios fundamentais que são sustentação à boa Governança Corporativa. De acordo com Iudícibus (2000, p. 28), o objetivo principal da Contabilidade (e dos relatórios dela emanados) é fornecer informação econômica relevante para que cada usuário possa tomar suas decisões e realizar seus julgamentos com segurança.

O que Iudícibus ressalta é a importância da evidenciação das informações contábeis, pois, por meio da divulgação, a contabilidade consegue atingir seu objetivo principal. Dessa forma, todos os eventos que afetam, ou que possam vir a afetar, a situação econômica, financeira e patrimonial de uma entidade, devem ser evidenciados. Na verdade, para o autor, o disclosure está ligado aos objetivos da Contabilidade, ao garantir informações diferenciadas para vários tipos de usuários.

Para o International Accounting Standards Board (IASB), o objetivo das demonstrações contábeis é fornecer informações sobre a posição financeira, os resultados e as mudanças na posição financeira de uma entidade, que sejam úteis a um grande número de usuários em suas tomadas de decisão.

Há uma discussão no sentido de verificar se a empresa tem ou não benefícios em função de uma melhor evidenciação. Existe um consenso entre profissionais e acadêmicos, de que uma melhor divulgação pode trazer benefício para a empresa.

Para corroborar com esse consenso, a PricewaterhouseCoopers realizou uma pesquisa de opinião com investidores institucionais e analistas para levantar quais são os benefícios de uma melhor evidenciação. Os resultados dessa pesquisa foram publicados em 2001. De 
acordo com Eccles et al. (2001), foram citados cinco pontos como sendo os maiores benefícios de uma melhor evidenciação, são eles:

- $\quad$ Aumento da credibilidade dos gestores;

- Mais investidores de longo prazo;

- Maior monitoramento por parte dos analistas;

- Melhor acesso a novos capitais;

- Melhor avaliação do preço das ações.

No que se refere ao aumento de credibilidade dos gestores, verificou-se que, fornecendo coerentemente informações em momentos bons e ruins, a gerência reafirma sua credibilidade no mercado. Outro aspecto levantado foi de que o mercado não gosta de surpresas, principalmente as negativas. De acordo com Eccles et al. (2001, p. 193), isso não significa que uma má notícia não terá um efeito negativo no preço das ações da empresa. Provavelmente terá, e provavelmente deveria ter se a notícia é suficientemente ruim, e os indicadores principais também são negativos. Mas, quando esses indicadores tornarem-se positivos, o preço das ações da companhia também terá maior probabilidade de ascensão.

Quanto ao aumento de investidores de longo prazo, Eccles et al. (ibid., p. 194), complementam que por existirem investidores que decidem aumentar os seus investimentos e também o surgimento de novos investimentos de longo prazo, ambos necessitam de informações que trarão a eles um maior conforto em realizar esses compromissos de longo prazo.

O melhor acesso a novos capitais, relaciona melhor evidenciação com redução do custo de capital. Assim sendo, a empresa que melhor divulga tem um maior acesso a novos capitais e conseqüentemente, mais oportunidades de obter um menor custo de capital. Porém, para Botosan (1997, p. 323), a associação entre o nível de evidenciação e o custo de capital próprio não está bem estabelecida e tem sido difícil de quantificar.

Para Eccles et al. (op. cit., p. 198), a melhor avaliação do preço das ações está relacionada com os demais benefícios, sendo que os quatro primeiros benefícios de uma melhor evidenciação - aumento da credibilidade dos gestores, mais investidores de longo prazo, 
maior monitoramento por parte dos analistas e melhor acesso a novos capitais - logicamente contribuem para aumentar o preço das ações.

Cabe destacar aqui um ponto importante da pesquisa, que mostrou que mais evidenciação não significa melhor evidenciação. Os autores ressaltam que um argumento para a melhoria da evidenciação é que os gestores tipicamente pensam estar fazendo um trabalho de comunicação com o mercado melhor do que o mercado pensa que eles fazem.

Com isso, os administradores pensam ter uma boa comunicação com o mercado, contudo, não têm. Nesse sentido a pesquisa de Eccles et al. (2001, p. 189) afirma que a maioria dos gestores acredita genuinamente em seu grande esforço para dar ao mercado a informação desejada. Porém, a maioria dos analistas e investidores acredita que os gestores poderiam se esforçar mais.

No entanto, os autores destacam o fato de que ler 'melhor evidenciação' como simplesmente 'mais evidenciação', significa dar ao mercado mais da informação que ele considera importante e menos da que ele não considera. É bom ter em mente, contudo, que um mero aumento de quantidade não necessariamente aumentará a qualidade da informação.

De acordo com Bushman et al. (2004, p. 207), transparência pode ser definida como a abrangente disponibilidade de informação relevante e confiável sobre o desempenho periódico, situação financeira, oportunidades de investimento, governança, valor e risco das empresas de capital aberto.

A abertura de informações, ou transparência, é um fator critico para o funcionamento eficiente do mercado de capital. As fontes de divulgação das informações das empresas são através de relatórios financeiros, considerando aqui as demonstrações financeiras junto com a avaliação dos administradores, que são de caráter obrigatório para as empresas que querem operar no mercado de capitais.

Porém, atualmente, muitas empresas têm divulgado informações de caráter voluntário, como Balanço Social que evidência as ações da empresa com relação aos seus funcionários e à sociedade na qual ela está inserida, relatórios com estimativas de resultados futuros, divulgação de suas ações através da internet, através de comunicados oficiais à imprensa. 
Isso mostra que a abertura de informações por parte das empresas tem sem intensificado os últimos anos, dada a globalização do mercado de capitais, a busca por uma harmonização das práticas contábeis, além dos escândalos de fraudes ocorridos recentemente, que ressaltaram quão fragilizada está a governança corporativa nas empresas.

Quando se fala em mercados emergentes, incluindo aqui o Brasil, a abertura voluntária de informações é mais crítica, uma vez que as características marcantes das empresas que estão nesses mercados são alta concentração acionária, administração predominantemente familiar, fortes traços culturais e eventuais instabilidades econômicas. Assim sendo, as empresas divulgam menos e isso causa uma maior insegurança para os investidores nesses países.

Dessa forma, segundo Andrade e Rosseti, (2004 p. 26), verifica-se que em mercados de capitais menos desenvolvidos, a busca do adequado fluxo de informações e de sua ampla divulgação para todo o mercado assume fundamental importância, pois a igualdade de condições de acesso às informações, além de ser um dos princípios básicos da Governança Corporativa é condição fundamental para que o público acredite no mercado.

Bushman e Smith (2003, p. 67) apresentaram em seu trabalho, as formas com a informação contábil-financeira afetam o desempenho de uma economia. A primeira delas é que a informação contábil financeira (da própria empresa e de seus concorrentes) é essencial para a avaliação das oportunidades de investimentos em uma economia, tanto para os próprios gestores tomarem decisão sobre um projeto de investimento, como para os investidores alocarem seus recursos de forma mais eficiente entre as diferentes opções disponíveis no mercado. A segunda destaca a governança corporativa como sendo regra para melhorar a informação contábil-financeira, já que a governança corporativa é um mecanismo dos investidores externos monitorarem os gestores da empresa.

Bushman e Smith (ibid., p. 68) apontam que uma terceira forma de como a informação contábil-financeira afeta o desempenho de uma economia é por meio da redução da assimetria de informações entre os investidores. Uma empresa comprometida em divulgar informações de alta qualidade para todo o mercado reduz o risco de o investidor perder para os investidores mais qualificados, atraindo ainda mais recursos para o mercado de capitais, reduzindo então, o risco de liquidez. 
Num estudo conceitual sobre transparência, Verrecchia (2001, p. 97) destaca que não existe uma teoria unificada sobre o assunto. $\mathrm{O}$ autor ressalta que na literatura a respeito de transparência, não existe um paradigma central, não existe um modelo principal que leve a todas as pesquisas subseqüentes. $\mathrm{O}$ autor interpreta o estágio atual sobre o assunto como caracterizado por uma gama eclética de modelos econômicos altamente idiossincráticos, cada um deles buscando examinar uma pequena peça do quebra-cabeça total da transparência.

Apesar de não existir um modelo principal sobre transparência, ao longo desse trabalho adotase a divisão proposta por Healy e Palepu (2001, p. 406), que separa a teoria sobre transparência em algumas frentes principais, são elas:

- O papel da transparência para o mercado de capitais;

- A regulamentação relacionada à transparência;

- O papel dos auditores e dos usuários intermediários da informação no processo de transparência;

- Os fatores relacionados às decisões dos gerentes sobre transparência;

- As conseqüências para o mercado de capitais, referentes às decisões dos gerentes sobre transparência.

Os temas sobre a regulamentação relacionada à transparência e o papel dos auditores e dos usuários intermediários da informação no processo de transparência não serão abordados nesse trabalho por não estarem diretamente relacionados ao enfoque principal desse trabalho.

O primeiro tema não será considerado, pois esse trabalho considerará a transparência voluntária da empresas e não a obrigatória. Já o segundo tema será descartado, pois o presente trabalho não enfoca a atuação dos auditores, analistas financeiros, entre outros, no processo de transparência das empresas.

A seguir, discutir-se-á o papel da transparência para o mercado de capitais, os fatores relacionados às decisões dos gerentes sobre transparência e as consequiências dessas decisões para o mercado de capitais. 


\subsection{A influência da transparência no custo de capital}

Healy e Palepu (ibid., p. 407) citam que, no contexto do mercado de capitais, um desafio crítico para qualquer economia é a ótima alocação da poupança para as oportunidades de investimento. Existem muitos novos empreendedores e as empresas existentes gostariam de atrair a poupança disponível para financiar suas idéias de negócio.

Os autores ressaltam que existem, pelo menos, dois problemas que surgem nessa busca de atração de capital. Um deles é que os empreendedores tipicamente detêm melhores informações do que os poupadores a respeito das oportunidades de negócio da empresa. Em outras palavras, investidores e poupadores sofrem em problema de assimetria de informação. O outro problema é que, uma vez que os poupadores investiram nas empresas, os empreendedores têm incentivos para desapropriarem a riqueza dos mesmos, criando assim o problema do agenciamento.

Brown et. al (2001), apresentam uma forma pela qual a assimetria informacional pode aumentar o custo de capital de uma empresa. Supondo que a empresa possua alguma informação privilegiada, porém, alguns investidores conseguem ter acesso a essa informação antes que o público em geral. Até que essa informação chegue ao conhecimento do público em geral e esse fato se incorpore no preço da ação, os investidores com acesso privilegiado à essa informação já obtiveram ganhos com a negociação das ações.

Dessa forma, a assimetria informacional propicia um ganho extraordinários para alguns poucos acionistas por um determinado tempo, que é igual à soma das perdas dos outros investidores que desconheciam a informação relevante. Isso faz com que a empresa tenha um custo de capital maior do que realmente deveria ter para cobrir o risco do investimento em seu negócio.

Easley e O'Hara (2004, p. 1553) mostraram, por meio de um modelo baseado em expectativas racionais, que a diferença na composição da informação entre a informação pública e a privada, afeta o custo de capital da companhia, dado que os investidores exigiriam maiores retornos para investirem em ações com menos nível de informação pública. 
De acordo com os autores, este maior retorno é exigido, pois os investidores informados estariam melhores posicionados para alterar o preço da ação na sua carteira a fim de incorporar uma nova informação, fazendo com que os investidores não-informados estejam em desvantagem, aumentando seu risco. Eles sugerem que as companhias podem influenciar o custo de capital afetando a quantidade e a qualidade das informações disponíveis para os investidores.

Para Verrecchia (2001, p. 164), o problema do risco informacional parte do pressuposto de que o mercado seria imperfeito, ou seja, assume-se que as atitudes e comportamentos de cada investidor são suficientes para garantir que haja efeito no preço das ações, nas transações que ocorrerem. Isto implica que todos os investidores tenham que pagar um prêmio para proteger o indivíduo do outro lado da transação contra o problema da seleção adversa inerente na troca de ativos entre agentes com grau de informação diferente. $\mathrm{O}$ autor denomina esse prêmio como o componente da assimetria informacional presente no custo de capital.

Portanto, é de interesse da companhia reduzir a assimetria da informação a fim de buscar a redução do seu custo de capital no momento da emissão, assim, os gestores que esperam fazer uma transação no mercado de capitais possuem incentivos de prover informações voluntariamente a fim de reduzir o problema de assimetria da informação, com o objetivo de reduzir o custo de financiamento externo da empresa, argumenta Verrecchia (ibid., p. 165).

Healy e Palepu (2001, p. 4) apontam duas alternativas como solução para o problema da assimetria de informação. A primeira seria a otimização dos contratos entre o gestor e o investidor, provendo inventivos para que toda informação privada seja transparente, dessa forma, suavizando o problema da diferença de avaliação entre as partes interessadas. Outra potencial solução do problema da assimetria informacional seria uma regulamentação que exigisse que o gestor fizesse de forma completa a transparência da informação provada. Há também demanda por informações transparentes pelos intermediários como analistas financeiros e agência de rating, que se engajam em produzir informações privadas na busca de diminuir a superioridade de informação detida pela gerência. 


\subsubsection{Os fatores relacionados às decisões dos gerentes sobre transparência}

A literatura relacionada aos fatores que explicam determinadas decisões de transparência por parte dos gestores busca explicar as motivações que eles possuem para tomar decisões em relação ao nível de transparência.

Para Watts e Zimmerman (1990, p. 132), os gestores da empresa comparam o custo de prover e tornar pública a informação com o efeito que a abertura dessa informação causaria no valor das ações da empresa. Dessa forma, a abertura voluntária de informações acontece quando os gestores avaliam que o efeito da divulgação da informação no valor de mercado será maior do que o custo da mesma. Do contrário, as empresas não abrem voluntariamente a informação quando o custo é maior que o efeito do valor da empresa. Quando isso ocorre, faz-se necessária a obrigatoriedade de abertura de informação.

Fama (1970, p. 387) considera mercado eficiente aquele no qual não há custos de transação no comércio de títulos, todas as informações estão disponíveis para todos os participantes do mercado e todos concordam com as implicações de informação corrente para o preço corrente e distribuições de preços futuros para cada título. Num mercado assim, o preço corrente do título obviamente, reflete completamente, toda informação disponível. Assim, não seria possível obter ganhos anormais com base nesse tipo de informação.

A literatura relacionada à transparência voluntária tende a se focar no papel da divulgação de informações financeiras para o mercado de capitais. Tais estudos partem da premissa que, mesmo num mercado eficiente, os gestores detêm informação superior em relação aos investidores externos em termos de desempenho futuro esperado da companhia. Como as exigências regulatórias não são perfeitas em termos de garantir a transparência ideal para os investidores, presume-se que os gestores constantemente deparam-se com a decisão de equilibrar o nível de transparência fornecido ao mercado de capitais com o nível de informações que os mesmos detém na tomada de decisões estratégicas.

Healy e Palepu (1995, p. 137) argumentam que os gestores da empresa possuem incentivos de mercado para apresentar a as informações transparentes de forma voluntária e que a atitude 
dos gestores em relação a isso, altera-se de acordo com a percepção custo-benefício envolvida no processo.

Para Healy e Palepu (2001, p. 420) existem seis motivos que afetam as decisões dos gestores com relação à transparência das informações voluntárias para o mercado de capitais, são elas:

- Transações no mercado de capitais: prevê que a percepção do investidor a respeito da empresa é importante para os gestores quando estes esperam emitir títulos de dívida ou de ações ou mesmo adquirir outra empresa em uma transação envolvendo ações. É do interesse dos gestores assegurarem que preço das ações reflita o valor que os gestores implicitamente acreditam que a companhia deve valer;

- Competição/concorrência do controle corporativo: é motivada pela evidência de que o conselho de administração acompanha a atuação dos gestores através do desempenho das ações da empresa no mercado. Assim, dado o risco de perda do emprego decorrente de um desempenho ruim dos lucros e das ações no mercado, os gestores são motivados a abrir mais quantidade de informação a fim de reduzir a possibilidade de a ação estar sub-avaliada e também para explicar em detalhe o motivo do desempenho ruim dos lucros (quando é este o caso);

- Recompensa em ações: parte da premissa que os gestores são diretamente remunerados com planos de compensação baseados em ações, sejam eles opções de ações, as próprias ações ou remuneração ligada ao desempenho das ações da empresa. Assim, haveria motivação de abrir mais informações por parte dos gestores por diversos motivos, entre eles o fato de evitar que as ações estejam sub-avaliadas, incentivar o aumento da liquidez das ações e atender exigências legais a fim de poder realizar transações com as ações;

- Custo do processo: gestores atuando em favor dos atuais acionistas da empresa possuem incentivo a fazerem transparência voluntária a fim de reduzir os custos contratuais associados à compensação baseada em ações de novos empregados da empresa. Esse tipo de remuneração tem maior probabilidade de ser eficiente para os gestores e acionistas se o preço da ação for uma estimativa precisa do valor da firma. De outra forma, os gestores exigiriam uma remuneração adicional a fim de compensar o risco que 
eles estariam incorrendo associado ao problema de má avaliação da companhia pelo mercado;

- Custos sobre a propriedade: prevê que ameaça de litígio por parte dos acionistas tem dois efeitos na decisão de transparência dos gestores, um deles é que a ameaça de processos legais contra os gestores por abertura de informações inadequadas incentiva as empresas a proverem informações adequadas. Por outro lado, a ameaça de litígio reduz o incentivo dos gestores de abrirem informações, especialmente aquelas a respeito de projeções futuras;

- Sinalizar o talento administrativo: prevê que os gestores talentosos tendem a abrir mais informações de forma voluntárias, pois acreditam que quanto antes proverem informações aos acionistas, principalmente os externos, melhor estes irão avaliar a capacidade do gestor de antecipar mudanças futuras no ambiente de negócios e, assim, melhor será o valor de mercado da empresa.

\subsubsection{Conseqüiências da transparência na redução do custo de capital}

Healy e Palepu (2001, p. 429) destacam as conseqüências econômicas do aumento da transparência voluntárias das empresas, são elas: aumento da liquidez das ações, redução do custo de capital e aumento da cobertura por parte dos analistas de mercado.

Diamond e Verrechia (1991) argumentam que o custo de capital das empresas poderia diminuir à medida que houvesse um aumento da liquidez das ações transacionadas no mercado. A teoria dos autores é que os investidores passariam a confiar na organização caso essa se esforçasse ao máximo para diminuir (ou até mesmo eliminar) a assimetria informacional. Isso faria com que a confiança dos investidores institucionais aumentasse, já que teriam condições de pagar um preço justo pelas ações. Os investidores passariam então a investir na companhia, aumentando a liquidez das ações e essa demanda tenderia a diminuir o custo de captação por parte da organização. 
Botosan (1997, p. 324) corrobora com Diamond e Verrechia (op. cit.) quando diz que outro fator que poderia causar a diminuição de custo do capital próprio seria que o aumento da transparência elevaria a liquidez das ações, diminuindo seu custo de capital, através da redução dos custos de transação ou através do aumento da demanda pelas ações da empresa.

Barry e Brown (1985) argumentam que a redução do custo de capital pode ocorrer porque os investidores demandam um retorno adicional pela existência de risco informacional (não diversificável), já que o custo de estimação dos resultados da empresa seria maior. Assim, empresas com maior abertura de informações teriam custo de capital menor do que as empresas com risco informacional maior.

Quanto ao aumento da cobertura de analistas, Lang e Lundholm (1993) argumentam que a abertura de informações voluntárias pelos gestores diminui o custo de aquisição das mesmas pelos analistas, aumentando assim sua oferta. Os autores evidenciam ainda que empresas com mais abertura de informações possuem maior cobertura por parte dos analistas, menor dispersão nas projeções e menor volatilidade na revisão das estimativas dos analistas.

Verrechia (2001, p. 146) argumenta que existem efeitos negativos da transparência voluntária, dado que a companhia está transmitindo informações de alto valor para a concorrência, prejudicando potencialmente sua posição competitiva no mercado.

Porém, toda essa discussão sobre transparência fez com que fosse necessário criar formas ou mecanismos de se medir, ou mesmo estimar de alguma maneira o nível de transparência das organizações, como forma de destacar os acionistas, gerentes das organizações ou mesmo para os demais stakeholders, as empresas que mais se destacavam na evidenciação informações financeiras relevantes.

\subsection{Custo de oportunidade do capital}

O termo custo de oportunidade tem despertado interesse de economistas desde longa data. Das primeiras noções de custo de oportunidade trazidas por Keynes passando pelos primeiros esboços da definição mensuração do conceito de custo de oportunidade, no final do século 19, 
até os dias de hoje, muito tem se discutido e estudado tanto no meio acadêmico quanto no meio empresarial.

Financistas, economistas, contadores, gestores, governantes, professores e uma série de estudiosos do assunto têm contribuído, cada um da sua maneira, para a disseminação e assimilação dos pressupostos do custo de oportunidade para a sociedade como um todo, aprimorando a esquematização de uma noção intuitiva inicial para modernas técnicas de mensuração e utilização na tomada de decisões.

O marco histórico do custo de oportunidade coube a Frederic Von Wieser, um austríaco nascido em 1851. Foi ele quem introduziu o conceito de custo de oportunidade para definir o valor de um recurso produtivo para a teoria econômica. Wieser e seus seguidores promoveram uma revolução na análise econômica ao colocarem a análise das necessidades humanas como principal objeto de estudo da Ciência Econômica. Sendo assim, procuraram abordar as características subjetivas dos indivíduos e correlacioná-las com as escalas de preferências por diversos bens baseados no princípio da utilidade decrescente.

Martins (2003, p. 234), afirma que o custo de oportunidade representa o quanto a empresa sacrificou em termos de remuneração por ter aplicado seus recursos numa alternativa ao invés de em outra. Na comparação entre duas alternativas de investimento, importante que se atente para o risco das oportunidades e para o uso de moeda em mesmo poder aquisitivo, ou seja, livres do efeito inflacionário.

O custo de oportunidade pode ser entendido como o valor que determinado agente econômico deixou de ganhar caso tivesse aplicado seus recursos em outra proposta de investimento de mesmo risco e mesma liquidez. O entendimento custo de oportunidade é a base que torna possível toda a discussão sobre custo de capital que será feita a seguir.

\subsubsection{Custo de capital}

Segundo Atkinson et al. (2000, p.534), custo de capital é o retorno que a empresa deve ganhar sobre seus investimentos para satisfazer às exigências de retorno de seus investidores. É a taxa 
de juros que as empresas usam para calcular, descontando ou compondo, o valor do dinheiro no tempo.

Para Assaf Neto (2003, p. 355) o custo de capital de uma empresa reflete, em essência, a remuneração mínima exigida pelos proprietários de suas fontes de recursos (credores e acionistas). A qualidade dos investimentos empresariais é avaliada pela comparação entre o retorno promovido por estas decisões e o custo total de capital da empresa, determinado com base no custo de oportunidade de suas fontes de financiamentos.

Uma empresa possui três formas possíveis de financiamento das suas atividades. Uma advém de recursos de terceiros, tais como empréstimos obtidos em instituições financeiras ou recursos captados por emissão de títulos de dívida, por exemplo. Uma segunda fonte de financiamento advém da integralização de capital dos proprietários ou pela emissão de ações. E, por fim, uma última fonte de financiamento se dá por meio do reinvestimento dos lucros gerados pelas suas atividades.

A primeira e a segunda forma de financiamento representam um aporte de capital na empresa que deve ser remunerado. A remuneração do capital de terceiros, recebe o nome de custo de capital de terceiros. Trata-se, por exemplo, dos juros exigidos pelos bancos na liberação de empréstimos ou do rendimento oferecido pelas empresas na emissão de debêntures (títulos de dívida).

Já o aporte de recursos dos acionistas ou proprietários, recebe o nome de custo de capital próprio. Esse custo de capital é geralmente representado pelo custo de oportunidade visto anteriormente. A proporção entre esses recursos na composição patrimonial da empresa (passivo) ponderada pelo custo de cada fonte de financiamento, recebe o nome de custo médio ponderado de capital. Esses custos serão analisados individualmente e com maiores detalhes na seqüência.

\subsubsection{Custo do capital de terceiros}


O custo de capital de terceiros, como o próprio nome sugere, representa o custo advindo dos recursos obtidos de pessoas externas à empresa, tais como bancos, financeiras e outros. Na estrutura de financiamento de uma empresa, o capital de terceiros aparece geralmente como empréstimos, financiamentos e debêntures, tanto de curto quanto de longo prazo.

O custo de capital de terceiros é facilmente obtido. Ele é expresso pelas taxas de juros pagas nos empréstimos e financiamentos ou no rendimento prometido na emissão de debêntures pela empresa. Esse custo representa, em outras palavras, um custo explícito obtido pela taxa de desconto que iguala, em determinado momento, os vários desembolsos previstos de capital e de juros, com o principal liberado para a empresa.

Para Assaf Neto (2003, p. 356), o uso de capital de terceiros promove maior risco financeiro às empresas. Na decisão de endividamento, o tomador assume um compromisso de desembolso financeiro em condições fixas e previamente estabelecidas, ficando seu retorno, no entanto, vinculado ao sucesso da aplicação desses recursos. Ao não resgatar sua dívida nas condições em que foi contratada, a empresa sujeita-se a ser acionada legalmente pelo credor, podendo inclusive ter sua falência decretada.

Gitman (2002, p. 431) aponta que o custo do capital de terceiros é consideravelmente menor do que o custo de quaisquer outras fontes de financiamento. Isso deve-se basicamente ao fato de que os credores têm menor risco de perdas em relação aos proprietários da organização. Esse risco menor por parte dos credores se dá porque eles têm direito prioritário sobre os lucros ou ativos existentes para pagamentos, em caso de falência da empresa e também porque eles podem exercer mais pressão que os acionistas preferenciais ou ordinários para receber pagamento da empresa. Além desses fatores, o pagamento dos juros reduz o lucro tributado, o que diminui o valor a ser pago para o imposto de renda, representando um benefício fiscal adicional.

No entanto, Assaf Neto (op. cit., p. 358) alerta que uma das grandes preocupações das empresas, principalmente as brasileiras, é com o alto nível das taxas de juros do mercado, que pode inviabilizar a atratividade econômica do investimento de capital. Efetivamente, desde o início da década de 80, os negócios empresariais no Brasil têm-se desenvolvido em ambiente de elevado custo do dinheiro, situando-se com certa freqüência em percentual bem acima do retorno geralmente oferecido pelos ativos. Essa situação determinou, ao longo do tempo, um 
forte desestímulo econômico no uso de capital de terceiros para lastrear as decisões de investimentos das empresas brasileiras, reduzindo sua capacidade de alavancagem financeira e, em conseqüência, sua competitividade.

\subsubsection{Custo do capital próprio}

O capital próprio consiste nos recursos que a empresa dispõe e que foram advindos dos proprietários da empresa, ou seja, seus acionistas. Ao contrário dos recursos oriundos de terceiros, os capital próprio não tem uma data definida para ser devolvido. Pelo contrário, espera-se que esses recursos permaneçam por tempo indeterminado na empresa. Outra diferença entre capital próprio e capital de terceiros é que aquele não sujeita-se a pagamento de juros periodicamente.

As duas fontes básicas de capital próprio para uma companhia aberta são as ações preferenciais e ordinárias. Porém, todo acionista e proprietário da empresa e, assim, o custo do capital próprio tende a ser maior que o do capital de terceiro porque o risco incorrido pelos acionistas é bem maior que o dos credores.

Além disso, a determinação do custo de capital não pode ser realizada de forma direta, como acontece com o custo do capital de terceiros. Não existe uma regra única e generalizada para se determinar com exatidão o custo do capital dos acionistas. Isso é feito por meio de modelos desenvolvidos ao longo de décadas por financistas, que tentam de alguma maneira estimar o custo de oportunidade dos recursos aplicados nas organizações pela compra de ações.

Para Assaf Neto (2003, p. 388), o custo de capital próprio pode ser definido pelo retorno requerido por seus acionistas ao investirem seus recursos no empreendimento. Ao levantar recursos no mercado acionário, ou mesmo, ao reter parte de seus lucros, a empresa deverá aplicar em projetos (ativos) rentáveis, de modo que o retorno produzido possa remunerar seus acionistas em nível equivalente a suas expectativas. Dessa forma, a remuneração mínima exigida pelos acionistas constitui, em última análise, o custo do capital próprio da empresa. 
Antes de discorrer-se sobre alguns modelos utilizados na determinação do custo do capital próprio levantados na literatura e aplicados na realidade das empresas, será abordado o custo de capital total da empresa.

\subsubsection{Custo do capital total para a empresa}

O custo total de capital da empresa, apresentado na literatura como Weighted Average Cost of Capital (WACC), é tradicionalmente obtido mediante o cálculo da média dos custos de captação, ponderada pela participação de cada fonte de fundos na estrutura de capital a longo prazo. Nessa determinação, os investidores de capital próprio (acionistas) devem exigir uma remuneração maior que os credores (capital de terceiros), baseados em dois importantes argumentos.

Se uma empresa utilizar tanto capital próprio quanto capital de terceiros para financiar seus investimentos, o custo de capital será uma média ponderada dos custos desses dois tipos de capital.

Para Assaf Neto (2003, p. 366), o custo total de capital representa a taxa de atratividade da empresa, que indica a remuneração mínima que deve ser exigida na alocação de capital, de forma a maximizar seu valor de mercado. $\mathrm{O}$ custo médio ponderado de capital é então calculado de acordo com os custos de cada fonte de financiamento (própria e de terceiros) levando em conta a participação relativa de cada fonte de capital no financiamento total, de acordo com a expressão 1 .

$$
W A C C=\left[K e \times \frac{\mathrm{PL}}{\mathrm{P}+\mathrm{PL}}\right]+\left[K i(1-\mathrm{IR}) \times \frac{\mathrm{P}}{\mathrm{P}+\mathrm{PL}}\right]
$$

Onde:

$$
\begin{aligned}
& \mathrm{Ke}=\text { custo do capital próprio } \\
& \mathrm{Ki}=\text { custo do capital de terceiros } \\
& \mathrm{P}=\text { montante de passivos onerosos } \\
& \mathrm{PL}=\text { montante de patrimônio líquido } \\
& (1-\mathrm{IR})=\text { benefício fiscal dos juros }
\end{aligned}
$$


$\mathrm{O}$ quociente $\mathrm{PL} / \mathrm{P}+\mathrm{PL}$ identifica a proporção de capital próprio na estrutura de financiamento da empresa, enquanto que o quociente $\mathrm{P} / \mathrm{P}+\mathrm{PL}$ identifica a proporção de capital de terceiros, ou seja, onerosos, na estrutura de capital da organização1. O valor do patrimônio líquido geralmente é considerado o valor de mercado, ou seja, o total de ações emitidas multiplicado pelo valor de mercado da ação.

Note que o custo de capital de terceiros, Ki, é multiplicado por $(1-\mathrm{IR})$, pois os juros da dívida são dedutíveis para fins de cálculo de imposto de renda da pessoa jurídica. Entretanto, o custo de capital próprio, Ke, não é multiplicado por esse fator, pois os dividendos não são dedutíveis. No caso em que não há imposto de renda, o WACC não é afetado pelo grau de endividamento.

\subsection{Modelos para determinação do custo do capital próprio}

Um procedimento bastante utilizado na prática de determinação do custo de capital próprio é o método do fluxo de caixa descontado dos dividendos futuros esperados pelo mercado. Outro método de mensuração do custo de capital próprio é derivado da aplicação do modelo do precificação de ativos - CAPM, que estabelece uma relação linear entre o retorno de um ativo e o retorno do mercado. Os resultados desse modelo demonstram forte sensibilidade com a taxa requerida de retorno (custo de capital), a qual deve comportar-se de forma condizente com o risco. Quanto mais elevado apresentar-se o risco da decisão, maior ao retorno exigido pelos proprietários de capital (ASSAF NETO, 2003, p. 359).

Damodaran (2004, p.59) corrobora com o que diz Assaf Neto (op. cit.), referindo-se ao custo do patrimônio líquido (capital próprio) como sendo a taxa de retorno que os investidores exigem para realizar um investimento patrimonial em uma empresa. Com relação às formas para estimar o custo do patrimônio líquido, destaca duas abordagens, são elas: utilização de um modelo de risco e retorno (CAPM) e aplicação de um modelo de crescimento de dividendos.

\footnotetext{
${ }^{1}$ A soma dos pesos deve igualar-se a 1 , ou seja, todos os componentes da estrutura de capital devem ser levados em conta.
} 
O Capital Asset Pricing Model ou Modelo de Precificação de Ativos Financeiro é derivado da teoria do portfólio e busca, mais efetivamente, uma resposta de como devem ser relacionados e mensurados os componentes básicos (risco e retorno) de uma avaliação de ativos. Desse modelo teórico, é utilizado o $\beta$ (beta) como indicador do risco das empresas em estudo.

De acordo com Assaf Neto (ibid., p. 247), o CAPM é bastante utilizado nas várias operações do mercado de capitais, participando do processo de avaliação de tomada de decisões em condições de risco. Por meio do modelo, é possível também apurar-se a taxa de retorno requerida pelos investidores. O coeficiente beta, medida obtida do modelo, indica o incremento necessário no retorno de um ativo de forma a remunerar adequadamente seu risco sistemático.

O risco total de um ativo pode ser dividido em risco sistemático e não sistemático. $\mathrm{O}$ risco sistemático, também chamado de conjuntural, é a porção do risco determinada por eventos de natureza econômica, social e política que atingem as empresas como um todo, sendo impossível de se evitar. Já o risco não sistemático, ou diversificável, é de natureza própria de cada ativo e sua eliminação se dá por meio da diversificação de ativos com correlação negativa entre si.

O coeficiente beta $(\beta)$ é usado para medir o risco sistemático. É um índice do grau de movimento do retorno de um ativo em resposta à mudança no retorno de mercado. Quanto maior o risco de um ativo, mais alto será o retorno exigido e, portanto, maior o seu beta. Em contrapartida, quanto mais baixo o risco, mais baixo será o retorno exigido e, conseqüentemente, menor o valor do beta.

Assaf Neto (2003, p 271) elenca as aplicações do CAPM, uma delas é a oportunidade de se conhecer a taxa de retorno requerida pelos proprietários da empresa, ou seja, seu custo de capital próprio. Essa medida financeira apresenta enorme importância nas decisões financeiras das empresas e em seu processo de avaliação de desempenho. Por meio do beta é possível conhecer-se ainda o risco da empresa.

Ross et al. (1995, p. 224) afirmam que o retorno esperado de um título deve depender diretamente de seu risco. Ou seja, indivíduos deterão um título com risco somente se seu retorno esperado proporcionar uma compensação adequada pelo risco existente. Esse 
raciocínio é válido qualquer que seja a medida de risco adotada. O beta de um título é uma medida apropriada de risco, portanto, o retorno esperado de um título deve estar positivamente associado ao seu beta.

Damodaran (2004, p. 69) também cita que o beta de uma empresa é determinado por três variáveis: o tipo de negócio da empresa, o grau de alavancagem operacional na empresa e a alavancagem financeira da empresa, corroborando com o que Ross et al. (op. cit.) afirmam.

Assaf Neto (op. cit., p. 361) ressalta que a aplicação do modelo de precificação de ativos (CAPM) para a estimação do custo de capital próprio no Brasil embute algumas limitações que afetam, de forma significativa, a qualidade do resultado apurado. Esses problemas concentram-se, principalmente, no precário disclosure das companhias de capital aberto de todas as suas informações relevantes aos investidores, no alto grau de concentração das ações negociadas no mercado, na baixa competitividade do mercado e na inexpressiva representatividade das ações ordinárias (com direito a voto) nos pregões.

Uma metodologia bastante adotada ao se estimar o custo de capital próprio no Brasil é buscar uma referência das informações demandadas pelo modelo do CAPM em outros mercados financeiros que não apresentam as limitações presentes no mercado brasileiro. Em geral, é adotado como benchmark o mercado acionário norte-americano para se estimar o risco e o custo de capital de nossas empresas.

Esse critério é bastante usual entre os analistas financeiros, e recomendado em diversos trabalhos acadêmicos, sendo utilizado também na avaliação das empresas inseridas no programa nacional de privatização. Para o cálculo do custo do capital próprio no Brasil, acrescenta-se ao modelo do CAPM o $\alpha$ BR que representa o prêmio pelo risco Brasil, conforme é normalmente identificado pelos analistas financeiros (ASSAF NETO, 2003, p. $361)$.

Para Fleuriet (2004, p. 100) o CAPM estabelece uma relação lógica entre a taxa de retorno esperada e a volatilidade do portfólio. Quanto maior esta última, maior deverá ser a esperança matemática de altos retornos. O CAPM mostra que os retornos esperados de um portfólio deveriam exceder aqueles de um investimento livre de risco; isto pode ser atribuído a um prêmio de risco, cujo montante é proporcional ao coeficiente beta. O coeficiente beta 
(coeficiente estimado para as variáveis independentes numa equação de regressão) é o grau de sensibilidade às flutuações gerais do mercado de um dado papel. Ele mede, em termos históricos, o risco sistemático de dado papel com base na comparação entre as flutuações dos preços do papel e as flutuações do mercado financeiro como um todo.

\subsubsection{Estudos sobre o custo do capital próprio no Brasil}

Dois trabalhos publicados por Sanvicente e Minardi em 1999, sobre os problemas de estimação do custo do capital no Brasil são de extrema importância para a discussão do tema.

Sanvicente e Minardi (1999a, p. 1) iniciam a apresentação de seu modelo de determinação do custo de capital do acionista no Brasil afirmando que as empresas e os seus administradores estão cada vez mais contagiados pela busca da criação de valor, sendo que essa geração de valor é conseguida toda vez que se toma uma decisão com valor presente líquido positivo, ou seja, toda vez que a decisão produz rentabilidade superior ao custo de capital do acionista.

O objetivo dos autores é determinar qual é o custo do capital do acionista, que reflete a remuneração mínima que ele deseja ter para investir seu dinheiro na empresa. Como o retorno do investimento na empresa é incerto, os acionistas desejam ter uma expectativa de retorno pelo menos igual à oferecida por oportunidades de investimento de risco semelhante, existentes no mercado financeiro.

Porém não existe maneira de observar o custo do capital diretamente no mercado, sendo necessário que se adote algum modelo para estimá-lo. Sanvicente e Minardi (ibid., p. 2) usaram então a Linha de Mercado de Títulos - SML, ou seja, o CAPM (modelo de precificação de ativos com risco), de acordo com a expressão 2.

$$
\mathrm{R} i=\mathrm{R} f+(\mathrm{Rm}-\mathrm{R} f) * \mathrm{BETA} i
$$

Onde: $\mathrm{R} i=$ retorno esperado do ativo $i$

$\mathrm{R} f=$ retorno do ativo livre de risco

$\mathrm{R} m=\mathrm{o}$ retorno esperado da carteira de mercado. 


\section{$(\mathrm{R} m-\mathrm{R} f)$ Prêmio pelo risco do mercado}

BETA $i=$ coeficiente beta do ativo $i$

O retorno esperado do ativo i seria igual ao retorno do ativo livre de risco mais o prêmio pelo risco do ativo i, representado na expressão por $(\mathrm{R} m-\mathrm{R} f) *$ BETA $i$. O prêmio pelo risco de um ativo poderia, portanto, ser estimado pelo produto entre o beta do ativo e o prêmio estimado por unidade de risco de mercado.

Sanvicente e Minardi (ibid., p. 4) utilizam, para o ativo livre de risco, a Yield-to-Maturity (rendimento até o vencimento) do Brazil 27, o título de dívida externa de prazo mais longo de vencimento (aproximadamente 29 anos) como benchmark da taxa livre de risco. Eles justificam essa utilização, ao invés do uso de títulos do Tesouro americano, por exemplo, ao considerar um risco soberano adicional existente no mercado brasileiro.

Sanvicente e Minardi (1999a, p. 5) consideram que no Brasil não existem séries históricas de dados tão longa quanto em outras economias desenvolvidas, e como nossa economia enfrenta muito mais turbulências do que a economia americana, por exemplo, o autor estima o retorno esperado da carteira de mercado por meio do modelo de crescimento de dividendos para uma amostra de 60 empresas que apresentaram lucro por ação positivo, de acordo com a expressão 3.

$$
\mathrm{P}_{\mathrm{ação}}=\mathrm{D} 1 /(r-g)
$$

Onde: $\mathrm{D} 1$ = dividendo a ser pago no próximo período; $r=$ taxa de desconto exigida pelo acionista ou custo do capital próprio; $g=$ taxa de crescimento dos dividendos.

Desta maneira, conhecendo-se o preço da ação, estimando-se g e D1, pode-se estimar r pela expressão 4 .

$$
r=\left(\mathrm{D} 1 / \mathrm{P}_{\mathrm{ação}}\right)+g
$$

Os autores apresentam duas metodologias para calcular a taxa de crescimento sustentável $(g)$. A primeira metodologia de Sanvicente e Minardi (ibid., p. 5) baseia-se na taxa de crescimento 
sustentável, ou seja, a maior taxa de crescimento que uma empresa pode conseguir sem alterar sua estrutura de capital e o índice de retenção de $\operatorname{lucros}^{2}$, obtido conforme a expressão 5.

$$
g=\operatorname{ROE} \times(1-\mathrm{D} / \mathrm{L})
$$

Onde: $\mathrm{ROE}$ = rentabilidade sobre o patrimônio líquido, obtida dividindo-se o lucro líquido pelo patrimônio líquido no início do período.

$\mathrm{D}=$ dividendo por ação

$\mathrm{L}=$ lucro por ação

$\mathrm{D} / \mathrm{L}=$ payout da empresa

$(1-\mathrm{D} / \mathrm{L})=$ índice de retenção de lucro,

Na segunda metodologia, de acordo com Sanvicente e Minardi (1999b, p. 6), os autores procuraram calcular o retorno do mercado usando as projeções diretas de analistas de mercado ao invés de perguntar indiretamente ao mercado qual seria o retorno esperado da carteira de mercado. Para esse fim, os autores usam o dividend yield (D/P) e a taxa de crescimento $(g)$ para todas as ações que tinham projeções de dividendo por ação e apresentaram lucro positivo em 1998.

Considerando que o dividendo de cada uma dessas ações seja igual à média dos dividendos por ação projetados pelos analistas para 1999, os autores estimaram o crescimento dos dividendos de cada ação como sendo igual a [(D1/D0) - 1], ou seja, à taxa de crescimento de dividendos projetada pelos analistas. Assim, o dividend yield e a taxa de crescimento para o mercado como um todo foram calculados como sendo as médias dos dividend yield e das taxas de crescimento das diversas ações.

O prêmio pelo risco de mercado é a diferença entre o retorno de uma carteira que representa o mercado e o do ativo livre de risco (definido por benchmark). Os autores tomaram como retorno do ativo livre de risco o YTM do título Brazil 27, conforme dito anteriormente.

\footnotetext{
${ }^{2}$ Para maiores esclarecimentos sobre a metodologia utilizada para estimativa da taxa de crescimento sustentável, Sanvicente e Minardi propõe a consulta de Higgins, R. C., Analysis for Financial Management, IRWIN, 1995, 4ª edição.
} 
O risco total de um projeto é medido pelo desvio-padrão das taxas de retorno deste projeto. Este risco possui dois componentes: o primeiro é o que pode ser eliminado com a diversificação do investimento, pois afeta apenas o projeto ou poucos ativos, e é denominado risco não sistemático; o segundo é aquele que afeta o mercado como um todo e não pode ser eliminado com a diversificação, sendo denominado risco sistemático. O beta indica a contribuição que o título traz à carteira de mercado, em termos de .

Segundo Sanvicente e Minardi (ibid., p. 2), o risco sistemático de um título pode ser medido pelo valor de seu coeficiente beta, que por sua vez pode ser estimado pelo coeficiente de regressão linear entre a taxa de retorno do investimento e a taxa de retorno de uma carteira que represente o mercado, normalmente o IBOVESPA (Índice de ações da BOVESPA).

O modelo de Sanvicente e Minardi para cálculo do custo do capital próprio faz uso de algumas variáveis que dão margem à discussão. No cálculo do retorno esperado da carteira de mercado, utilizado para a Telebrás, eles utilizam-se de uma amostra de 60 ações que apresentaram lucro por ação positivo e não fornecem maiores informações do porquê não utilizaram todas as empresas do mercado, inclusive as com prejuízo no período.

Um outro ponto a ser discutido é a criação de um índice com 67 ações da BOVESPA com ponderação igual na carteira e média aritmética dos retornos das ações. Porém, como a metodologia proposta pelos autores utiliza dados correntes do próprio mercado de capitais, sua aplicação e verificação torna-se possível sem maiores dificuldades. Por esses motivos, optou-se pela não utilização da metodologia de estimação do custo do capital próprio de Sanvicente e Minardi e sim pela metodologia proposta por Assaf Neto, que será vista a seguir.

\subsubsection{Metodologia de determinação do custo do capital próprio por benchmark}

Conforme exposto por Assaf Neto (2003, p. 64) o custo de capital é adotado como um método de medição de propostas de investimentos. Sua função básica é servir como um mecanismo racional para se determinar a atratividade econômica de qualquer proposta que exija a utilização de recursos financeiros e que se tenha por objetivo a maximização de seu retorno. 
Para a determinação do custo do capital de terceiros, utilizou-se neste trabalho, o Modelo de Precificação de Ativos, ou Capital Asset Pricing Models - CAPM adaptado ao Brasil, ou seja, utilizando dados americanos e acrescentando ao custo de capital próprio encontrado um prêmio pelo risco Brasil, conforme proposto e utilizado por Assaf Neto (2003).

O modelo do CAPM leva em consideração a existência de uma taxa livre de risco, um prêmio pelo risco de mercado e uma medida de risco da empresa, representado pelo coeficiente beta. Para estimação do custo do capital próprio no Brasil, adiciona-se um prêmio. Sua expressão de cálculo é a seguinte:

$$
K_{e}=\left[R_{F}+\beta \times\left(R_{M}-R_{F}\right)\right]+\alpha_{B R}
$$

Onde: $K_{e}=$ custo do capital de terceiros pelo método do CAPM

$$
\begin{aligned}
& R_{F}=\text { taxa de retorno de um ativo livre de risco } \\
& \beta=\text { coeficiente beta do título } \\
& R_{M}=\text { taxa de retorno da carteira de mercado } \\
& R_{M}-R_{F}=\text { prêmio pelo risco de mercado } \\
& \alpha_{B R}=\text { prêmio pelo risco-brasil }
\end{aligned}
$$

O CAPM é um dos modelos mais utilizados em avaliações de decisões que envolvem risco e na determinação da taxa de retorno requerida por investidores de capital. Sua formulação indica que o retorno esperado de um título (ou outra aplicação) está positivamente relacionado a seu beta. A seguir, serão detalhados os componentes do Modelo de Precificação de Ativos. Uma taxa considerada risk free é aquela em que os investidores não incorrem nenhum risco ao aplicar seus recursos. Ou seja, existe a certeza do pagamento do principal mais juros por parte do tomador do capital.

O risco total de um ativo pode ser dividido em risco sistemático e não sistemático. O risco sistemático, também chamado de conjuntural, é a porção do risco determinada por eventos de natureza econômica, social e política que atingem as empresas como um todo, sendo impossível de se evitar. Já o risco não sistemático, ou diversificável, é de natureza própria de 
cada ativo e sua eliminação se dá por meio da diversificação de ativos com correlação negativa entre si.

O coeficiente beta $(\beta)$ é usado para medir o risco sistemático. É um índice do grau de movimento do retorno de um ativo em resposta à mudança no retorno de mercado. Quanto maior o risco de um ativo, mais alto será o retorno exigido e, portanto, maior o seu beta. Em contrapartida, quanto mais baixo o risco, mais baixo será o retorno exigido e, conseqüentemente, menor o valor do beta.

Os coeficientes betas podem ser obtidos de fontes de publicação sobre as ações negociadas ativamente ou por meio de empresas de corretagem. Essas empresas baseiam seus cálculos na sensibilidade da ação ordinária da empresa em relação aos movimentos da carteira de mercado. Porém, essa metodologia de avaliação tem alguns pressupostos que dificultam sua aplicação no Brasil.

Uma primeira condição básica é que a quantidade de ações ordinárias em circulação seja condizente com o total emitido. Depois, a posse dessas ações não pode estar concentrada nas mãos de poucos investidores, ou seja, o ideal é que elas estejam pulverizadas no mercado, já que isso permite que as ações ordinárias expressem com mais fidelidade o efetivo valor da empresa.

No mercado de capitais brasileiro, entretanto, essas condições não são observadas. O número de ações com direito a voto negociado em bolsa é muito reduzido em comparação ao total emitido e os papéis estão concentrados nas mãos de poucos investidores. Esse cenário compromete o cálculo do beta a partir das ações ordinárias, pois não reflete a realidade das empresas.

O retorno esperado de mercado é calculado a partir do retorno médio das ações ordinárias das empresas de capital aberto negociadas livremente nas bolsas de valores e representada pela carteira de mercado. Nos Estados Unidos, o índice mais comumente utilizado é o NYSE New York Stock Exchange. 
No Brasil, o índice que representa com mais fidedignidade o retorno de mercado é o IBOVESPA - Índice da Bolsa de Valores de São Paulo. Porém, o mercado acionário brasileiro incorre em algumas limitações, como precária divulgação das companhias de capital aberto, poucas ações ordinárias em circulação e baixo índice de pulverização de ações com direito a voto.

O prêmio pelo risco de mercado acionário, obtido pela diferença entre o retorno de mercado e a taxa livre de risco $\left(R_{M}-R_{F}\right)$, reflete o retorno adicional que o investidor deve auferir como forma de compensar o risco assumido ao investir seu dinheiro em economias que apresentar um nível maior de incerteza.

O risco país reflete a capacidade de uma nação em honrar seus compromissos externos. Quanto maior for a desconfiança dos investidores em relação ao país, maior será a remuneração exigida pelos investidores no empréstimo de seu dinheiro. Esse risco é medido pela diferença entre os juros pagos pelos papéis da dívida externa de determinado país e a taxa oferecida por um título livre de risco, geralmente o T-Bond (Treasury Bond) emitido pelo governo americano.

O principal título de dívida pública brasileira era o C-Bond (Capitalization Bond), negociado livremente no mercado internacional e considerado como o de maior liquidez. Quando o valor desse título se valoriza no mercado, demonstra um maior grau de confiança dos investidores com relação à capacidade brasileira de cumprir seus compromissos financeiros. Após outubro de 2005, quando houve o pagamento e resgate desses títulos, o título mais negociado atualmente passou a ser o Global40.

Quadro 2 - Comparação entre as metodologias de determinação do custo do capital próprio

\begin{tabular}{|l|l|l|l|}
\hline & $\begin{array}{l}\text { Metodologia de Sanvicente } \\
\text { e Minardi }\end{array}$ & $\begin{array}{l}\text { Metodologia de Assaf Neto } \\
\text { (benchmark) }\end{array}$ & Premissas do modelo CAPM \\
\hline Risk free & $\begin{array}{l}\text { Yield-to-Maturity do Brazil } \\
27\end{array}$ & $\begin{array}{l}\text { T-Bond (títulos do tesouro } \\
\text { do governo americano) }\end{array}$ & $\begin{array}{l}\text { Taxa de retorno de um ativo } \\
\text { livre de risco }\end{array}$ \\
\hline Beta & $\begin{array}{l}\text { Regressão de 60 ações de } \\
\text { empresas brasileiras com o } \\
\text { índice IBOVESPA }\end{array}$ & $\begin{array}{l}\text { Obtido de empresas } \\
\text { especializadas (Bloomberg, } \\
\text { S\&P, Value Line, Merril } \\
\text { Lynch e outras) }\end{array}$ & $\begin{array}{l}\text { Coeficiente beta da regressão } \\
\text { linear do título em relação à } \\
\text { carteira de mercado. É uma } \\
\text { medida do risco sistemático. }\end{array}$ \\
\hline $\begin{array}{l}\text { Retorno de } \\
\text { mercado }\end{array}$ & $\begin{array}{l}\text { Taxa de crescimento } \\
\text { sustentável ou projeções de } \\
\text { analistas }\end{array}$ & $\begin{array}{l}\text { Retorno do índice Standard } \\
\text { \& Poor's 500 }\end{array}$ & $\begin{array}{l}\text { Taxa de retorno da carteira de } \\
\text { mercado }\end{array}$ \\
\hline$\alpha_{B R}$ & Não utiliza & $\begin{array}{l}\text { Spread entre o rendimento } \\
\text { do T-Bond e o C-Bond }\end{array}$ & Prêmio pelo risco-Brasil \\
\hline
\end{tabular}


Os parâmetros utilizados na composição do cálculo do custo do capital próprio por meio do modelo CAPM por benckmark serão descritos no capítulo da metodologia. Por hora, faz-se necessário elucidar as diferenças entre as metodologias de cálculo do custo do capital próprio encontradas na literatura brasileira dentro das premissas do modelo do Capital Asset Pricing Model, conforme o quadro 2.

\subsection{Estudos relacionados à comparação entre transparência e custo de capital}

Existe uma série de estudos que confirmam a teoria de que há uma relação negativa entre transparência e custo de capital, que serão aqui apresentados e neste trabalho optou-se por uma separação da literatura estrangeira e nacional.

\subsubsection{Estudos realizados no exterior}

A teoria que embasa a esperada relação inversa entre custo do capital próprio e transparência foi descrita por Botosan (1997, p. 324) que caracterizou duas linhas de pesquisa. A primeira diz que maior transparência aumenta a liquidez de mercado das ações, através disso, reduz o custo de capital pela redução dos custos de transação ou demanda aumentada pelos títulos da empresa, de acordo com Amihud e Mendelson (1986) e Diammond e Verrecchia (1991).

A segunda linha de pesquisa descrita nesse artigo, segundo diversos autores como Klein e Bawa (1976), Barry e Brown (1985), Coles e Loewentein (1988), Handa e Linn (1993) e Coles et al. (1995), sugere que maior transparência pode reduzir o custo de capital pela redução do risco não diversificável de estimativa.

Botosan (1997, p. 323) examinou a associação entre o custo de capital próprio e o nível de transparência, por meio de regressão de estimativas específicas para a firma do custo do capital próprio com relação ao beta de mercado, o tamanho da empresa e uma medida criada para mensurar o nível de transparência. Sua mensuração do nível de transparência é baseada na quantidade de informações voluntárias disponíveis nos relatórios anuais de 1990 de uma 
amostra de 122 indústrias listadas na edição de 1994 do Ward's Business Directory nos Estados Unidos.

Esse artigo fornece evidências diretas sobre a associação entre custo de capital próprio e nível de transparência e indica a magnitude desse efeito. A conclusão foi que para uma amostra de empresas que atraem baixo nível de reporte por parte dos analistas de mercado, as evidências sugerem que maior transparência é associada com menor custo de capital próprio. Já para uma amostra de empresas mais reportadas pelos analistas de mercado, há uma relação não significante entre nível de transparência e custo do capital próprio. A autora justifica que isso pode ter ocorrido por ela basear-se apenas em relatórios anuais de um único ano, o que faz com que as proxies utilizadas não sejam tão poderosas.

O estudo também fornece algumas evidências preliminares dos tipos de transparência que parecem ter um importante papel na redução do custo do capital próprio. O estudo demonstra ainda o procedimento para estimar o custo do capital próprio que pode ser aplicado em outros contextos para outras empresas.

Num estudo seguinte, Botosan e Plumlee (2002, p. 21) exploram a associação entre o custo do capital próprio esperado e três tipos de transparência, a contida nos relatórios anuais, nos relatórios trimestrais e outras publicações e a relação com investidores em 43 indústrias tiradas do Annual Rewiews of Corporate Reporting Practices no período de 1986 a 1996 nos Estados Unidos.

Contrariando as expectativas prévias, as autoras concluíram que maior transparência não está associada com menor custo de capital próprio. No entanto, as autoras encontraram limitações nas análises dependendo do tipo de transparência adotado. Existe uma associação negativa quando a análise com um corte transversal, ou seja, é analisado um único período. Uma associação positiva ocorre quando a análise é feita com uma série temporal.

As autoras ressaltam que, embora os resultados finais contrariem a teoria de que maior e melhor transparência reduz o custo do capital próprio, ela vem ao encontro das reclamações dos executivos, de que a informação mais tempestiva aumenta o custo do capital próprio, e atribuem a explicação desse fenômeno a um provável aumento da volatilidade do preço das ações. 
Chen et al. (2003, p. 11) examinaram o efeito da transparência e de outros mecanismos de governança corporativa não relacionados à transparência no custo do capital próprio nos mercados emergente da Ásia. A amostra foi composta de 270 empresas em 2000 e 275 em 2002, em 9 economias asiáticas.

A regressão dos resultados mostrou que a contagem mais elevada de transparência e dos mecanismos de governança corporativa não relacionados à transparência estão associados com um menor custo de capital próprio, depois de controlar os fatores tais como beta e tamanho da empresa.

Hail (2002, p. 2) diz que a relação entre qualidade da transparência e custo do capital próprio é um tópico importante na economia atual. Em geral, a teoria econômica e as evidências sugerem uma associação negativa entre essas duas variáveis. Entretanto, os estudos empíricos têm usado metodologias inconvenientes, pois nem o nível de transparência nem o custo do capital podem ser diretamente observados.

Nesse estudo, o autor tenta quantificar os efeitos das políticas de transparências voluntária das empresas e sua implicação na custo de capital e fornecer evidências sobre o relacionamento entre as duas variáveis. A amostra foi composta por 73 empresas não financeiras listadas na Swiss Exchange SWX, feito um corte transversal no ano de 1997. Nesse trabalho a associação entre as variáveis transparência e custo de capital foi negativa e altamente significativa.

Os estudos citados até então adotaram metodologias semelhantes para a apuração do custo de capital, o qual foi estimado encontrando-se a taxa de desconto que, aplicada às projeções de rendimento futuro das empresas feitas pelos analistas de mercado, iguala tal fluxo ao preço corrente das ações.

Francis et al. (2003, p. 2) analisaram uma amostra de 856 empresas em 34 países pertencentes a 18 setores industriais, com o objetivo de investigar se existe incentivo à transparência voluntária em função da necessidade de financiamento externo fora dos Estados Unidos, onde muitos países têm uma fraca proteção ao investidor e mercados financeiros menos desenvolvidos. 
Os autores afirmam existir duas razões porque não ocorre transparência voluntária fora dos Estados Unidos. A primeira é que a transparência contábil não tem credibilidade se o país tem um fraco ambiente de proteção ao investidor, que geralmente significa menor qualidade contábil. A segunda é que pode não haver nenhuma necessidade de se divulgar a transparência voluntária se as empresas operam em países onde predominantemente o Banco Central coordena o sistema financeiro.

Foi verificada uma correlação positiva entre as variáveis transparência e necessidade de financiamento externo, e empresas com maior transparência têm redução no custo de capital, concluíram os autores.

\subsubsection{Estudos realizados no Brasil}

Alencar e Lopes (2005, p. 1) investigaram se o nível de transparência influencia o custo do capital para as empresas negociadas no mercado brasileiro. A amostra foi composta por 222 empresas listadas na bolsa, com dados contábeis de 31 de dezembro de 2003. Os autores ressaltam a dificuldade em se empreender estudos ligando custo do capital próprio ao nível de transparência, uma vez que nenhuma das duas medidas é diretamente observável. Portanto, a qualidade das conclusões depende, em grande parte, da habilidade do pesquisador em escolher as proxys adequadas para as duas variáveis.

Alencar e Lopes (ibid., p. 10) verificaram que, com base nos dados pesquisados, no mercado brasileiro o nível de transparência não afeta o custo de capital. Em função das peculiaridades do mercado brasileiro, o resultado não é de todo surpreendente. Porém verificou-se outros dois resultados contrários à expectativa alicerçada na teoria, mas que reforçam os resultados de outras pesquisas já realizadas que são: as maiores empresas oferecem taxas de retorno superiores às menores e a implementação de práticas diferencias de governança corporativa não resultou em alteração do custo de capital.

Dentre os estudos conduzidos no Brasil, foi encontrado apenas o citado acima, que tentou especificamente relacionar transparência e custo de capital. No entanto, diversos estudos examinaram a influência de outros fatores no custo de capital. 
O trabalho de Bruni (2002, p. 63) teve por objetivo analisar os efeitos dos anúncios da emissão de ADR (American Depositary Receipts) sobre a eficiência alocacional do mercado, com análise dos efeitos das integrações dos diferentes mercados sobre o custo de capital de empresas globalizadas. A amostra do estudo foi composta por empresas brasileiras que emitiram ADR e solicitaram autorização da CVM para emissão de ADR.

Bruni (2002, p. 142) verificou que a emissão de ADR por empresas brasileiras representa, por um lado, a tomada de melhores decisões de financiamento, com a conseqüente redução do custo de capital. No entanto, por outro lado, a substituições de ações em bolsas brasileiras provoca o esvaziamento da liquidez do mercado local.

Silveira (2003) investigou se as empresas brasileiras com ações negociadas em bolsa e que emitiram ADR na década de 90 passaram por significativa modificação em seu custo de capital. Os resultados encontrados sugerem que, na média, as empresas apresentaram redução no custo de capital. Em sua conclusão o autor nota que as reduções observadas parecem vir mais de modificações operacionais internas, mais especificadamente, pela criação de novas regras de governança corporativa.

Lima et al. (2004) estudaram as taxas de captação das empresas que emitiram debêntures entre janeiro de 2001 e novembro de 2003, e não encontraram indícios significativos de que as empresas que aderiram a qualquer um dos níveis diferenciados de governança corporativa da BOVESPA tenham conseguido captar a taxas mais baixas que as demais empresas. 


\section{METODOLOGIA DA PESQUISA E RESULTADOS}

A pesquisa desenvolvida é quantitativa e com base em procedimento estatísticos, objetivando produzir inferências para a população objeto a partir da amostra considerada. Com relação ao enfoque epistemológico, a pesquisa é do tipo empírico-analítica, essa abordagem apresenta em comum a utilização de técnicas de coleta, tratamento e análise de dados marcadamente quantitativas, tem forte preocupação com a relação causal entre as variáveis e a validação da prova científica é buscada por meio de teste dos instrumentos, graus de significância e sistemas das definições operacionais (MARTINS, 1994, p. 26).

Especificamente, a pesquisa utiliza uma regressão múltipla do tipo seção transversal entre a variável dependente custo de capital e a variável independente transparência. Tem-se ciência de que um estudo série-temporal traria maior robustez aos resultados, no entanto, dada a limitação de uma série histórica para a variável transparência, a utilização da seção transversal é recomendada e foi amplamente utilizada em estudos com objetivo similar ao deste trabalho, como levantado na revisão bibliográfica.

Além disso, foram adicionadas ao modelo as variáveis de controle tamanho da empresa, grau de endividamento e relação entre o preço da ação e o valor patrimonial. O uso das variáveis de controle tem o objetivo de isolar sua influência sobre o relacionamento entre as variáveis mencionadas anteriormente.

Para Tapscott e Ticoll (2005, p. 80), a transparência depende da confiança. Na verdade, conforme as pessoas aprendem a colaborar ao longo do tempo, a transparência e a confiança se reforçam mutuamente, gerando um ciclo vicioso. Para os autores, a empresas não podem ser transparente quando não dignas de confiança, pois a abertura as prejudicaria. Empresas confiáveis devem ser transparentes porque a abertura ajuda os stakeholders a validar sua integridade. Em um mundo cada vez mais transparente, a abertura ativa torna-se central para o estabelecimento de confiança entre stakeholders e empresas, inclusive como forma de reduzir o custo de obtenção de capital.

\subsection{Composição da amostra}


A amostra foi composta por empresas que compunham o índice BOVESPA em 29 de dezembro de 2005. O índice IBOVESPA é composto das ações mais negociadas na Bolsa de Valores de São Paulo. A utilização das empresas desse índice se justifica por serem representativa do total das empresas brasileiras com ações negociadas na BOVESPA.

Dessa amostra inicial, foram extraídas as empresas do setor Financeiro, pois esse setor apresenta algumas particularidades em relação aos outros setores econômicos que inviabilizam a comparação direta. Entre as principais particularidades, pode-se citar a estrutura de capital homogênea que as Instituições Financeiras adotam, devido às exigências do Acordo da Basiléia. Como o nível de endividamento é uma das variáveis utilizadas nesse estudo, a inclusão dos Bancos poderia distorcer os resultados obtidos. Dessa forma, foram retiradas da amostra as empresas: Bradesco, Bradespar, Banco do Brasil, Itaú e Unibanco.

As regressões, que serão vistas mais adiante, foram realizadas utilizando-se as ações preferenciais para todas as empresas da amostra. Exceção feita apenas para as empresas: Arcelor BR, Light, Sabesp, Siderúrgica Nacional e Souza Cruz que não possuíam ações preferenciais em circulação no ano de 2005. Isso porque, no Brasil, as ações ordinárias são pouco negociadas no mercado acionário e pouquíssimas empresas têm o seu controle acionário negociado na Bolsa. Isso faz com que as ações ordinárias apresentem menor liquidez em relação às preferenciais, fazendo com que o valor de mercado da ação revele baixíssima relação com o efetivo valor da empresa, podendo distorcer as análises que serão realizadas nesse estudo.

Além disso, um estudo realizado por Alencar e Lopes (2005), onde foram regredidos o beta da empresa em função do disclosure, tendo como as variáveis de controle o tamanho da empresa, o grau de endividamento, a relação entre o preço da ação e valor patrimonial, uma dummy para Governança Corporativa e outra para internacionalização da empresa, mostrou que o poder de explicação do modelo completo, com todas essas variáveis, foi maior para as ações preferenciais do que para as ordinárias.

Com base nessas variáveis, obteve-se a estimativa do valor do custo do capital próprio para as 41 empresas da amostra final, conforme apresentado na tabela 1.

Tabela 1 - Cálculo do Custo do Capital Próprio 


\begin{tabular}{|c|c|c|c|c|c|c|}
\hline Empresa & $\begin{array}{l}\text { Risk free } \\
\text { (T-bond) }\end{array}$ & $\begin{array}{c}\text { Retorno } \\
\text { Mercado } \\
\text { (S\&P500) }\end{array}$ & $\begin{array}{c}\text { Beta } \\
\text { Desalavan- } \\
\text { cado } \\
\text { Americano }\end{array}$ & $\begin{array}{l}\text { Beta Alav. } \\
\text { pelo P/PL da } \\
\text { empresa }\end{array}$ & $\begin{array}{c}\text { Alfa BR } \\
(\text { G40 } \\
\text { spread) }\end{array}$ & $\begin{array}{c}\text { Custo do } \\
\text { Capital } \\
\text { Próprio }\end{array}$ \\
\hline Acesita & $4,57 \%$ & $5,55 \%$ & 0,91 & 1,12 & $4,04 \%$ & $9,71 \%$ \\
\hline Ambev & $4,57 \%$ & $5,55 \%$ & 0,56 & 0,69 & $4,04 \%$ & $9,29 \%$ \\
\hline Aracruz & $4,57 \%$ & $5,55 \%$ & 0,53 & 0,87 & $4,04 \%$ & $9,46 \%$ \\
\hline Arcelor BR & $4,57 \%$ & $5,55 \%$ & 0,91 & 1,04 & $4,04 \%$ & $9,63 \%$ \\
\hline Brasil T Par & $4,57 \%$ & $5,55 \%$ & 1,29 & 1,84 & $4,04 \%$ & $10,41 \%$ \\
\hline Brasil Telecom & $4,57 \%$ & $5,55 \%$ & 1,29 & 2,04 & $4,04 \%$ & $10,61 \%$ \\
\hline Braskem & $4,57 \%$ & $5,55 \%$ & 0,79 & 1,38 & $4,04 \%$ & $9,96 \%$ \\
\hline Caemi & $4,57 \%$ & $5,55 \%$ & 0,93 & 1,04 & $4,04 \%$ & $9,63 \%$ \\
\hline Celesc & $4,57 \%$ & $5,55 \%$ & 0,67 & 0,76 & $4,04 \%$ & $9,36 \%$ \\
\hline Cemig & $4,57 \%$ & $5,55 \%$ & 0,67 & 0,97 & $4,04 \%$ & $9,57 \%$ \\
\hline Cesp & $4,57 \%$ & $5,55 \%$ & 0,67 & 1,16 & $4,04 \%$ & $9,75 \%$ \\
\hline Comgas & $4,57 \%$ & $5,55 \%$ & 0,47 & 0,76 & $4,04 \%$ & $9,36 \%$ \\
\hline Copel & $4,57 \%$ & $5,55 \%$ & 0,67 & 0,83 & $4,04 \%$ & $9,43 \%$ \\
\hline CRT Celular & $4,57 \%$ & $5,55 \%$ & 1,29 & 1,39 & $4,04 \%$ & $9,98 \%$ \\
\hline Eletrobras & $4,57 \%$ & $5,55 \%$ & 0,67 & 0,83 & $4,04 \%$ & $9,43 \%$ \\
\hline Eletropaulo Metropo & $4,57 \%$ & $5,55 \%$ & 0,67 & 1,28 & $4,04 \%$ & $9,87 \%$ \\
\hline Embraer & $4,57 \%$ & $5,55 \%$ & 0,95 & 1,41 & $4,04 \%$ & $10,00 \%$ \\
\hline Embratel Part & $4,57 \%$ & $5,55 \%$ & 1,29 & 1,47 & $4,04 \%$ & $10,05 \%$ \\
\hline Gerdau & $4,57 \%$ & $5,55 \%$ & 0,91 & 1,36 & $4,04 \%$ & $9,95 \%$ \\
\hline Gerdau Met & $4,57 \%$ & $5,55 \%$ & 0,91 & 1,34 & $4,04 \%$ & $9,92 \%$ \\
\hline Ipiranga Pet & $4,57 \%$ & $5,55 \%$ & 0,87 & 1,11 & $4,04 \%$ & $9,70 \%$ \\
\hline Itausa & $4,57 \%$ & $5,55 \%$ & 0,37 & 0,38 & $4,04 \%$ & $8,98 \%$ \\
\hline Klabin & $4,57 \%$ & $5,55 \%$ & 0,53 & 0,80 & $4,04 \%$ & $9,39 \%$ \\
\hline Light & $4,57 \%$ & $5,55 \%$ & 0,67 & 1,57 & $4,04 \%$ & $10,15 \%$ \\
\hline Net & $4,57 \%$ & $5,55 \%$ & 1,25 & 2,30 & $4,04 \%$ & $10,86 \%$ \\
\hline Petrobras & $4,57 \%$ & $5,55 \%$ & 0,61 & 0,82 & $4,04 \%$ & $9,42 \%$ \\
\hline Sabesp & $4,57 \%$ & $5,55 \%$ & 0,49 & 0,74 & $4,04 \%$ & $9,34 \%$ \\
\hline Sadia & $4,57 \%$ & $5,55 \%$ & 0,52 & 1,00 & $4,04 \%$ & $9,59 \%$ \\
\hline Sid Nacional & $4,57 \%$ & $5,55 \%$ & 0,91 & 1,73 & $4,04 \%$ & $10,30 \%$ \\
\hline Souza Cruz & $4,57 \%$ & $5,55 \%$ & 0,6 & 0,84 & $4,04 \%$ & $9,44 \%$ \\
\hline Tele Centroeste Cel & $4,57 \%$ & $5,55 \%$ & 1,29 & 1,32 & $4,04 \%$ & $9,91 \%$ \\
\hline Tele Leste Celular & $4,57 \%$ & $5,55 \%$ & 1,29 & 2,32 & $4,04 \%$ & $10,88 \%$ \\
\hline Telemar Norte Leste & $4,57 \%$ & $5,55 \%$ & 1,29 & 1,84 & $4,04 \%$ & $10,41 \%$ \\
\hline Telemig Celul Part & $4,57 \%$ & $5,55 \%$ & 1,29 & 1,46 & $4,04 \%$ & $10,04 \%$ \\
\hline Telemar-Tele NL Par & $4,57 \%$ & $5,55 \%$ & 1,29 & 2,13 & $4,04 \%$ & $10,70 \%$ \\
\hline Telesp & $4,57 \%$ & $5,55 \%$ & 1,29 & 1,49 & $4,04 \%$ & $10,07 \%$ \\
\hline Tim Participacoes & $4,57 \%$ & $5,55 \%$ & 1,29 & 1,33 & $4,04 \%$ & $9,92 \%$ \\
\hline Transmissao Paulist & $4,57 \%$ & $5,55 \%$ & 0,67 & 0,67 & $4,04 \%$ & $9,27 \%$ \\
\hline Usiminas & $4,57 \%$ & $5,55 \%$ & 0,91 & 1,14 & $4,04 \%$ & $9,73 \%$ \\
\hline Vale Rio Doce & $4,57 \%$ & $5,55 \%$ & 0,93 & 1,21 & $4,04 \%$ & $9,80 \%$ \\
\hline Votorantim C P & $4,57 \%$ & $5,55 \%$ & 0,53 & 0,86 & $4,04 \%$ & $9,46 \%$ \\
\hline
\end{tabular}

\subsection{Definição operacional das variáveis}


Conforme foi justificado no referencial teórico, o modelo a ser adotado para a determinação do custo de capital próprio será o CAPM ajustado para o Brasil. A seguir serão descritos todos os procedimentos metodológicos utilizados nas variáveis desse modelo e, em seguida, será apresentado o modelo construído com objetivo de mensurar a transparência das empresas que compuseram a amostra desse estudo.

\subsubsection{Custo do capital próprio}

Para a determinação do custo do capital próprio, utilizou-se, nesse trabalho, o Modelo de Precificação de Ativos, ou Capital Asset Pricing Models - CAPM ajustado ao Brasil, conforme metodologia proposta por Assaf Neto (2003), que leva em consideração a existência de uma taxa livre de risco, um prêmio pelo risco de mercado e uma medida de risco da empresa, representado pelo coeficiente beta, de acordo com a expressão 7.

$$
K_{e}=\left[R_{F}+\beta \times\left(R_{M}-R_{F}\right)\right]+\alpha_{B R}
$$

Onde: $K_{e}=$ custo do capital próprio pelo método do CAPM

$$
\begin{aligned}
& R_{F}=\text { taxa de retorno de um ativo livre de risco } \\
& \beta=\text { coeficiente beta do título } \\
& R_{M}=\text { taxa de retorno da carteira de mercado } \\
& R_{M}-R_{F}=\text { prêmio pelo risco de mercado } \\
& \alpha_{B R}=\text { prêmio pelo risco-brasil }
\end{aligned}
$$

O CAPM é um modelo que considera a relação entre risco e retorno para a determinação do custo de oportunidade do capital próprio. Sua formulação indica que o retorno esperado de um título (ou outra aplicação) está positivamente relacionado a seu beta. A seguir, serão detalhados os componentes do Modelo de Precificação de Ativos, utilizados nesse trabalho.

Vale ressaltar mais uma vez que o modelo de determinação do custo do capital próprio proposto por Sanvicente e Minardi não foi utilizado basicamente por um motivo principal: a 
composição da carteira de ações utilizadas para a obtenção do retorno de mercado brasileiro, que não considera todas as empresas da Bovespa e sim ações de algumas empresas selecionadas por critérios não muito claros.

\section{- Taxa livre de risco}

Uma taxa considerada livre de risco (risk free) é aquela em que os investidores não incorrem nenhum risco ao aplicar seus recursos. Utilizou-se, nesse trabalho, como taxa livre de risco, a remuneração paga pelo governo americano sobre o seu título de maior liquidez, o T-Bond, considerado como o de mais baixo risco do mundo. O retorno do título americano no ano de 2005 foi de 4,57\% obtido no site do Instituto de Pesquisas Econômicas e Atuariais (IPEA).

\section{- Coeficiente beta}

Os coeficientes betas podem ser obtidos de fontes de publicação sobre as ações negociadas ativamente ou por meio de empresas de corretagem. Essas empresas baseiam seus cálculos na sensibilidade da ação ordinária da empresa em relação aos movimentos da carteira de mercado. Porém, essa metodologia de avaliação tem alguns pressupostos que dificultam sua aplicação no Brasil.

Uma primeira condição básica é que a quantidade de ações ordinárias em circulação seja condizente com o total emitido. Depois, a posse dessas ações não pode estar concentrada nas mãos de poucos investidores quando deveriam estar pulverizadas por todo o mercado. Se existir essas condições no mercado acionário, as ações ordinárias podem expressar com mais fidelidade o efetivo valor da empresa.

No mercado de capitais brasileiro, entretanto, essas condições não são observadas. O número de ações com direito a voto negociado em bolsa é muito reduzido em comparação ao total emitido e os papéis estão concentrados nas mãos de poucos investidores. Esse cenário compromete o cálculo do beta a partir das ações ordinárias, pois não reflete a realidade das empresas. 
Com base nisso, o coeficiente beta utilizado nesse trabalho seguiu a metodologia utilizada por Assaf Neto (2003, p. 87). O seu cálculo incluiu a obtenção de um beta não alavancado de uma economia utilizada como benchmark (nesse caso a americana) e depois procede-se a realavancagem do beta de acordo com a estrutura de financiamento e a alíquota de Imposto de Renda da empresa brasileira . Para isso, a seguinte expressão foi utilizada:

$$
\beta_{\mathrm{L}}=\beta_{\mathrm{U}} \times[1+(P / P L) \times(1-I R)]
$$

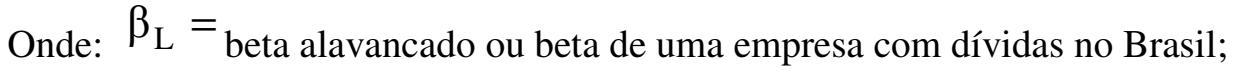

$\beta_{\mathrm{U}}={ }_{\text {beta não alavancado como benchmark; }}$

$\mathrm{P} / \mathrm{PL}=$ quociente de passivo oneroso sobre patrimônio líquido;

$\mathrm{IR}$ = alíquota do imposto de renda no Brasil;

Retorno Esperado de Mercado - Rm.

O Retorno esperado de mercado é calculado a partir do retorno médio das ações ordinárias das empresas de capital aberto negociadas livremente nas bolsas de valores e representada pela carteira de mercado. Nos Estados Unidos, os índices mais comumente utilizados são o da NYSE e o índice da Standard\&Poor's 500, composto pelas 500 ações mais negociadas nos EUA.

Assim sendo, adotou-se neste trabalho números do mercado acionário norte americano como benchmark para se estimar o custo de capital das empresas da amostra, como proposto por Assaf Neto (ibid., p. 85). O índice Standard \& Poor's 500 para o ano de 2005 foi de 5,55\%.

\section{- Prêmio pelo risco de mercado}

O prêmio pelo risco de mercado acionário, obtido pela diferença entre o retorno de mercado e a taxa livre de risco, também foi obtido por benchmark americano. O prêmio pelo risco de mercado utilizado nesse estudo foi $0,98 \%$,ou seja, $5,55 \%$ do retorno de mercado menos $4,57 \%$ do risk free (T-Bond). 
Cabe ressaltar que esse baixo prêmio pelo risco de mercado americano, já que ainda não adicionou-se o risco Brasil, deve-se basicamente pelo baixo retorno do índice S\&P 500, pois 2005 foi um ano onde o mercado acionário americano apresentou um de seus menores retornos quando comparado com a série histórica das bolsas. Isso vai refletir em um custo de capital próprio menor, quando comparado com alguns anos recentes.

\section{- Prêmio pelo Risco-Brasil}

O risco país reflete a capacidade de uma nação em honrar seus compromissos externos. Quanto maior for a desconfiança dos investidores em relação ao país, maior será a remuneração exigida pelos investidores no empréstimo de seu dinheiro. Esse risco é medido pela diferença entre os juros pagos pelos papéis da dívida externa de determinado país e a taxa oferecida por um título livre de risco, geralmente o T-Bond (Treasury Bond) emitido pelo governo americano.

O principal título de dívida pública brasileira é o C-Bond (Capitalization Bond), negociado livremente no mercado internacional e considerado como o de maior liquidez. Quando o valor desse título se valoriza no mercado, demonstra um maior grau de confiança dos investidores com relação à capacidade brasileira de cumprir seus compromissos financeiros.

No entanto, o C-Bond parou de ser negociado em outubro de 2005, quando o Governo brasileiro resgatou todos esses títulos da sua dívida. Como esse estudo tem como base o ano de 2005, utilizou-se o título brasileiro mais líquido após o C-Bond, o Global 40. Em 2005, o Global 40 registrou um retorno de 4,04\% capitalizado mês a mês. Esse valor foi utilizado como proxy do risco-país no cálculo do custo do capital próprio pela metodologia do CAPM ajustado.

\subsubsection{Transparência}

Como dito anteriormente, o nível de transparência de uma companhia não é um fator diretamente observável, sendo necessário, para isso, a construção de algum modelo que 
possibilite essa observação. Neste trabalho, a variável transparência foi determinada por meio da construção de um questionário composto de 14 questões (descritas abaixo) que foram respondidas a partir da consulta dos sites das empresas da amostra.

Para que se chegasse à esse questionário, foram utilizados dois questionários elaborados por outros pesquisadores que estudaram esse tema anteriormente além da elaboração de algumas perguntas específicas mais adequadas aos objetivos desta dissertação. Assim sendo, as nove primeiras questões listadas abaixo e a última questão foram extraídas do questionário de Silveira (2004, p. 217). Já as questões de n. 10 e n. ${ }^{\circ} 11$ foram extraídas de um questionário elaborado por Alencar e Lopes (2005, p. 6). Por fim, as questões de n. ${ }^{\circ} 12$, n. $^{\circ} 13$ e n. ${ }^{\circ} 14$ foram incluídas no questionário por serem consideradas importantes na verificação no nível de transparência das empresas analisadas deste estudo especificamente.

As questões de Silveira (2004) buscam levantar elementos sobre transparência obteníveis nos sites das empresas, o que apresenta dois pontos positivos: viabiliza a pesquisa e é um veículo de acesso facilitado para qualquer investidor em potencial ou outro grupo de interesse. As questões de Alencar e Lopes (2005) remetem à qualidade da informação em demonstrações contábeis.

Com relação ainda às questões 10 e 11, foram elaboradas com objetivo de verificar se a empresa foi indicada e/ou vencedora do prêmio ANEFAC, uma das medidas de disclosure existente atualmente no Brasil. A ANEFAC surgiu em 1976 a partir da necessidade de se gerar intercâmbio entre executivos da área de finanças. Ao longo dos anos a ANEFAC vem se firmando com entidade representativa dos profissionais de finanças, administração e contabilidade, respeitada nos meios públicos e privados, pelo seu posicionamento firme e claro em relação aos problemas macroeconômicos bem como na defesa e esclarecimento dos problemas enfrentados pelo consumidor.

Através de uma premiação anual, a ANEFAC procura incentivar a transparência nas demonstrações contábeis e no aprimoramento dos profissionais das diversas áreas. Todos os benefícios que as empresas obtêm ao adotar uma postura de favorecimento a uma maior evidenciação contábil-financeira, sugeridos pela literatura apresentada anteriormente, serão dinamizados a partir do reconhecimento público dessas ações. Nesse sentido, o Prêmio 
Transparência da ANEFAC exerce um papel de fundamental importância, uma vez que os investidores conheçam as empresas mais comprometidas com a boa evidenciação.

O Prêmio da ANEFAC é um reconhecimento público da melhor demonstração contábil publicada no país. Criado em 1997, em parceria com a FIPECAFI (Fundação Instituto de Pesquisas Contábeis, Atuariais e Financeiras) e a Serasa, tem o objetivo de incentivar a transparência corporativa no mercado, por meio do fornecimento de informações claras e de qualidade.

A premiação é dividia em duas categorias:

- Categoria Empresas Abertas - 10 Mais Transparentes;

- Categoria Empresas Fechadas - 5 Destaques Transparência.

Concorrem ao prêmio empresas sediadas em todo o território nacional, selecionadas entre as 500 maiores e melhores empresas do Brasil nas áreas de Comércio, Indústria e Serviços, exceto serviços financeiros. Devem obrigatoriamente divulgar as seguintes demonstrações:

- Balanço patrimonial;

- Demonstração do resultado do exercício;

- Demonstrações das mutações do patrimônio líquido;

- Demonstração das origens e aplicações de recursos;

- Notas explicativas;

- Demonstrações comparativas;

- Relatório da administração;

- $\quad$ Parecer dos auditores independentes.

Não há restrições quanto ao formato jurídico da empresa, podendo ela ser uma sociedade anônima de capital aberto, fechado, sociedade por quotas, etc. Também não há restrições quanto aos resultados e situação econômico-financeira das empresas, os quais não interferem no processo de seleção. Os critérios de seleção são:

- Qualidade e grau das informações contidas nas demonstrações e notas explicativas; 
- Transparência das informações prestadas;

- Qualidade do relatório da administração e sua consistência com as informações divulgadas;

- Aderência aos Princípios Contábeis;

- Ressalvas no parecer dos auditores independentes, levando-se em conta suas naturezas;

- $\quad$ Apresentação da divulgação quanto ao layout, legibilidade, concisão, clareza etc.;

- Divulgação de aspectos relevantes, não exigidos legalmente, mas importantes para o negócio como: fluxo de caixa, demonstração do valor adicionado, valor econômico agregado, balanço social, efeitos inflacionários e outros.

O processo de julgamento é feito em três fases. Na primeira fase, alunos dos cursos de Mestrado e Doutorado em Controladoria e Contabilidade da Faculdade de Economia, Administração e Contabilidade da Universidade de São Paulo (FEA/USP) selecionam as demonstrações que melhor atendem os critérios, para encaminhamento à comissão julgadora.

Na segunda fase são selecionadas as melhores demonstrações, pela comissão julgadora, assim composta por professores da FEA/USP, representantes da FIPECAFI e o presidente da ANEFAC. A terceira fase ocorre no próprio dia da festa de premiação onde é eleita uma empresa de cada categoria vencedora do Troféu Transparência, Prêmio ANEFAC FIPECAFI - Serasa.

Portanto, as 14 questões que buscaram quantificar o nível de transparência das empresas da amostra são as seguintes:

- Questão 1 - É possível obter o Relatório Anual (RA) da companhia via internet?

- Questão 2 - O website dispõe de documentos relativos à governança corporativa, tais como: explicações do modelo de governança da companhia, código de boas práticas de governança corporativa da empresa, regimento interno do conselho de administração ou política de negociação de valores mobiliários?

- Questão 3 - O website dispõe de apresentações para analistas ou dados que possibilitem projeções operacionais e financeiras da empresa? 
- Questão 4 - O website é bilíngüe e possui uma seção de Relação com os Investidores?

- Questão 5 - O relatório anual inclui uma seção específica dedicada à implementação de princípios de governança corporativa?

- Questão 6 - O relatório anual, website ou relatório 20-F explica a remuneração global dos executivos?

- Questão 7 - Os demonstrativos são apresentados em US-GAAP ou IAS-GAAP?

- Questão 8 - O relatório anual, website ou algum outro documento inclui uma seção com estimativas de lucros ou projeções de retornos financeiros (ROA, ROE etc.)?

- Questão 9 - O relatório anual, website ou algum outro documento corporativo apresenta o valor adicionado/destruído pelo negócio no período com base em alguma medida de econômico?

- Questão 10 - A empresa foi indicada ao prêmio Transparência da ANEFAC.

- Questão 11 - A empresa foi ganhadora do prêmio Transparência da ANEFAC.

- Questão 12 - A empresa aderiu aos níveis diferenciados de governança corporativa da BOVESPA (níveis 1 e 2 e novo mercado).

- Questão 13 - A empresa emitiu ADR (internacionalização).

- Questão 14 - Não houve necessidade de contato direto com representante da companhia para obtenção de informações sobre a empresa.

Para responder cada uma dessas questões, foram consultados os sites das empresas da amostra e foram atribuídos pontos para cada pergunta. As respostas poderiam ser SIM (atribuição de 1 ponto) ou NÃO (sem atribuição de ponto). Portanto, uma empresa poderia totalizar no 
máximo 14 pontos, sendo esta empresa considerada uma companhia totalmente transparente. De outra forma, a empresa poderia totalizar zero ponto, caso todas as questões acima fossem respondidas com $\mathrm{NÃO}$, fazendo com que a empresa fosse considerada como totalmente não transparente.

\subsection{Variáveis de controle}

As variáveis de controle, usadas com o objetivo de isolar sua influência sobre o relacionamento entre as variáveis mencionadas anteriormente, foram as sugeridas por Alencar e Lopes $(2005$, p. 6) e são as seguintes:

\subsubsection{Tamanho da empresa}

A variável de controle tamanho da empresa será representada pela Receita Bruta de Vendas mo período de 01 de janeiro a 31 de dezembro de 2005, obtida na Demonstração de Resultado do Exercício, disponibilizada no banco de dados Economática ${ }^{\circledR}$. Essa variável de controle se faz necessária porque a literatura aponta que empresas maiores tendem a captar recursos com um custo menor. Por isso, espera-se que o tamanho da empresa seja negativamente correlacionado com o custo de capital próprio.

Como a receita bruta é muito diferente para as empresas da amostra, utilizou-se o logaritmo neperiano da receita bruta para que se pudesse correlacionar empresas de tamanhos muito diferentes, conforme aconselhado para estudos dessa natureza que trabalham com variáveis de alto grau de amplitude. Vale ressaltar que este trabalho optou por utilizar a receita bruta de vendas (ao invés por exemplo da utilização do Ativo Total ou do valor do Patrimônio Líquido) para determinação das maiores empresas seguindo o que é geralmente utilizado em estudos acadêmicos com essa finalidade.

\subsubsection{Grau de endividamento}


O grau de endividamento é a relação entre o Exigível Total e o Patrimônio Líquido. Neste estudo o grau de endividamento das empresas da amostra foi calculado a partir dos dados extraídos das demonstrações contábeis das empresas da amostra, disponibilizadas no software Economática ${ }^{\circledR}$. Os valores estão expressos em porcentagem, referem-se a demonstrações consolidadas em 31 de dezembro de 2005.

\subsubsection{Relação entre preço da ação e valor patrimonial}

A relação entre o preço da ação e o valor patrimonial da empresa indica o grau de conservadorismo dos números contábeis em relação à avaliação do mercado. Esse indicador também é conhecido como índice book-to-market e é obtido mediante a expressão 9.

$$
\text { Preço/Valor Patrimonial }=\frac{\text { Cotação da ação }(\text { valor de mercado })}{\text { Patrimônio Líquido por ação }(\text { valor contábil })}
$$

Deve ressaltar que, para algumas empresas com um grande valor de ativos intangíveis não registrados nas demonstrações contábeis, o fato de um alto goodwill não contabilizado pode explicar em parte essa variável. Porém, mesmo levando em consideração esse fator, essa variável de controle será utilizada, seguindo o mesmo procedimento adotado em estudos semelhantes a este.

Neste estudo relação entre o preço da ação e o valor patrimonial das empresas da amostra foi coletado no software Economática ${ }^{\circledR}$, os dados são em moeda original, são consolidados, no exercício de dezembro de 2005.

Os resultados do cálculo dessas variáveis estão apresentadas na tabela 2. 
Tabela 2 - Variáveis a serem correlacionadas no modelo de regressão

$\begin{array}{lccccc}\text { Empresa } & \begin{array}{c}\text { Custo do } \\ \text { Capital } \\ \text { Próprio }\end{array} & \begin{array}{c}\text { Transpa- } \\ \text { rência }\end{array} & \begin{array}{c}\text { LogN } \\ \text { Receita } \\ \text { Bruta }\end{array} & \begin{array}{c}\text { Endivida- } \\ \text { mento } \\ \text { (P/PL) }\end{array} & \begin{array}{c}\text { Índice } \\ \text { Book-to- } \\ \text { market }\end{array} \\ \text { Acesita } & 9,71 \% & 6 & 14,90 & 0,35 & 0,92 \\ \text { Ambev } & 9,29 \% & 12 & 16,93 & 0,36 & 2,95 \\ \text { Aracruz } & 9,46 \% & 10 & 14,97 & 0,96 & 2,31 \\ \text { Brasil T Par } & 9,63 \% & 10 & 16,38 & 0,21 & 1,57 \\ \text { Brasil Telecom } & 10,41 \% & 11 & 16,22 & 0,64 & 1,19 \\ \text { Braskem } & 10,61 \% & 12 & 16,22 & 0,88 & 0,99 \\ \text { Caemi } & 9,96 \% & 8 & 16,35 & 1,13 & 1,46 \\ \text { Celesc } & 9,63 \% & 3 & 13,99 & 0,17 & 5,23 \\ \text { Cemig } & 9,36 \% & 1 & 15,06 & 0,21 & 1,04 \\ \text { Cesp } & 9,57 \% & 11 & 16,09 & 0,69 & 2,14 \\ \text { Comgas } & 9,75 \% & 8 & 14,36 & 1,12 & 0,20 \\ \text { Copel } & 9,36 \% & 5 & 14,84 & 0,93 & 3,44 \\ \text { CRT Celular } & 9,43 \% & 12 & 15,52 & 0,36 & 0,85 \\ \text { Eletrobras } & 9,98 \% & 0 & 14,33 & 0,12 & 1,62 \\ \text { Eletropaulo Metropo } & 9,43 \% & 8 & 15,32 & 0,36 & 0,37 \\ \text { Embraer } & 9,87 \% & 8 & 15,94 & 1,38 & 2,14 \\ \text { Embratel Part } & 10,00 \% & 13 & 15,61 & 0,74 & 3,50 \\ \text { Gerdau } & 10,05 \% & 9 & 15,93 & 0,21 & 0,91 \\ \text { Gerdau Met } & 9,95 \% & 11 & 16,84 & 0,75 & 2,16 \\ \text { Ipiranga Pet } & 9,92 \% & 8 & 16,84 & 0,71 & 1,55 \\ \text { Itausa } & 9,70 \% & 6 & 16,64 & 0,42 & 1,13 \\ \text { Klabin } & 8,98 \% & 9 & 16,03 & 0,03 & 2,41 \\ \text { Light } & 9,39 \% & 7 & 14,70 & 0,76 & 1,70 \\ \text { Net } & 10,15 \% & 2 & 15,60 & 2,04 & 1,21 \\ \text { Petrobras } & 10,86 \% & 8 & 14,40 & 1,27 & 6,81 \\ \text { Sabesp } & 9,42 \% & 12 & 18,84 & 0,53 & 2,04 \\ \text { Sadia } & 9,34 \% & 10 & 15,29 & 0,79 & 0,53 \\ \text { Sid Nacional } & 9,59 \% & 9 & 15,54 & 1,39 & 1,97 \\ \text { Souza Cruz } & 10,30 \% & 8 & 15,90 & 1,36 & 2,01 \\ \text { Tele Centroeste Cel } & 9,44 \% & 7 & 15,66 & 0,61 & 5,37 \\ \text { Tele Leste Celular } & 9,91 \% & 7 & 14,97 & 0,04 & 1,24 \\ \text { Telemar Norte Leste } & 10,88 \% & 2 & 13,63 & 1,21 & 1,27 \\ \text { Telemig Celul Part } & 10,41 \% & & 16,70 & 0,64 & 1,41 \\ \text { Telemar-Tele NL Par } & 10,04 \% & & 14,04 & 0,20 & 1,55 \\ \text { Telesp } & 10,70 \% & 10 & 16,70 & 0,99 & 1,99 \\ \text { Tim Participacoes } & 10,07 \% & 9 & 16,55 & 0,23 & 2,27 \\ \text { Transmissao Paulist } & 9,92 \% & 2 & 16,10 & 0,05 & 1,89 \\ \text { Usiminas } & 9,27 \% & 9 & 13,86 & 0,00 & 1,03 \\ \text { Vale Rio Doce } & 9,73 \% & 7 & 16,31 & 0,39 & 1,36 \\ \text { Votorantim C P } & 9,80 \% & 12 & 17,22 & 0,46 & 4,01 \\ & 9,46 \% & 7 & 14,97 & 0,95 & 1,33\end{array}$




\section{ANÁLISE DOS RESULTADOS DA PESQUISA}

\subsection{Estatística descritiva}

Com base nas variáveis obtidas conforme metodologia explicada anteriormente, cujos resultados estão expressos na tabela 2, procedeu-se aos cálculos da estatística descritiva das variáveis desse estudo, conforme mostra a tabela 3.

Tabela 3 - Resultado da Estatística Descritiva

\begin{tabular}{lccccc} 
& N & Mínimo & Máximo & Média & Desvio-padrão \\
\hline Custo de Capital Próprio (Ke - y0) & 41 & $8,98 \%$ & $10,88 \%$ & $9,82 \%$ & $0,45 \%$ \\
Transparência (Trnsp - y1) & 41 & 0 & 13,0 & 8,0 & 3,3 \\
Tamanho (Tam - y2) & 41 & 13,6 & 18,8 & 15,7 & 1,1 \\
Endividamento (Endiv - y3) & 41 & 0,003 & 2,038 & 0,651 & 0,460 \\
Preço/valor patrimonial (BTM -y4) & 41 & 0,20 & 6,81 & 1,98 & 1,37 \\
\hline
\end{tabular}

\subsection{Análise da correlação de Pearson}

De posse das informações relativas ao Custo de Capital Próprio, Transparência, Tamanho da Empresa, Endividamento e Índice Book-to-Market, foi realizado um estudo comparativo com o objetivo de verificar se existe uma relação entre essas variáveis. E, se existe, se a correlação é positiva ou negativa. Isso será feito antes de se aplicar o modelo de regressão linear múltipla para testar a relação de causa-efeito entre as variáveis Transparência e Custo de Capital Próprio (item 3.4)

Para Triola (2005, p. 381), o estudo da correlação é usado para determinar se existe uma relação estatisticamente significante entre duas variáveis e pode ser estudado por meio do coeficiente de correlação linear, que mede a direção e a intensidade da associação linear entre dados amostrais emparelhados. A fórmula do coeficiente de correlação linear (r), também chamado de coeficiente de correlação de produto de momentos de Pearson, é a seguinte:

$$
r=\frac{n \sum x y-\left(\sum x\right)\left(\sum y\right)}{\sqrt{n\left(\sum x^{2}\right)-\left(\sum x\right)^{2}} \cdot \sqrt{n\left(\sum y^{2}\right)-\left(\sum y\right)^{2}}}
$$


Onde: $r=$ coeficiente de correlação linear;

$n=$ número de pares de dados presentes;

$\Sigma=$ soma dos itens indicados;

$x=$ variáveis $\mathrm{x}$;

$y=$ variáveis $y$.

Neste estudo, as variáveis serão primeiramente correlacionadas uma a uma e, depois, correlacionadas em conjunto, no estudo da regressão múltipla. Vale ressaltar que a determinação da ordem das variáveis não altera o resultado do coeficiente de correlação. De acordo com Triola (2005, p. 385), o valor de r deve sempre estar entre -1 e +1 , inclusive. Se r estiver muito próximo de 0 , conclui-se que não há correlação linear significante entre as variáveis em estudo, mas, se $\mathrm{r}$ estiver próximo de -1 ou +1 , pode-se concluir que existe uma relação linear significativa entre as variáveis analisadas.

Tabela 4 - Resultado da correlação

\begin{tabular}{lccccc} 
& Ke (y0) & Trnsp (y1) & Tam (y2) & Endiv (y3) & BTM (y4) \\
\hline Custo de Capital Próprio (Ke-y0) & 1,0000 & - & - & - & - \\
Transparência (Trnsp-y1) & $-0,05739$ & 1,0000 & - & - & - \\
Tamanho (Tam-y2) & $-0,01404$ & 0,527427 & 1,0000 & - & - \\
Endividamento (Endiv-y3) & 0,386594 & 0,004957 & $-0,0209$ & 1,0000 & - \\
Preço/valor patrimonial (BTM-y4) & 0,085842 & 0,033165 & $-0,02546$ & 0,074969 & 1,0000 \\
\hline
\end{tabular}

Como pode ser verificado na tabela 4 , as variáveis que estão mais significativamente correlacionadas positivamente são o Tamanho da Empresa e a Transparência. Isso mostra que empresas maiores são aquelas que mais evidenciam informações segundo o modelo utilizado para medir transparência desse estudo. O questionário analisou, entre outros aspectos, disponibilidade de obtenção do Relatório Anual da na internet, disposição de documentos relativos à governança corporativa, apresentações de dados no site que possibilitassem projeções operacionais e financeiras da empresa por analistas, adesão aos níveis diferenciados de governança corporativa e outros.

Segundo Tapscott e Ticoll (2005, p. 41), a transparência exige investimentos em novas funções organizacionais para fins de acompanhamento de relatórios, interações com os stakeholders e auditorias externas. Para empresas pequenas ou com baixas margens de lucro, 
tais despesas podem ser praticamente proibitivas. Esse fator explica o motivo pelo qual o tamanho da empresa está altamente relacionado com o grau de transparência das organizações.

Outras duas variáveis com maior correlação positiva foram o Custo do Capital Próprio e Endividamento. Isso também era esperado, uma vez que a literatura de finanças, por meio dos modelos de risco e retorno, suporta a teoria de que, quanto maior o grau de endividamento de uma empresa, maior o seu risco e, conseqüentemente, maior o custo do capital exigido pelos acionistas.

Outro aspecto relevante a ser ressaltado é a correlação negativa entre Custo de Capital Próprio e a proxy adotada para Transparência. Apesar da baixa correlação apresentada, o fato de essas duas variáveis estarem negativamente correlacionadas era esperada, já que a teoria afirma que quanto maior o nível de transparência de uma empresa, menor a estimativa do custo de capital exigido pelos acionistas.

\subsection{Teste de hipóteses para correlação}

Para verificar se as correlações obtidas entre as variáveis desse estudo, conforme mostrada na tabela 4, foram estatisticamente significativas, procedeu-se a um teste formal de hipóteses. A metodologia foi extraída de Triola (2005, p. 387). A hipótese nula (H0) é de que a correlação $(\rho)$ entre as variáveis testadas duas a duas é zero, ou seja, não existe correlação significativa entre as relacionadas. A hipótese alternativa (H1) é de que existe correlação linear significante entre as variáveis. Vale ressaltar que esse teste será feito apenas para verificar se as correlações obtidas foram significativas.

$$
\begin{aligned}
& H_{0}: \rho=0 \text { (Não há correlação linear entre as variáveis) } \\
& H_{1}: \rho \neq 0 \text { (Há uma correlação linear entre as variáveis) }
\end{aligned}
$$

A estatística de teste (t) é a seguinte: 


$$
t=\frac{r}{\sqrt{\frac{1-r^{2}}{n-2}}}
$$

Onde: $\mathrm{t}=$ Valor da estatística de teste

$\mathrm{r}=$ Coeficiente de Correlação

$\mathrm{n}=$ Número de observações da amostra

Aplicando a estatística de teste nos coeficientes de correlação da tabela 5, obtêm-se os resultados mostrados na tabela 5. O valor crítico de $\mathrm{t}$ foi determinado para $\mathrm{n}-2$ graus de liberdade, a partir da distribuição $t$ de Student com área em duas caudas e intervalo de confiança de $95 \%(\alpha=0,05$ ) e é de 2,024 .

Tabela 5 - Estatística de teste para a correlação de Pearson

\begin{tabular}{lccccc} 
& Ke (y0) & Trnsp (y1) & Tam (y2) & Endiv (y3) & BTM (y4) \\
\hline Custo de Capital Próprio (Ke-y0) & 1,0000 & - & - & - & - \\
Transparência (Trnsp-y1) & $-0,35897$ & 1,0000 & - & - & - \\
Tamanho (Tam-y2) & $-0,08768$ & 3,876862 & 1,0000 & - & - \\
Endividamento (Endiv-y3) & 2,617816 & 0,030954 & $-0,13053$ & 1,0000 & - \\
Preço/valor patrimonial (BTM-y4) & 0,538069 & 0,207232 & $-0,15906$ & 0,469501 & 1,0000 \\
\hline
\end{tabular}

A tabela 5 mostra que o valor da estatística de teste excede o valor crítico de t $(2,024)$ para a correlação entre as variáveis Custo de Capital Próprio (Ke) x Endividamento (Endiv) e Transparência (Trnsp) x Tamanho da empresa (Tam). Isso faz com que se rejeite a hipótese nula de que a correlação entre essas variáveis é igual a zero. Como (H0) é rejeitada, existem evidências empíricas amostrais suficientes para apoiar a afirmativa de que há uma correlação linear positiva estatisticamente significativa entre o Custo de Capital Próprio e Endividamento assim como entre Transparência e Tamanho da Empresa.

Já a estatística de teste para a correlação entre as variáveis Custo de Capital Próprio (Ke) e Transparência (Trnsp) de -0,35897, faz com que deixe-se de rejeitar a hipótese nula de que a correlação entre essas variáveis é igual a zero. Como (H0) não é rejeitada, não existem evidências empíricas amostrais suficientes para apoiar a afirmativa de que há uma correlação linear positiva estatisticamente significativa entre o Custo de Capital Próprio e Transparência. 
No entanto, o coeficiente de correlação de Pearson não mede a relação de causa-efeito entre as variáveis relacionadas, mesmo que ela esteja presente. O coeficiente de correlação de Pearson indica apenas a força da correlação entre as variáveis (forte ou fraca) e o sentido da correlação (negativa ou positiva). Isso não nos dá subsídio para afirmar, por exemplo, que um aumento do endividamento da empresa implique necessariamente em uma aumento do Custo de Capital Próprio da empresa ou que, quanto maior a empresa, maior o grau de transparência. Para isso, será feito o estudo da Regressão Linear Múltipla, logo após o teste de normalidade de Kolmogorov-Smirnov.

\subsection{Análise dos resultados da regressão linear múltipla}

O modelo de regressão linear permite testar a relação de causa-efeito entre as variáveis. Para isso, deve-se definir de início a variável dependente e as variáveis independentes. Nesse estudo, a variável dependente (ou variável resposta) é o Custo de Capital Próprio (Ke) e as demais variáveis são todas independentes ou preditoras.

Para testar a relação entre transparência (TRNSP) e custo de capital próprio (KE) no mercado brasileiro, considerando como variáveis de controle tamanho da empresa (TAM), grau de endividamento (ENDIV) e índice book-to-market (BTM), foi utilizado o seguinte modelo:

$$
\hat{\gamma} \cdot K E=b_{0}+b_{1} T R N S P+b_{2} T A M+b_{3} E N D I V+b_{4} B T M
$$

O modelo de regressão, extraído de Triola (2005, p. 397), mostra que $b_{0}, b_{1}, b_{2}$ e $b_{3}$ são estatísticas amostrais usadas para estimar os parâmetros populacionais $\beta_{0}, \beta_{1}, \beta_{2}, \beta_{3}$ e $\beta_{4}$. Serão utilizados dados amostrais emparelhados para estimar a equação de regressão, por meio das seguintes expressões de cálculo:

$$
\begin{aligned}
& b_{1}, b_{2}, b_{3}, b_{4}=\frac{n\left(\sum x y\right)-\left(\sum x\right)\left(\sum y\right)}{n\left(\sum x^{2}\right)-\left(\sum x\right)^{2}} \\
& b_{0}=\frac{\left(\sum y\right)\left(\sum x^{2}\right)-\left(\sum x\right)\left(\sum x y\right)}{n\left(\sum x^{2}\right)-\left(\sum x\right)^{2}}
\end{aligned}
$$


Os coeficientes $b_{1}, b_{2}, b_{3}$ e $b_{4}$ indicam a declividade da reta e definem o aumento ou a diminuição da variável ${ }^{\hat{y}}$. A constante $b_{0}$ é o intercepto de ${ }^{y}$, sendo igual ao valor de $\hat{y}_{\text {para }}$ $x=0$

A regressão foi efetuada utilizando-se como variável dependente o Custo do Capital Próprio (Ke) e como variáveis independentes a proxy para transparência, o tamanho da empresa, o grau de endividamento e o índice book-to-market. O mesmo resultado seria obtido caso fosse utilizado um software estatístico, tal como o SPSS ${ }^{\circledR}$. Por conveniência, optou-se por utilizar o Excel ®. O primeiro output de saída do Excel ® é mostrado na tabela 6

\begin{tabular}{cc} 
Tabela 6 - Estatística de Regressão para o modelo utili \\
\hline R múltiplo & 0,39689378 \\
R-Quadrado & 0,157524672 \\
R-quadrado ajustado & 0,063916303 \\
Erro padrão & 0,004376933 \\
Observações & 41 \\
\hline
\end{tabular}

O R-múltiplo indica o coeficiente de correlação do modelo de regressão, que nesse caso foi de 0,3969, indicando que as variáveis do modelo são positivamente correlacionadas. O RQuadrado ou $R^{2}$ é o coeficiente de determinação do modelo de regressão e mede o grau de ajustamento da reta de regressão aos dados observados. De acordo com Corrar e Theóphilo (2004, p.92) o $R^{2}$ indica a proporção da variação total da variável dependente que é explicada pela variação da variável independente. Nesse estudo, a análise do R-Quadrado mostra que 15,75\% da variação do custo do capital deve-se às variações das variáveis independentes utilizadas no modelo de regressão.

Como a correlação entre as variáveis independentes (ou exógenas) foram tratadas de maneira bivariadas e a análise dessa correlação mostrou que nem todas são altamente correlacionadas entre si, conforme tabela 4 , pode-se pressupor que o alto valor de $R^{2}$ apontado no modelo de regressão não deve-se à multicolinearidade.

O R-Quadrado ajustado ou $\bar{r}^{2}$, de acordo com Lapponi (2005, p. 413), mostra a porcentagem de explicação caso se partisse de um modelo de regressão simples, com uma única variável independente. Nesse caso, o poder de explicação do modelo de regressão seria de 6,39\% (ou 
0,063916303 conforme a tabela 6). Ao aumentarem-se posteriormente mais variáveis independentes, o valor do R-Quadrado ( $R^{2}$ ) não diminuiria e, no nosso caso, aumentaria.

O erro padrão ou $S_{e}$ mostra que aproximadamente $95 \%$ das observações de ${ }^{y}$ devem encontrar-se dentro do intervalo de mais ou menos dois erros-padrão. Nesse estudo, significa dizer que 95\% do Custo do Capital Próprio (Ke) da amostra deve-se encontrar a $\pm 2 S_{e}$ dos seus respectivos valores projetados $\hat{y}_{\text {da }}$ reta de regressão. Por fim, a última informação apresentada na tabela 6 refere-se ao número de observações da amostra, que nesse estudo foi de 41 empresas.

Tabela 7 - Grupo ANOVA de resultados

\begin{tabular}{lllccc}
\hline & gl & \multicolumn{1}{c}{ SQ } & MQ & F & F de significação \\
\hline Regressão & 4 & 0,000128954 & $3,22384 \mathrm{E}-05$ & 1,682805425 & 0,175325505 \\
Resíduo & 36 & 0,000689672 & $1,91575 \mathrm{E}-05$ & & \\
Total & 40 & 0,000818625 & & & \\
\hline
\end{tabular}

A coluna gl apresenta os graus de liberdade, para 4 variáveis independentes, gl do resíduo de 36 e n-1 empresas na amostra $(41-1=40)$. A coluna SQ indica a soma dos quadrados das variações explicadas pela regressão, pelos resíduos e a soma dos quadrados totais, uma vez que o modelo de regressão adotado foi a dos mínimos quadrados, onde a reta de regressão tende a garantir que a distância vertical total entre os pontos acima da reta fossem igual à dos pontos abaixo da reta, de acordo com Lapponi (2005).

A coluna MQ mostra o resultado da divisão do valor do SQ pelo correspondente número de graus de liberdade da coluna $g l$. O valor de F mostra a variância explicada pela variância não explicada e pode ser obtido pela divisão do MQ da linha Regressão pelo MQ da linha Resíduo, que resulta em 0,1753 .

O F de Significação é o valor p (ou p-value) para o teste de hipóteses. Como o p-value é maior que o nível de significância de $5 \%$ e intervalo de confiança de $95 \%$, impede que a regressão seja aceita como estatisticamente significativa. Isso faz com que a a hipótese principal do trabalho seja rejeitada. 
Tabela 8 - Demais resultados do modelo de regressão

\begin{tabular}{lcccc} 
& Coeficientes & Erro padrão & Stat t & valor-P \\
\hline Interseção & 0,093754544 & 0,011202363 & 8,369175537 & $5,75302 \mathrm{E}-10$ \\
Trnsp (y1) & $-0,000113205$ & 0,000250036 & $-0,45275685$ & 0,653440742 \\
Tam (y2) & 0,000163298 & 0,000763219 & 0,213959707 & 0,831785728 \\
Endiv (y3) & 0,003725781 & 0,001491818 & 2,497476458 & 0,017217567 \\
BTM (y4) & 0,00020131 & 0,00050881 & 0,395648121 & 0,694699659 \\
\hline
\end{tabular}

A tabela 8 apresenta os demais resultados do modelo de regressão, a saber, os coeficientes das variáveis independentes, onde o intercepto diferente de zero mostra que a regressão não passa pela origem do plano cartesiano. $\mathrm{O}$ erro padrão indica, aproximadamente, quão distante o coeficiente amostral está do coeficiente da população, devido à variabilidade amostral.

A coluna Stat $t$, representa a estatística de um teste formal de hipóteses para verificar a relação entre as variáveis. Quando analisada em comparação ao valor-P - que permite maior poder de afirmação da relação entre as variáveis da regressão quanto menor o valor dessa estatística observa-se que as variáveis não apresentam correlação estatisticamente significativa para um intervalo de confiança de $95 \%$, exceto para a variável endividamento, que mostra correlação significativa com a variável dependente Custo de Capital Próprio, o que corrobora o resultado obtido na análise da correlação de Pearson.

\subsection{Teste de normalidade Kolmogorov-Smirnov}

Para Corrar e Theóphilo (2004, p. 107), os testes de significância e os intervalos de confiança das estimativas dos modelos de regressão baseiam-se no pressuposto da normalidade. Dessa forma, a verificação da normalidade da distribuição dos resíduos torna-se fundamental para garantir a eficiência das estimativas obtidas pelo Método dos Mínimos Quadrados.

Para avaliação da normalidade, será utilizado o teste de Kolmogorov-Smirnov, cuja estatística de teste é a seguinte:

$$
D=\text { máx. }\left|\frac{\mathrm{i}}{\mathrm{n}}-z_{1}\right|
$$

Onde: $\mathrm{n}=$ tamanho da amostra, sendo $\mathrm{i}=1,2,3, \ldots, \mathrm{n}$; 
$z_{i}=$ probabilidade acumulada da distribuição normal padronizada,

considerando os valores $h_{i}=\frac{u_{i}}{s}$, onde $u_{i}$ são os resíduos ordenados de forma crescente e $s$ é o desvio-padrão dos $u_{i}$.

Procedendo-se ao cálculo da estatística de teste, conforme expressão 17, obtém-se 0,11564289. O valor crítico ( Dcrítico ) para um nível de significância $\alpha$ de 5\% - intervalo de confiança de $95 \%$-, tamanho da amostra de 41 observações é de aproximadamente 0,21. Como a estatística de teste $(0,11564289)$ é menor que o valor crítico $(0,21)$, deixa-se de rejeitar a hipótese nula de que os resíduos se distribuem normalmente.

Isso nos fornece evidências de que os resíduos das variáveis independentes utilizadas no modelo de regressão deste estudo seguem uma distribuição normal de probabilidade, o que permite utilizar o Método dos Mínimos Quadrados. Portanto, a não violação da normalidade, mostra que variáveis explicativas importantes na explicação do custo do capital próprio não foram omitidas.

\subsection{Teste de Multicolinearidade de Farrar e Glauber}

O problema da multicolinearidade surge quando as variáveis explicativas possuem uma alta correlação entre si. Para Corrar e Theóphilo (2004, p. 116), quando as variáveis explicativas são multicolineares, elas fornecerão informações similares para explicar e prever o comportamento da variável dependente. Isso dificulta a separação do efeito que cada uma das variáveis exerce sobre a variável dependente, prejudicando a habilidade preditiva do modelo de regressão.

O maior cuidado com esse problema se dá principalmente em modelos de regressão que apresentam um alto coeficiente de determinação ajustado e que, no entanto, todas as estimativas do modelo não são estatisticamente significativas. Isso não acontece neste trabalho, uma vez que o coeficiente de determinação ajustado $\left(R^{2}\right)$ foi baixo $(15,75 \%)$ e a regressão não apresentou significância estatística. 
Para detectar a presença de multicolinearidade, primeiramente calculou-se o coeficiente de correlação entre as variáveis independentes de forma bivariada e os resultados estão na tabela 9.

Tabela 9 - Correlação entre as variáveis independentes

\begin{tabular}{lccccc} 
& Ke (y0) & Trnsp (y1) & Tam (y2) & Endiv (y3) & BTM (y4) \\
\hline Custo de Capital Próprio (Ke-y0) & 1,0000 & - & - & - & - \\
Transparência (Trnsp-y1) & $-0,05739$ & 1,0000 & - & - & - \\
Tamanho (Tam-y2) & $-0,01404$ & 0,527427 & 1,0000 & - & - \\
Endividamento (Endiv-y3) & 0,386594 & 0,004957 & $-0,0209$ & 1,0000 & - \\
Preço/valor patrimonial (BTM-y4) & 0,085842 & 0,033165 & $-0,02546$ & 0,074969 & 1,0000 \\
\hline
\end{tabular}

Como pode ser observado na tabela 9, as variáveis exógenas, em geral, não possuem alta correlação entre si, tratadas duas a duas. Com exceção da correlação observada entre as variáveis Transparência e Tamanho da empresa, que foi de 52,74\%. As demais variáveis apresentaram baixa correlação entre si e algumas inclusive correlação negativa.

Para testar estatisticamente o efeito da multicolinearidade, procedeu-se ao teste de Farrar e Glauber, indicado para regressões com três ou mais variáveis onde as correlações das variáveis independentes apresentam-se baixas. A estatística de teste, extraída de Corrar e Theóphilo (2004, p. 118) é a seguinte:

$$
\chi^{2}=-[n-1-1 / 6 \cdot(2 \cdot k+5)] \cdot \operatorname{Ln} \cdot \operatorname{det} .\left[\begin{array}{cccc}
1 & r_{12} & \ldots & r_{1 k} \\
r_{21} & 1 & \ldots & r_{2 k} \\
\cdot & & & \cdot \\
r_{k 1} & r_{k 2} & \ldots & 1
\end{array}\right]
$$

Onde: $n=$ tamanho da amostra;

$k=$ número de variáveis explicativas;

$L n=$ logaritmo neperiano

det $=$ determinante

$r_{i j}=$ coeficiente de correlação simples entre $x_{i}$ e $x_{j}$

A estatística de teste $\left(\chi^{2}\right.$ teste $)$ para as variáveis independentes mais altamente correlacionadas, Transparência (trnsp-y1) e Tamanho (tam-y2) é de 12,55 . O valor crítico $\left(\chi^{2}\right.$ crítico $)$ com 1 
grau de liberdade, $G L=k \cdot(k-1) / 2$, e nível de significância $95 \%$ é de 3,841, conforme tabela encontrada em Corrar e Theóphilo (2004, p. 485).

Como a estatística de teste $\chi^{2}$ teste $=12,55$ é maior que o valor crítico $\chi^{2}$ crítico $=3,841$, rejeitase, ao nível de 5\%, a hipótese nula de ausência de multicolinearidade. Portanto, existem evidências empíricas suficientes para apoiar a afirmativa de que as variáveis independentes Transparência e Tamanho da empresa possuem colinearidade significativa entre si.

O teste de Farrar e Clauber foi aplicado às demais variáveis. Para as variáveis Transparência (trnsp-y1) e Endividamento (Endiv-y3) estatística de teste $\chi^{2}$ teste $=0,0009458$, menor que o valor crítico $\chi^{2}$ crítico $=3,841$, fazendo com que deixe-se de rejeitar a hipótese nula de ausência de multicolinearidade.

Entre as variáveis Transparência (trnsp-y1) e Valor Patrimonial (BTM-y4) estatística de teste $\chi_{\text {teste }}^{2}=0,042371019$, menor que o valor crítico $\chi^{2}$ crítico $=3,841$, fazendo com que também deixe-se de rejeitar a hipótese nula de ausência de multicolinearidade.

Entre as variáveis Tamanho (tam-y2) e Endividamento (endiv-y3) estatística de teste $\chi^{2}$ teste $=$ 0,01681582 , menor que o valor crítico $\chi^{2}$ crítico $=3,841$, fazendo com que deixe-se de rejeitar a hipótese nula de ausência de multicolinearidade.

Entre as variáveis Tamanho (tam-y2) e Preço/Valor Patrimonial (BTM-y4) estatística de teste $\chi_{\text {teste }}^{2}=0,024968471$, menor que o valor crítico $\chi^{2}$ crítico $=3,841$, fazendo com que deixe-se mais uma vez de rejeitar a hipótese nula de ausência de multicolinearidade entre essas variáveis independentes.

Por fim, entre as variáveis Endividamento (endiv-y3) e Preço/Valor Patrimonial (BTM-y4) estatística de teste $\chi^{2}$ teste $=0,216992423$, menor que o valor crítico $\chi^{2}$ crítico $=3,841$, fazendo com que deixe-se vez de rejeitar a hipótese nula de ausência de multicolinearidade entre essas variáveis exógenas. 
Portanto, com exceção das variáveis independentes Transparência (trnsp-y1) e Tamanho (tamy2), para todas as outras variáveis tratadas duas a duas pode-se deixar de rejeitar a hipótese nula de ausência de multicolinearidade. Ou seja, as variáveis independentes do modelo de regressão, tratadas de maneira bivariada, não possuem multicolinearidade, com exceção das variáveis Transparência e Tamanho da Empresa.

\subsection{Análise da homocedasticidade e heterocedasticidade}

Uma primeira verificação feita a partir da análise dos gráficos de resíduos mostra que nem todos os resíduos dos coeficientes de regressão distribuem-se aleatoriamente ao longo da reta, como pode ser visualizado na figura 2.

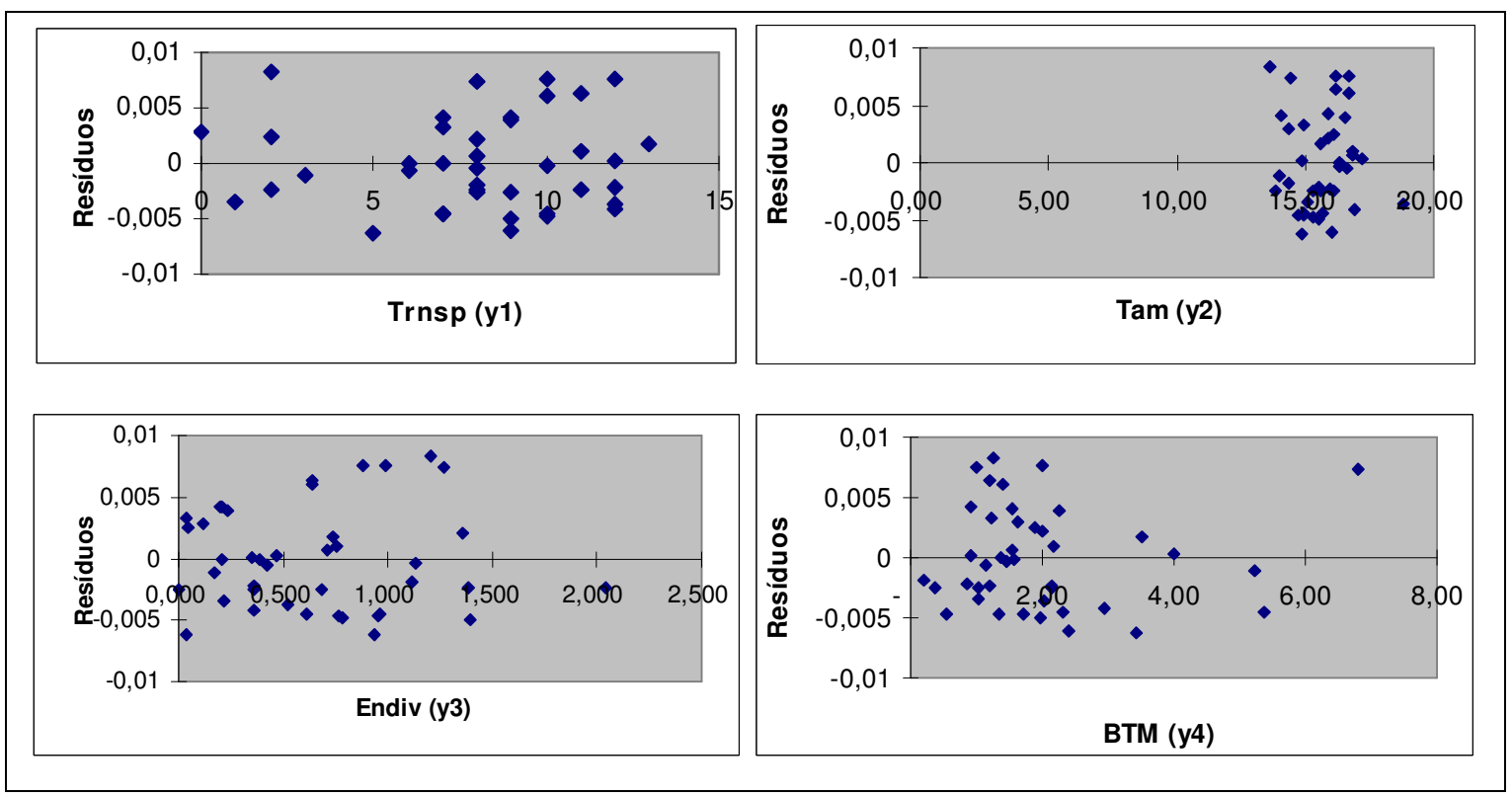

Figura 2 - Plotagem dos resíduos das variáveis independentes

Como observado acima, apenas nos resíduos da variável Transparência (Trnsp-y1) nota-se uma homogeneidade, o que indica uma presença de homocedasticidade. Já nas variáveis Tamanho (Tam-y2), Endividamento (Endiv-y3) e Índice book-to-market (BTM-y4), observase que a variabilidade dos resíduos cresce à medida que a variável $x$ cresce, caracterizando a presença de heterocedasticidade. 
A presença de heterocedasticidade nas variâncias dos resíduos das variáveis independentes indica uma violação do pressuposto da homocedasticidade, o que compromete a eficiência das estimativas do modelo de regressão utilizado neste estudo. Isso corrobora com o baixo poder de explicação das variáveis exógenas em relação ao custo do capital próprio. Para tornar mais válida essa afirmação, será realizado a seguir um teste para avaliar a autocorrelação.

\subsection{Teste de autocorrelação residual de Durbin-Watson}

Como este trabalho utilizou um modelo de regressão do Método dos Mínimos Quadrados para calcular as estimativas das variáveis dependentes e independentes, faz-se necessário a realização de um teste para verificar a existência de autocorrelação entre os resíduos. Isso será feito por meio do teste de Durbin-Watson, que possui a seguinte estatística de teste:

$$
D W=\frac{\sum\left(u_{t}-u_{t-1}\right)^{2}}{\sum u_{t}^{2}}
$$

Onde: $u_{t}=$ resíduo no período de tempo $t$;

$$
u_{t-1}=\text { resíduo no período de tempo } t-1 \text {. }
$$

Com base nessa formulação, a diferença ao quadrado dos resíduos (numerador da expressão 16) foi de 0,000804 e os resíduos ao quadrado (denominador da expressão 16) foi de 0,00069 . Dessa forma, a estatística de teste obtida foi de 1,165687.

A análise da Estatística de Durbin-Watson é feita a partir de uma Tabela de Valores Críticos, levando-se em consideração os limites críticos inferiores e superiores obtidos em Corrar e Theóphilo (2004, p. 489). Com base nessa tabela, para um nível de significância ( $\alpha$ ) de 5\%intervalo de confiança de $95 \%$-, número de variáveis independentes $(k-1)$ de 3 e tamanho da amostra de 41 empresas, obtém-se o limite crítico inferior $d_{L}=1,338$ e o limite crítico superior $d_{U}=1,659$. 
Como a estatística de teste de Durbin-Watson $(1,165687)$ é menor que o limite crítico inferior $d_{L}=1,338$, pode-se rejeitar a hipótese nula de ausência de autocorrelação residual, ou seja, como a estatística de teste é menor que o limite crítico inferior, há evidências empíricas suficientes para apoiar a afirmativa de que existe autocorrelação positiva entre os resíduos do modelo de regressão. Isso corrobora os resultados da análise de homocedasticidade e heterocedasticidade realizados anteriormente. 


\section{CONSIDERAÇÕES FINAIS}

A literatura que suporta a hipótese de que um maior nível de transparência na divulgação de informações (disclousure) impacta na redução do custo de capital próprio, apresentada neste trabalho, é embasada em duas teorias. A primeira pode ser encontrada nos trabalhos de Amihud e Mendelson (1986) e Diammond e Verrecchia (1991) e diz que uma maior transparência aumenta a liquidez das ações no mercado e, através disso, reduz o custo de capital pela redução dos custos de transação ou pelo aumento na demanda por títulos da empresa.

A segunda linha de pesquisa sugere que maior transparência pode reduzir o custo de capital pela redução do risco não diversificável de estimativa e tem como principais defensores autores como Klein e Bawa (1976), Barry e Brown (1985), Coles e Loewentein (1988), Handa e Linn (1993) e Coles et al. (1995).

Diversos trabalhos foram realizados, principalmente no exterior, no sentido de testar a hipótese de que maior nível de evidenciação tem como efeito uma redução no custo de captação de recursos pela empresa. Isso porque, é esperado que, ao divulgar informações relevantes, os investidores terão capacidade de melhor avaliar os investimentos que estão à sua disposição, reduzindo assim o risco de erro de estimativas de retorno do seu investimento na empresa e isso é capaz de reduzir o custo de capital.

Com base nisso, a investigação feita neste trabalho procurou verificar se o nível de transparência pode afetar o custo do capital próprio da empresas brasileiras, tendo como base o estudo uma regressão múltipla do tipo seção transversal entre a variável dependente custo de capital e a variável independente transparência. Além disso, foram utilizadas como variáveis de controle o tamanho da empresa (medida pelo logaritmo neperiano da receita bruta de vendas), o grau de endividamento (relação entre o Exigível Total e o Patrimônio Líquido) e a relação entre o preço da ação e o valor patrimonial da empresa (índice book-to-market).

$\mathrm{Na}$ estimativa do custo do capital próprio foi utilizado o modelo do Capital Asset Pricing Model - CAPM ajustado ao Brasil, conforme metodologia proposta por Assaf Neto (2003). Já 
variável transparência, foi determinada por meio da construção de um questionário composto de 14 questões, sendo parte extraída de Silveira (2004) e Alencar e Lopes (2005), que foram respondidas a partir da consulta dos sites das empresas da amostra.

$\mathrm{Na}$ análise de correlação de Pearson, as variáveis mais significativamente correlacionadas positivamente foram o Tamanho da Empresa e a Transparência, mostrando que empresas maiores são aquelas que mais evidenciam informações segundo o modelo utilizado para medir transparência desse estudo.

Porém, não houve correlação entre Custo de Capital Próprio e a proxy adotada para Transparência e o teste de hipóteses aplicado mostrou que a correlação apontada não pode ser considerada estatisticamente significativa. No entanto, para medir a relação de causa-efeito entre as variáveis relacionadas, foi feito o estudo da Regressão Linear Múltipla.

Para apoiar a utilização da regressão, foi realizado o teste Teste de normalidade KolmogorovSmirnov que forneceu evidências de que os resíduos das variáveis independentes utilizadas no modelo de regressão seguem uma distribuição normal de probabilidade, o que permitiu a utilização de uma Regressão Linear Múltipla pelo Método dos Mínimos Quadrados.

A regressão foi efetuada utilizando-se como variável dependente o Custo do Capital Próprio (Ke) e como variáveis independentes a proxy para transparência, o tamanho da empresa, o grau de endividamento e o índice book-to-market. Os resultados mostraram um baixo $R^{2}$, indicando que apenas $15,75 \%$ da proporção da variação total da variável dependente $(\mathrm{Ke})$ pode ser explicada pela variação das variáveis independentes. A análise do F de Significação impediu, porém, que a regressão fosse aceita como estatisticamente significativa.

Para testar estatisticamente o efeito da multicolinearidade, procedeu-se ao teste de Farrar e Glauber. Os resultados mostraram que, com exceção das variáveis independentes Transparência (trnsp-y1) e Tamanho (tam-y2), todas as outras variáveis tratadas duas a duas permitem deixar de rejeitar a hipótese nula de ausência de multicolinearidade. Ou seja, as variáveis independentes do modelo de regressão, tratadas de maneira bivariada, não possuem multicolinearidade, com exceção das variáveis Transparência e Tamanho da Empresa. 
Observou-se ainda a presença de heterocedasticidade nas variâncias dos resíduos das variáveis independentes, o que indica uma violação do pressuposto da homocedasticidade, fato que compromete a eficiência das estimativas do modelo de regressão utilizado neste estudo. Isso corrobora com o baixo poder de explicação das variáveis exógenas em relação ao custo do capital próprio.

A análise da autocorrelação entre os resíduos foi feita por meio do teste de Durbin-Watson, que permitiu rejeitar a hipótese nula de ausência de autocorrelação residual, fornecendo evidências empíricas suficientes para apoiar a afirmativa de que existe autocorrelação positiva entre os resíduos do modelo de regressão. Isso também corrobora os resultados da análise de homocedasticidade e heterocedasticidade.

Portanto, os resultados desse estudo não permitem afirmar que, no Brasil, no período estudado e com base nas variáveis analisadas, um maior grau de transparência impactou na redução significativa do custo de capital. Esse trabalho obteve a mesma conclusão de Alencar e Lopes (2005) em um estudo realizado no Brasil com uma amostra composta de 222 empresas, com dados contábeis de 31 de dezembro de 2003.

A exemplo dos autores, acredita-se que uma das principais limitações desse tipo de estudo é o fato de que as variáveis custo do capital próprio e nível de transparência não são medidas diretamente observáveis. Portanto, a qualidade das conclusões depende fica atrelada às escolhas das proxys adequadas para essas duas variáveis.

No âmbito internacional, os resultados desse estudo vão ao encontro das conclusões obtidas por Botosan e Plumlee (2002), que exploraram a associação entre o custo do capital próprio esperado e três tipos de transparência e, contrariando as expectativas prévias, as autoras também concluíram que maior transparência não estava associada com menor custo de capital próprio.

Uma consideração importante de ser feita é que o fato de algumas empresas obterem uma nota alta no questionário que buscou mensurar a transparência, não significa obrigatoriamente que mais informação seja sinônimo de boa informação. Mesmo que a empresa disponibilize, por exemplo, o relatório anual na internet, possua site bilíngüe e seção de relações com investidores, apresente demonstrativos em US-GAAP ou IAS-GAAP, não necessariamente 
implica que mais informação seja informação de qualidade. Uma quantidade maior de informação pode evidenciar inclusive aspectos negativos da empresa e que representariam, na verdade, um maior custo de captação devido a um eventual maior risco futuro.

No entanto, espera-se que esse trabalho tenha contribuído para a discussão sobre a relação entre transparência e custo de capital, ao apresentar pesquisas que representam o estado da arte sobre o tema e, principalmente, por fazer um estudo empírico cross section de um período recente (2005), utilizando proxies de estimação do custo de capital próprio e transparência, diferentes das pesquisas semelhantes realizadas no Brasil até então.

Como sugestão de trabalhos futuros poderiam ser desenvolvidos trabalhos que utilizassem um modelo mais robusto para servir como proxy da medida de transparência, do que a adotada neste trabalho, por meio de uma análise mais aprofundada de demonstrativos contábeis. Assim, ao invés de se trabalhar com uma grande base de dados, um estudo qualitativo com um pequeno número de empresas seria mais aconselhado do que uma análise quantitativa. 


\section{REFERÊNCIAS}

ALENCAR, Roberta Carvalho; LOPES, Alexsandro Broedel. Custo do Capital Próprio e Nível de Disclosure nas Empresas Brasileiras. In: CONGRESSO USP DE CONTROLADORIA E CONTABILIDADE, 5, 2005, São Paulo. Anais... Disponível em: $<$ http://www.congressoeac.locaweb.com.br/artigos52005/163.pdf>. Acesso em: 06/04/2006.

AMIHUD, Y.; MENDELSON, H. Asset pricing and the bid-ask spread. Journal of Financial Economics. v. 17, p. 223-249, 1986.

ANDRADE, Adriana de; ROSSETTI, José Paschoal. Governança Corporativa: fundamentos, desenvolvimento e tendências. São Paulo: Atlas, 2004.

ANDRADE, Adriana de; ROSSETTI, José Paschoal. Cresce adesão às boas práticas de governança corporativa. Valor Econômico. Valor On Line, 28/01/2005. Disponível em: <http://www.BOVESPA.com.br/pdf/Valor_280105.pdf>. Acesso em: 12/04/2006.

ASSAF NETO, Alexandre. Finanças Corporativas e Valor. São Paulo: Atlas, 2003.

ATKINSON, Anthony A. et al. Contabilidade Gerencial. São Paulo: Atlas, 2000.

BARRY, C. B.; BROWN, S. J. Differential Information and Security Market Equilibrium. Journal of Financial and Quantitative Analysis, v. 20, p. 407-422, 1985.

BOTOSAN, Christine A. Disclosure level and the cost of equity capital. The Accounting Review. CIDADE, v. 72, n. 3, p. 323-349, Jul. 1997.

BOTOSAN, Christine A.; PLUMLEE, Marlene A. A re-examination of disclosure level and the cost of Equity Capital. Journal of Accounting Research. CIDADE, v. 40, n. 1, p. 21-40, Mar. 2002.

BROWN, S. et al. Disclosure Quality and the Probability of informed trade. Working Paper, Emory University and Northwestern University, 2001.

BRUNI, Adriano Leal. Globalização financeira, eficiência informacional e custo de capital: uma análise das emissões de ADRs brasileiros no período 1992-2001. São Paulo, 2002. Tese (Doutorado em Administração) - Programa de Pós-Graduação em Administração, Departamento de Administração, Faculdade de Economia, Administração e Contabilidade da Universidade de São Paulo.

BUSHMAN Robert M. et al. What Determines Corporate Transparency? Journal of Accounting Research. CIDADE, v. 42, n. 2, p. 207-252, Mai. 2004. 
BUSHMAN, Robert M.; SMITH, Abbie J. Transparency, financial accounting information, and corporate governance. Economic Policy Review. New York, v. 9, n. 1, p. 65-87, Abr. 2003.

CHEN, Kevin C. W. et al. Disclosure, corporate governance, and the cost of equity capital: evidence from Asia's emerging markets. Working Paper Series, Social Science Research Network, 2003. Disponível em: $<$ http://papers.ssrn.com/sol3/papers.cfm?abstract_id=422000 >. Acesso em: 11/07/2006.

CLAESSENS, S. et al. Disentangling the Incentive and Entrenchment Effect of Large Shareholdings. The Journal of Finance, v. LVII, n. 6, p. 2741-2771, 2002.

COLES, J.; LOEWENSTEIN, U. Equilibrium pricing and portfolio composition in the presence of uncertain parameters. Journal of Financial Economics. p. 279-303, 1988

COLES, J. et al. On equilibrium pricing under parameter uncertainty. Journal of Financial and Quantitative Analysis. p. 347-364. September, 1995

CORRAR, L. J.; THEÓPHILO, C. R. Pesquisa operacional para decisão em contabilidade e administração: contabilometria. São Paulo: Atlas, 2004

DAMODARAN, Aswath. Avaliação de Investimentos: ferramentas e técnicas para a determinação do valor da qualquer ativo. Rio de Janeiro: Qualitymark, 2004.

DIAMOND, D.; VERRECCHIA, R. Disclosure, Liquidity, and the Cost of Capital. The Journal of Finance, v. 66, p. 1325-1355, 1991

EASLEY, David; O'HARA, Maureen. Information and the Cost of Capital. The Journal of Finance. CIDADE, v. 59, n. 4, p. 1553-1583, Ago.2004.

ECCLES, Robert G. et al. The Value Reporting Revolution: moving beyond the earnings game. PricewaterhouseCoopers. New York: John Wiley \& Sons, Inc., 2001.

FAMA, Eugene F. Efficient Capital Markets: a review of theory and empirical work. The Journal of Finance. CIDADE, v. 25, n. 2, Mai. 1970.

FLEURIET, Michel. A arte e a ciência das finanças: uma introdução ao mercado financeiro. Rio de Janeiro: Elsevier, 2004.

FRANCIS, Jere R. et al. Global evidence on incentives for voluntary accounting disclosures and the effect on cost of capital. Working Paper Series, Social Science Research Network, 2003. Disponível em: <http://papers.ssrn.com/sol3/papers.cfm?abstract_id=456900>. Acesso em: 11/07/2006. 
GITMAN, Lawrence J. Princípios de Administração Financeira. 7. ed. São Paulo: Harbra, 2002.

HANDA, P.; LINN, S. Arbitrage pricing with estimation risk. Journal of Financial Economics. p. 81-100, March, 1993.

HAIL, Luzi. The impact of voluntary corporate disclosures on the ex ante cost of capital for Swiss firms. Working Paper Series, Social Science Research Network, 2002. Disponível em: <http://papers.ssrn.com/sol3/papers.cfm?abstract_id=279276>. Acesso em: 12/07/2006.

HEALY, Paul M.; PALEPU, Krishna G. Information asymmetry, corporate disclosure, and the capital markets: a review of the empirical disclosure literature. Journal of Accounting and Economics. Holanda do Norte, v. 31, n. 1-3, p. 405-440, Set. 2001.

HEALY, Paul M.; PALEPU, Krishna G. The challenges of investor communication: the case of CUC International, Inc.. Journal of Accounting and Economics. Holanda do Norte, v. 38, n. 2, p. 111-140, Jun. 1995.

HENDRIKSEN, Eldon S.; VAN BREDA, Michael F. Teoria da Contabilidade. São Paulo: Atlas, 1999.

IBGC. Disponível em: < http://www.ibgc.org.br/ibConteudo.asp?IDArea=2>. Acesso em 04/04/2006.

IUDÍCIBUS, Sérgio de. Teoria da Contabilidade. 6. ed. São Paulo: Atlas, 2000.

JENSEN, Michael C.; MECKLING, William. Theory of the Firm: Managerial Behavior, Agency Costs and Ownership Structure. Journal of Financial Economics, v. 3, n. 4, p. 305360, Oct. 1976.

KAYO, Eduardo Kazuo. A estrutura de capital e o risco das empresas tangível e intangível-intensivas: uma contribuição ao estudo da valoração de empresas. São Paulo, 2002. Tese (Doutorado em Administração) - Programa de Pós-Graduação em Administração, Departamento de Administração, Faculdade de Economia, Administração e Contabilidade da Universidade de São Paulo.

KLEIN, R.; BAWA, V. The effect of estimation risk on optimal portfolio choice. Journal of Financial Economics. v. 3, p. 215-231, 1976.

LANZANA, Ana Paula. Relação entre disclosure e governança corporativa das empresas brasileiras. São Paulo, 2004. Dissertação (Mestrado em Administração) - Programa de PósGraduação em Administração, Departamento de Administração, Faculdade de Economia, Administração e Contabilidade da Universidade de São Paulo. 
LANG, M.; LUNDHOLM, R. Cross-sectional determinants of analysts ratings of corporate disclosure. Journal of Accounting Research, v. 31, p. 246-271, 1993.

LAPPONI, J. C. Estatística usando o Excel. Rio de Janeiro: Elsiever, 2005.

LIMA, Iran Siqueira et al. O custo de capitação e a governança corporativa. $17^{\circ}$ Congresso Brasileiro de Contabilidade. Anais... Brasília, Conselho Federal de Contabilidade, 2004.

LOPES, Alexsandro Broedel. The Value Relevance of Brazilian Accounting Numbers: an Empirical Investigation. Working Paper Series, Social Science Research Network, 2002. Disponível em: <http://papers.ssrn.com/sol3/papers.cfm?abstract_id=311459>. Acesso em: 30/04/2006.

MARTINS, Eliseu. Contabilidade de custos. 9 ed. São Paulo: Atlas, 2003.

MARTINS, Gilberto de Andrade. Manual para elaboração de monografias e dissertações. 2. ed. São Paulo: Atlas, 1994.

MCKINSEY \& Company e KORN FERRY International. Panorama de Governança Corporativa no Brasil. 2001. Disponível em: $<$ http://www.kornferry.com.br/upload/informacao/kf_mck_governan.pdf $>$. Acesso em: 12/04/2006.

MCKINSEY \& COMPANY. Global Investor Opinion Survey: Key Findings. McKinsey \& Company. Julho, 2002. Disponível em: $<\mathrm{http} / / /$ www.ifc.org/ifcext/cgf.nsf/AttachmentsByTitle/Survey_McKinsey_Investor_Oprin_S urvey_2002/\$FILE/Global+Investor+Opinion+Survey+2002.pdf>. Acesso em: 11/04/2006.

OCDE. Os Princípios da OCDE sobre o Governo das Sociedades. 2004. Disponível em: <http://www.oecd.org/dataoecd/1/42/33931148.pdf>. Acesso em 11/04/2006.

PEIXE, Franciane Cristina Darós. Novo Mercado: obstáculos e atrativos para as empresas do nível 1 de governança corporativa. São Paulo, 2003. Dissertação (Mestrado em Administração) - Programa de Pós-Graduação em Administração, Departamento de Administração, Faculdade de Economia, Administração e Contabilidade da Universidade de São Paulo.

ROSS, Stephen A. et al. Administração Financeira. São Paulo: Atlas, 1995.

SANVICENTE, Antonio Zoratto; MINARDI, Andrea M. A. Fonseca. Determinação do custo do capital do acionista no Brasil. Instituto Brasileiro de Mercado de Capitais: FinaceLab Working Paper - FLWP, n. 12, p. 1-8, Abr. 1999a. 
SANVICENTE, Antonio Zoratto; MINARDI, Andrea M. A. Fonseca. Problemas de estimação do custo de capital no Brasil. Instituto Brasileiro de Mercado de Capitais: FinaceLab Working Paper - FLWP, n. 9, p. 1-11, Jun. 1999b.

SCHADEWITZ, H. J.; BLEVINS, D. R. Major Determinants of Interim Disclosures in an emerging market. American Business Review, p. 261-280, 1995.

SILVEIRA, Alexandre Di Miceli da. Governança Corporativa e estrutura de propriedade: determinantes da relação com o desempenho das empresas no Brasil. São Paulo, 2004. Tese (Doutorado em Administração) - Programa de Pós-Graduação em Administração, Departamento de Administração, Faculdade de Economia, Administração e Contabilidade da Universidade de São Paulo.

SILVEIRA, Heber P. Internacionalização e custo de capital das empresas brasileiras: anáçise do impacto da emissão de american depositary receipts. São Paulo, 2003. Dissertação (Mestrado em Administração) - Programa de Pós-Graduação em Administração, Departamento de Administração, Faculdade de Economia, Administração e Contabilidade da Universidade de São Paulo.

TAPSCOTT, Don; TICOLL, David. A empresa transparente como a era da transparência revolucionará os negócios. São Paulo: M.Books, 2005.

TRIOLA, Mario F. Introdução à Estatística. 9. ed. Rio de Janeiro: LTC, 2005.

VERRECCHIA, Robert E. Essays on disclosure. Journal of Accounting and Economics. Holanda do Norte, v. 32, n. 1-3, p. 97-180, Dez. 2001.

WATTS, Ross L.; ZIMMERMAN, Jerold L. Positive Accounting Theory: A ten year perspective. The Accounting Review. CIDADE, v. 65, n. 1, p. 131-156, Jan. 1990. 